BONNEVILLE - HOOD RIVER VEGETATION MANAGEMENT

Environmental Assessment DOE/EA-1257 


\section{DISCLAIMER}

This report was prepared as an account of work sponsored by an agency of the United States Government. Neither the United States Government nor any agency thereof, nor any of their employees, make any warranty, express or implied, or assumes any legal liability or responsibility for the accuracy, completeness, or usefulness of any information, apparatus, product, or process disclosed, or represents that its use would not infringe privately owned rights. Reference herein to any specific commercial product, process, or service by trade name, trademark, manufacturer, or otherwise does not necessarily constitute or imply its endorsement, recommendation, or favoring by the United States Government or any agency thereof. The views and opinions of authors expressed herein do not necessarily state or reflect those of the United States Government or any agency thereof. 


\section{DISCLAIMER}

Portions of this document may be illegible in electronic image products. Images are produced from the best available original document. 


\section{Department of Energy \\ Bonneville Power Administration \\ P.O. Box 3621 \\ Portland, Oregon 97208-3621}

October 2, 1998

\section{To: People Interested in the Bonneville-Hood River Vegetation Management Project}

The Bonneville Power Administration (BPA) has made a decision on the Bonneville-Hood River Vegetation Management Project. The decision is explained below and in the three enclosed items: a Finding of No Significant Impact (FONSI), a Decision Notice, and a sheet listing changes that were made to the Environmental Assessment that was mailed to you earlier this summer.

Decision: BPA, in cooperation with the U.S. Forest Service, has decided to increase the variety of methods used to clear unwanted vegetation on about 20 miles of BPA transmission line rightof-way between Bonneville Dam and Hood River, Oregon. The right-of-way crosses federal, state, and private land in the Columbia Gorge National Scenic Area on the Oregon side of the Columbia River.

We will now use a system of zones within which one or more vegetation control methods may be used. The methods we use will depend on the environmental sensitivity of each zone. We will use a combination of manual, biological, and chemical techniques.

We will begin implementing these measures this fall.

Additional Copies: If you would like additional copies of any of the enclosed items, please call our toll-free document request line: 1-800-622-4520. Leave a message naming this project and giving your name and complete mailing address.

The information will also be available on the Internet, beginning October 15, at: www.efw.bpa.gov. Click on Policies, Strategies \& Analysis, click on Publications, and click on Bonneville-Hood River EA.

For More Information: If you need more information or have any questions, please call me toll-free at 1-800-282-3713. Thank you for your interest.

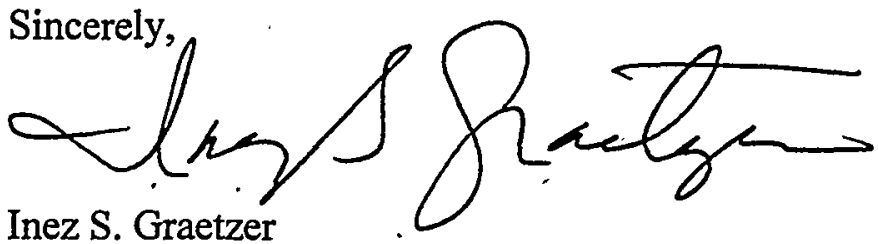

Environmental Project Manager

Enclosures (3) 
BONNEVILLE - HOOD RIVER VEGETATION MANAGEMENT

ENVIRONMENTAL ASSESSMENT

DOE/EA - 1257

August 1998

\section{ERRATA:}

Chapter 3, paragraph 3.2.3.2, under "Creation of the P Zone to Protect Sensitive Species", first paragraph, line 6. Change "Locations of sensitive plant species..." to read "Locations of sensitive/endemic species...."

3.3 Wildlife, page 19, Table 6. on the line for Bull Trout, strike out the word "Proposed" to update the status of that species.

errata.doc:9/18/98 


\section{0-01-P}

\section{DEPARTMENT OF ENERGY}

Bonneville Power Administration

Bonneville - Hood Ríver Vegetation Management Project

AGENCY: Bonneville Power Administration (BPA), Department of Energy (DOE). ACTION: Finding of No Significant Impact (FONSI)

SUMMARY: To maintain the reliability of its electrical system, BPA, in cooperation with the U.S. Forest Service, needs to expand the range of vegetation management options used to clear unwanted vegetation on about 20 miles of BPA transmission line right-of-way between Bonneville Dam and Hood River, Oregon, within the Columbia 'Gorge National Scenic Area (NSA). We propose to continue controlling undesirable vegetation using a program of Integrated Vegetation Managment (IVM) which includes manual, biological and chemical treatment methods. BPA has prepared an Environmental Assessment (EA) (DOE/EA-1257) evaluating the proposed project. Based on the analysis in the EA, BPA has determined that the proposed action is not a major Federal action significantly affecting the quality of the human environment, within the meaning of the National Environmental Policy Act (NEPA) of 1969. Therefore, the preparation of an Environmental Impact Statement (EIS) is not required and BPA is issuing this FONSI.

FOR FURTHER INFORMATION, CONTACT: Inez S. Graetzer, Bonneville Power Administration, P.O. Box 3621 (ECN-4), Portland, Oregon, 97208-3621, phone number 503-230-3786, fax number 503-230-5699. For additional copies of this FONSI, please call BPA's toll-free document request line: 800-622-4520.

Public Availability: This FONSI will be distributed to all persons and agencies known to be interested in or affected by the proposed action or alternatives. 
SUPPLEMENTARY INFORMATION: Trees and other tall-growing vegetation threaten system reliability by growing or falling into transmission lines. Shrubs and similar vegetation also threaten reliability by growing into access roads and keeping maintenance crews from needed access to transmission towers and lines. When hot ambient temperatures combine with large loads of transmitted electricity, conductors may sag into trees under high-voltage lines, resulting in fires, line outages, equipment shutdowns and disruptions of electrical power. Vegetation methods currently used in this area are inadequate to prevent long-term regrowth of tall-growing species. For example, handcutting with chainsaws, combined with characteristics of climate and vegetation in this area, have led to rapid re-sprouting of certain species and a dense growth that is difficult and dangerous for clearing personnel to maintain. Frequent and costly treatments are required. The proposed action allows BPA to use a program of Integrated Vegetation Management to encourage establishment of low-growing species, and prevent, where possible, the occurrence of tall-growing vegetation that would interfere with safe, reliable operation of the transmission line. Discrete vegetative management zones along the right-of-way identify the combination of techniques, including manual, biological and chemical methods that would effectively control vegetation and meet environmental constraints within those zones. Herbicide application would be done with hand pumped backpack sprayers. Application methods would include treating cut-stumps, basal application (spraying the lower 6-8 inches of the plant stem), and spot-foliar (product applied to a small amount of foliage of a specific plant). No broadcast or aerial application would occur.

The only alternative action identified is the status quo, where BPA would continue to manually cut tall-growing vegetation, encouraging the increase of tallgrowing vegetation and discouraging the establishment of low-growing species, with little opportunity to reach the goal of prevention. 
During the 30-day public comment period which ended September 14, 1998, one comment letter was received. The sender, Hood River County Weed \& Pest Division, noted that approval of the EA, and the opportunity to use integrated methods on federal lands under BPA lines... "would both benefit the Federal program and give a broad spectrum control program for all lands within Hood River County. Without the EA noxious weeds will be virtually impossible to control on Federal lands...." The Forest Service, NSA office asked that two items in the EA be corrected. (See the attached Errata Sheet for those changes to the EA.)

Potential impacts of the proposed action are: 1) changes in the vegetation composition on the right-of-way from tall-growing species to low-growing species; noxious weed control; low risk of impact to sensitive/endemic species.from trampling, felling trees, and herbicide application. 2) Temporary disturbance of wildlife every 2-3 years when workers are present; some herbicides may be hazardous or slightly toxic to some species. 3) Slight run-off and localized erosion would recur until low-growing vegetation is established. Slight sedimentation potential for water resources.

4) Moderate risk to workers of reproductive or general health effects from backpack sprayers using 3 of the 4 proposed herbicide formulations.

There are several reasons why these impacts would not be significant. First, changes in the vegetation from tall growing to natural low-growing species would allow BPA to visit the area less often, thereby reducing trampling, tree-felling and herbicide application, as fewer and fewer tall-growing vegetative species resprout. Noxious weed species along roadways would be treated, reducing the spread of noxious weeds. Fewer treatment visits by workers would result in less disturbance of wildlife, fewer intrusions into areas of sensitive/endemic plant species, and fewer occurrences of erosion off slopes when workers traverse them. Worker safety would increase with the use of herbicides, as the need for manual cutting is reduced, and the need for the herbicide treatment diminishes over time as natural low-growing vegetation becomes established. 
The 4 herbicides allowed for use on federal lands are of very low toxicity and do not bioaccumulate. Only workers licensed and trained in the safe handling of herbicides would apply the chemicals. The specific wildlife species which could be affected by the herbicides are not found in the right-of-way area. Buffer areas and seasonal treatment restrictions for sensitive/endemic plant habitats would be identified on zonal treatment maps for workers to follow. The low- volume and velocity of the backpack sprayers, and the specific nature of the application methods allow only the target species to be treated. No impacts are expected on cultural resources, air quality, water quality, visual and recreational resources, or the unique environmental resources of the Columbia River Gorge National Scenic Area.

Determination: Based on the information in the EA, as summarized here, BPA determines that the proposed action is not a major Federal action significantly affecting the quality of the human environment within the meaning of NEPA, 42 U.S.C. 4321 et seq. Therefore, an EIS will not be prepared and BPA is issuing this FONSI.

Issued in Portland, Oregon, on September 24, 1998.

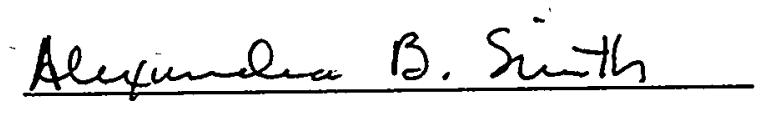

Alexandra B. Smith, Vice President, Environment, Fish and Wildlife Group 


\title{
DECISION NOTICE
}

\section{Bonneville - Hood River Vegetation Management Project}

\author{
U.S. Department of Energy \\ Bonneville Power Administration
}

\author{
U.S. Department of Agriculture Forest Service \\ Columbia River Gorge National Scenic Area
}

\section{INTRODUCTION:}

The Bonneville Power Administration (BPA) manages its transmission line rights-of-way (ROW) in the Columbia River Gorge in accordance with ROW Management Plans developed in cooperation with the U.S. Forest Service (USFS). These ROW Management Plans are a requirement of the 1974 Memorandum of Understanding (MOU) between the two agencies. National Environmental Policy Act (42 USC 4321 et seq.) (NEPA) documents are also required to address the impacts of maintenance processes identified in ROW Management Plans. Initial ROW Management Plans were affected in 1984, when herbicide use was eliminated as a result of the United States District Court for the District of Oregon's injunction on the use of herbicides within USFS Region Six (Pacific Northwest Region). This injunction was lifted in 1989 after the Pacific Northwest Region completed a final Environmental Impact Statement (EIS) on Managing Competing and Unwanted Vegetation, issued a Record of Decision (ROD), and negotiated a Mediated Agreement with the lawsuit plaintiffs and the court. This Mediated Agreement now determines the procedures to be used by any ROW vegetation management performed on federal lands where herbicide use is proposed.

Between 1984 and 1996, BPA did not use herbicides for vegetation management on federal lands in the Columbia River Gorge National Scenic Area (NSA), even though the CRGNSA. Act specifically exempts BPA transmission line maintenance from its provisions. (The Act also exempts transmission maintenance from the standards and guidelines established by the implementing NSA management plan.) Consequently, mechanical and hand-clearing methods were used, resulting in increased tall-growing vegetation density, more frequent maintenance attention, increased disturbance to wildlife, steep slopes, sensitive/endemic plant species habitats, increase in noxious weeds along roadways, and the increased risk of worker accidents because of vegetation density and recurring treatments. As a result, BPA's ROW vegetation management has become increasingly more difficult and costly.

In March 1996, in response to the need to expand the range of vegetation management options in the NSA, BPA, its consultants, and the USFS (NSA) completed an evaluation of current vegetation management practices. They then developed management strategies for the NSA that would not adversely affect sensitive resources. Those strategies, which include combinations of manual, mechanical, biological and chemical treatments, were designed to be suitable for BPA's transmission rights-of-way throughout the NSA. This new approach was applied to two transmission ROWs on the north side of the NSA, near Carson, Washington and evaluated in an 
Environmental Assessment (EA) in 1996. Based on that site-specific environmental analysis, the vegetation management plan for those segments of transmission line was updated. An Integrated Vegetation Management (IVM) approach, including herbicide application, was used on these corridor segments (approximately $10 \mathrm{mi}$.) in the summer of 1997.

In 1997, BPA and the USFS began to study BPA's proposal to use an Irtegrated Vegetation Management approach, including herbicide application, along 20 miles of right-of-way for the Bonneville - Hood River 115-kilovolt transmission line. The right-of-way is located on the south side of the river, between Bonneville Dam and Hood River, Oregon, within the NSA.

BPA assumed the lead agency role and completed an Environmental Assessment (EA) on the proposed plan; the USFS served as a cooperating agency. After public scoping, the EA was prepared and issued for public review on August 12, 1998. Comments were accepted through September 14, 1998. A Finding of No Significant Impact (FONSI) was prepared, reflecting responses to these comments. The FONSI was signed by BPA on September 24, 1998; it is part of the official Decision Record. This Decision Notice reflects the final decision made by both BPA and the USFS (NSA) on the proposed action. The EA preparation team consisted of interdisciplinary staff from both the USFS (NSA) and BPA.

\section{DECISION AND RATIONALE FOR DECISION:}

After review of the EA and public comments, it is our decision to select and implement the Proposed Action Alternative as described in the Bonneville - Hood River Vegetation Management EA, along with all associated mitigation measures defined in Chapter 3 . This includes the use of chemical, as well as manual and biological methods, in a process called Integrated Vegetation Management (IVM). Tall-growing vegetation is first removed using hand-clearing and herbicide methods; phased herbicide applications follow when vegetation is young. Vegetation management prescriptions have been identified and mapped to avoid impacts on sensitive resources. This EA will be used to update BPA's ROW Management Plan for the Bonneville Hood River ROW using the IVM approach: All chemicals that would be used are approved by the Environmental Protection Agency (EPA), and are consistent with the USFS EIS, the associated Mediated Agreement, and the standards and guidelines of the Northwest Forest Plan.

We agree that the selective and controlled use of herbicides in combination with hand-clearing and biological techniques will best achieve the goal of converting rights-of-way to low-growing manageable vegetation communities, while minimizing impacts on sensitive resources. The proposed action should result in less disturbance to wildlife, steep slopes, and sensitive/endemic plant species habitats because of less frequent maintenance activity. The proposal should help to control noxious weeds and assist in reducing their spread. It should also reduce the maintenance costs and increase worker safety as a result of less hand clearing and fewer recurring treatments. Over time, this integrated vegetation management approach will also enhance response to the objectives of the NSA Act. 


\section{MITIGATION AND MONITORING:}

The EA lists mitigation measures identified by the interdisciplinary team for avoiding, reducing, or eliminating environmental impacts associated with the implementation of IVM. BPA commits to carry out the mitigation as defined. The treatment methods and resource protection measures will be integrated into BPA vegetation management contractual documents, and noted on plan and profile maps or photomaps used by maintenance personnel; or contractual workers. This will help insure that methods proposed are understood and carried out.

BPA also commits to conducting an Environmental Appraisal/Audit to monitor the results and success of the IVM, not only to avoid environmental impacts on sensitive resources, but also to document cost-effectiveness and public response. The appraisal/audit will also evaluate and identify further improvement needs.

\section{OTHER ALTERNATIVES CONSDERED:}

Status Quo Alternative. Under this alternative BPA would continue the current practice of using manual and biological methods for controlling undesirable vegetation. Chemicals (herbicides) would not be used to control undesirable vegetation. The disadvantages of this alternative are that continued manual cutting of tall-growing vegetation encourages the increase of tall-growing vegetation, and discourages the establishment of low-growing species, allowing little opportunity to reach the goal of prevention. Transmission system reliability would continue to be threatened, and maintenance costs would continue to escalate with more frequent manual treatments.

Increasing visits to the area by workers would result in increased disturbance of wildlife, increased intrusions into areas of sensitive/endemic plant species, and increasing erosion off slopes as workers traverse them. The risk of worker accidents from manual methods continues or increases as vegetation from repeated manual cuttings becomes more dense, requiring more frequent cutting. Noxious weeds would continue to spread on the right-of-way.

\section{PUBLIC INVOLVEMENT:}

On October 27, 1997, a scoping letter was sent to adjacent landowners, interested individuals, agencies, and organizations on the public mailing list of over 200 addressees. In addition, a scoping notice was published in The Oregonian on October 29, 1996, announcing the 30-day scoping period and inviting public comments through November 26, 1997. Comments received ranged from requests for landowner notification of activities so as not to affect a recreational business, to concerns about protection of water quality, and proximity of herbicide use to agricultural enterprises. The comments were used to define the scope of the EA being prepared.

The EA was sent out on August 5, 1998 for a 30-day public review. A Notice of Availability for public comment on the EA was published in The Oregonian on August 12, 1998. The comment period closed on September 14, 1998 (36 CFR 15.6(a)). One comment letter was received. The commentor supported the IVM approach in regards to noxious weed control on federal lands. The comment is noted on page 3 of the FONSI. The USFS (NSA) asked that 2 corrections be made to the EA. An Errata Sheet to the EA was prepared, giving the locations of those two corrections. 


\section{FINDING OF NO SIGNIFICANT IMPACT:}

As federal lead agency, BPA was responsible for preparing the Finding of No Significant Impact (FONSI) in accordance with the NEPA Implementing Regulation of the Council on Environmental Quality ( 40 CFR Parts 1500 - 1508) and the Department of Energy (10 CFR 1021). The FONSI was signed by the BPA Vice President, Environment, Fish \& Wildlife Group, Alexandra B. Smith, on September 24, 1998.

\section{OTHER FINDINGS:}

We find that the Bonneville - Hood River Vegetation Manàgement EA and FONSI are consistent with the 1974 USFS/BPA MOU, the requirements of the Mediated Agreement, and the Pacific Northwest Forest Plan: No conflicts have been found with the consultation, review, and permit requirements mandated by other environmental regulations.

\section{APPEAL RIGHTS:}

This decision is not subject to appeal pursuant to 36 CFR 215.8. During the comment period there was no expression of interest received regarding the need to modify the proposed action.

\section{IMPLEMENTATION:}

Vegetation management prescriptions, as defined in the Bonneville - Hood River Vegetation Management EA, can be carried out immediately following publication of the Legal Notice in The Oregonian, Portland, OR.

\section{CONTACTS:}

For further information concerning the implementation of this project contact: Ed Medina or Art Guertin, Columbia River Gorge National Scenic Area Office, 902. Wasco Avenue, Suite 200, Hood River, Oregon (541-386-2333); or Libby Johnson, Bonneville Power Administration, Transmission Line Maintenance Natural Resource Specialist, 3920 Columbia View Drive East, The Dalles, Oregon , (541-296-8905). Copies of the EA, Errata sheet, and Finding of No Significant Impact can be obtained from the BPA document request line 1-800-622-4520, or by calling the National Scenic Area Office at 541-386-2333.

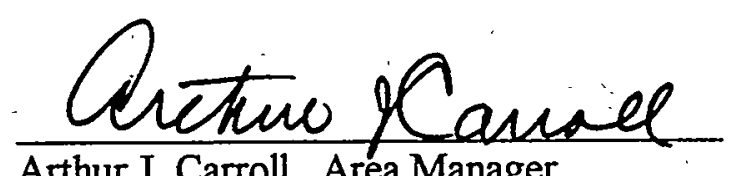

Arthur J. Carroll, Area Manager Columbia River Gorge.NSSA U.S. Department of Agriculture Forest Service<smiles>[R6]C(C)C(C)C(C)C</smiles>

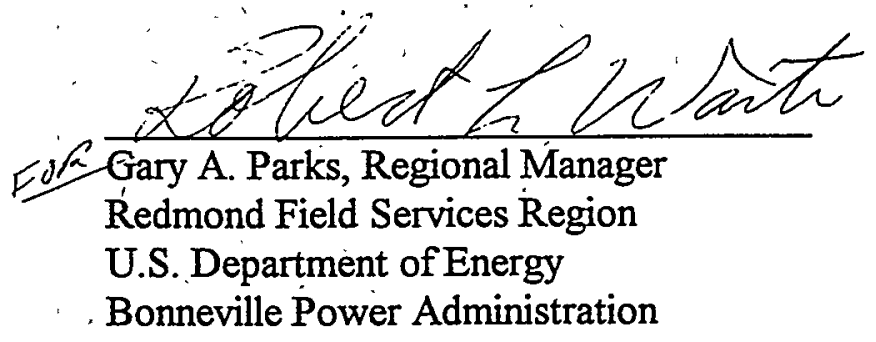

Date: $9 / 28 / 92$ 


\section{Table of Contents}

CHAPTER 1 PURPOSE OF AND NEED FOR ACTION ..................................... 1

1.1 Underlying Need for Action

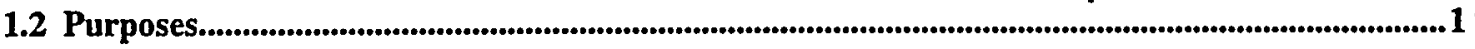

1.3 Background: History and Legal Requirements ..................................................................................3

1.4 Decisions To Be Made ......................................................................................................................................4

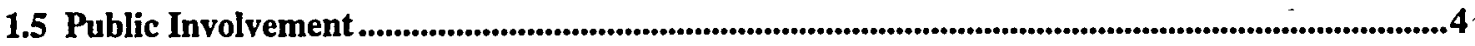

CHAPTER 2 PROPOSED ACTION AND ALTERNATIVES.............................. 6

2.1 Proposed Action: Integrated Vegetation Management (IVM) with Herbicides .........................6

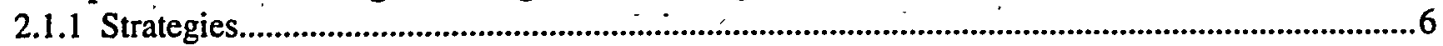

2.1.2 Vegetation Management Techniques ....................................................................................................

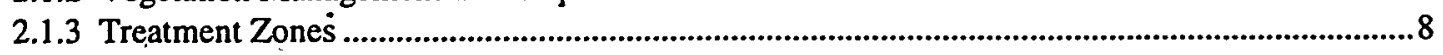

2.2 Status Quo Alternative ............................................................................................................................8

2.3 Options Eliminated from Detailed Evaluation ................................................................................................8

2.3.1 Mechanical Techniques .............................................................................................................8

2.3.2 Prescribed Burning ...........................................................................................................................

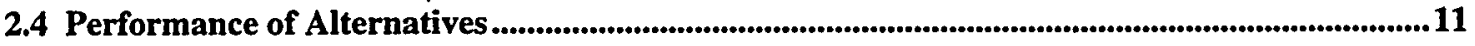

CHAPTER 3 AFFECTED ENVIRONMENT AND ENVIRONMENTAL

CONSEQUENCES .............................................................................................. 12

3.1 Study Area

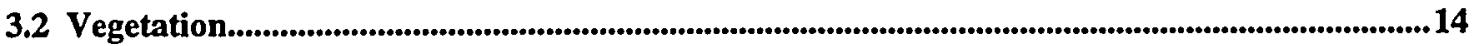

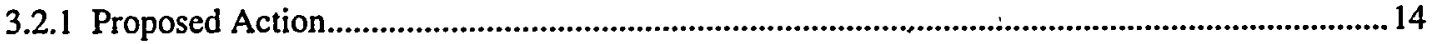

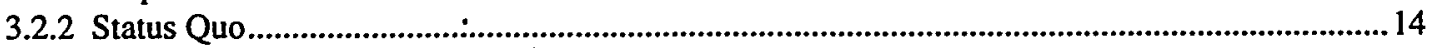

3.2.3 Endangered, Threatened, and Sensitive Plants........................................................................ 15

3.3 Wildlife

3.3.1 Proposed Action................................................................................................................ 19

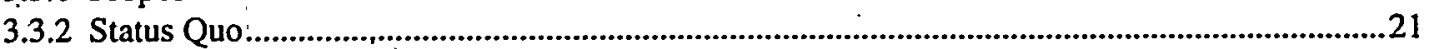

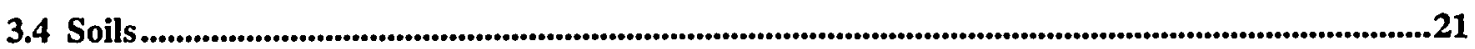

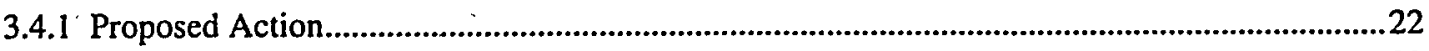

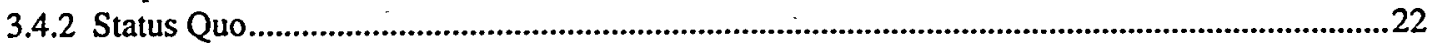




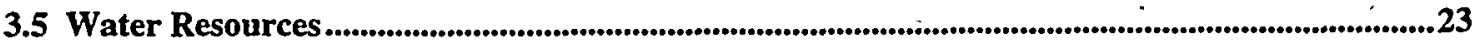

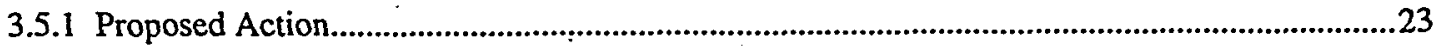

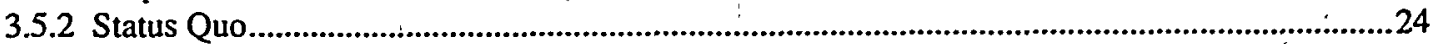

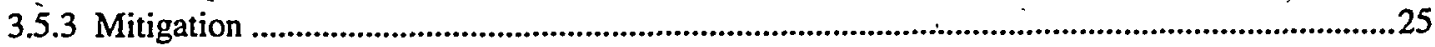

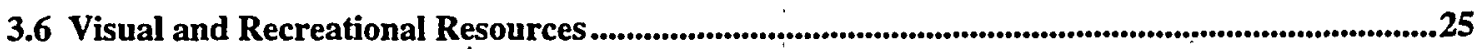

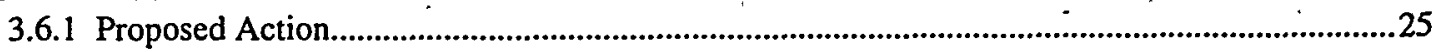

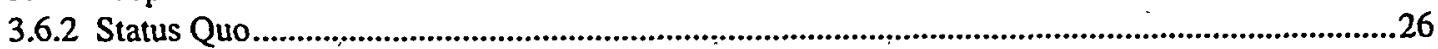

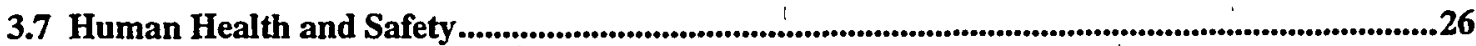

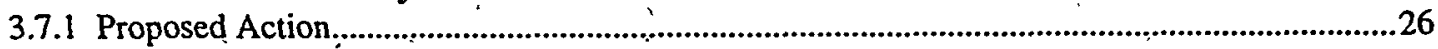

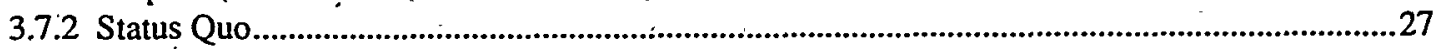

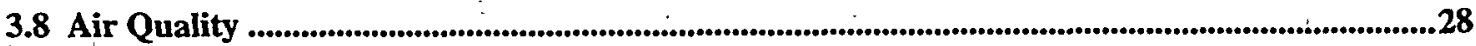

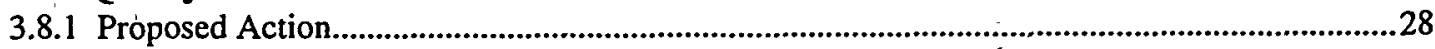

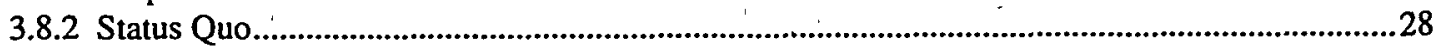

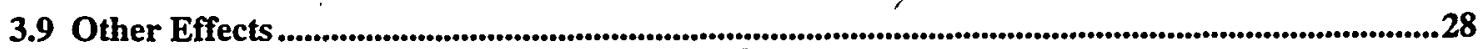

\section{CHAPTER 4 CONSULTATION, REVIEW, AND PERMIT REQUIREMENTS... 29}

National Environmental Policy................................................................................................29

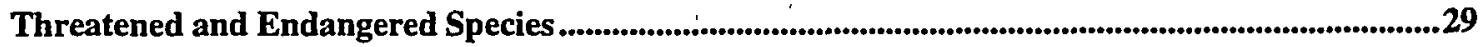

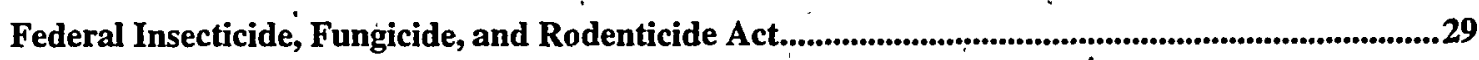

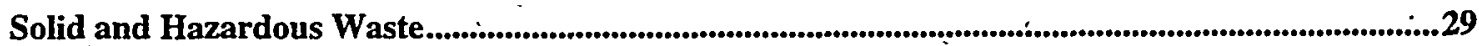

Federal, State, Areawide and Local Plan and Program Consistency............................................29

Floodplains and Wetlands, Safe Drinking Water Act ..........................................................30

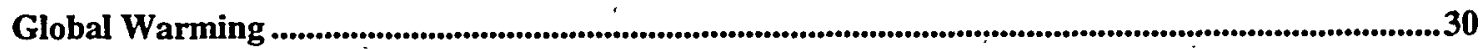

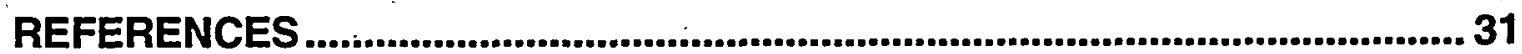

PREPARERS AND CONTRIBUTORS ................................................................ 33

APPENDIX A PUBLIC COMMENTS....................................................................A

APPENDIX B HERBICIDE INFORMATION PROFILES ....................................... 


\section{CHAPTER 1 PURPOSE OF AND NEED FOR ACTION.}

\subsection{Underlying Need for Action}

To maintain the reliability of its electrical system, Bonneville Power Administration (BPA) needs to expand the range of vegetation management options for about 30 kilometers (19 miles) of a transmission line right-of-way between Bonneville Dam and Hood River, Oregon. Trees and other tall-growing vegetation threaten system reliability by growing or falling into transmission lines. Shrubs and similar vegetation also threaten reliability by growing into access roads and keeping maintenance crews from needed access to transmission towers and lines. When hot ambient temperatures combine with large loads of transmitted electricity, conductors may sag into trees under high-voltage lines, resulting in fires, line outages, equipment shutdowns and disruptions of electrical power.

The Bonneville-Hood River 115-kV transmission line right-of-way is within the Columbia Gorge National Scenic Area (NSA) (Figure 1). The Gorge NSA's founding legislation contained an exemption clause that allowed BPA to continue its then-current maintenance activities (Columbia River Gorge National Scenic Area Act (CRGNSA Act), P.L. 99-66, November 17, 1986). However, BPA was not using herbicides at that time. Vegetation management methods currently used in this area are inadequate to prevent long-term regrowth of tall-growing species. For example, hand-cutting with chainsaws, combined with the characteristics of climate and vegetation in this area, have led to rapid re-sprouting of certain species and a dense growth that is difficult and dangerous for clearing personnel to maintain. Frequent and costly treatments are required.

\subsection{Purposes}

In meeting the underlying need, BPA wants to achieve the following purposes, or goals:

- Comply with national and regional policies and mandates, including the United States District Court for the District of Oregon's Mediated Agreement on the use of herbicides in the U.S. Forest Service (USFS) Pacific Northwest Region (Region Six), the Final Environmental Impact Statement (FEIS) for Managing Competing and Unwanted Vegetation (USDA Forest Service 1988), and the CRGNSA Act.

- Protect the natural and human environment from adverse impact.

- Maintain electrical reliability of the Federal Columbia River Transmission System (FCRTS).

- Provide for administrative efficiency and cost effectiveness. 


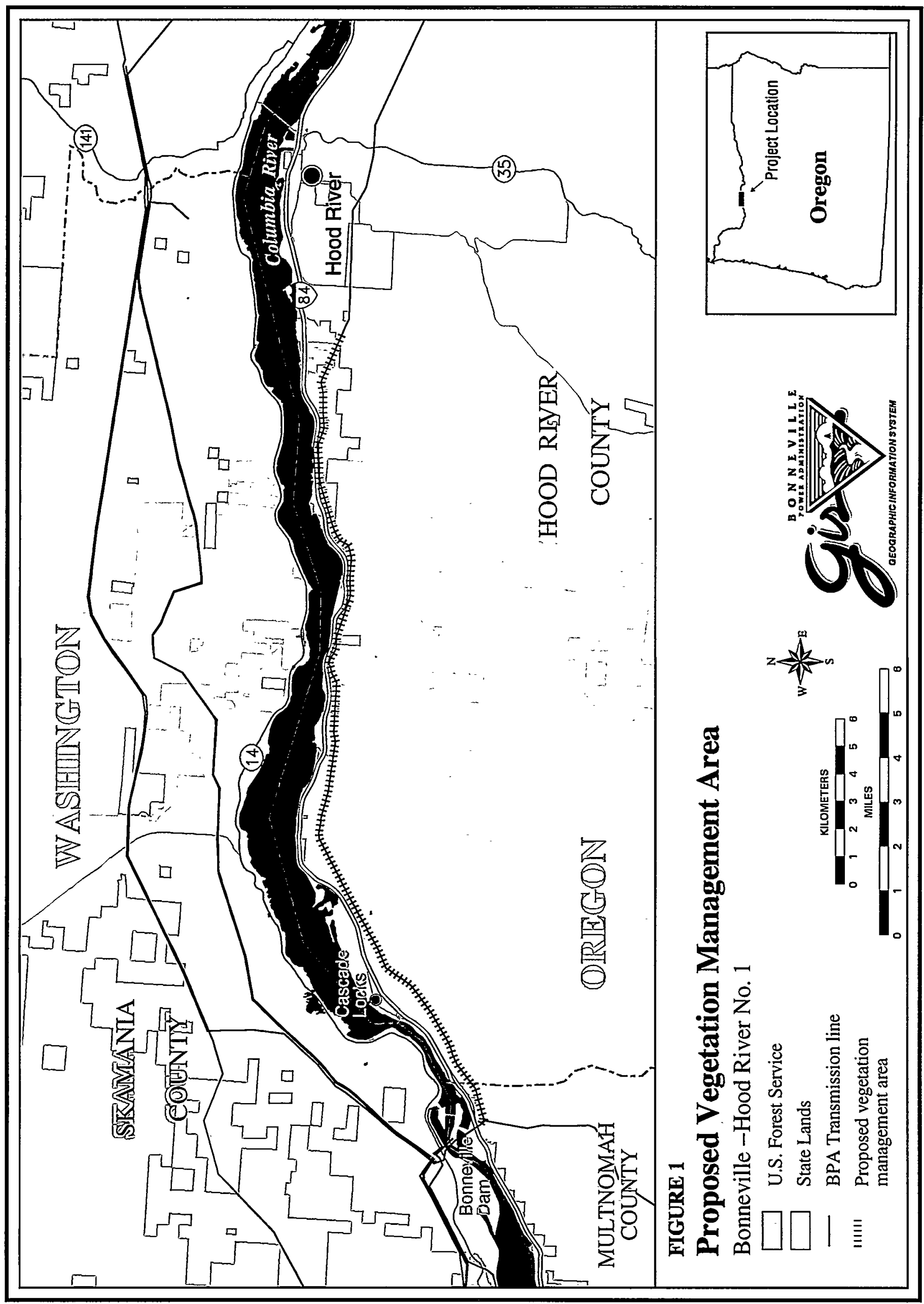




\subsection{Background: History and Legal Requirements}

The Bonneville-Hood River transmission line right-of-way crosses federal, state, city, and private lands in the Columbia Gorge NSA on the Oregon side of the Columbia River (Figure 1). Depending on who owns or manages the land, vegetation on BPA's right-ofway may be managed in different ways.

Vegetation Management on USFS Land. BPA manages its transmission line rights-ofway in the Columbia Gorge in accordance with Right-of-way Management Plans developed in cooperation with the USFS. These plans are required by the 1974 Memorandum of Understanding (MOU) between the two agencies. National Environmental Policy Act (NEPA) documents must also evaluate the impacts of maintenance pròcesses identified in Right-of-way Management Plans. In 1983, initial Management Plans were affected when herbicide use was eliminated as a result of the U.S. District Court for the District of Oregon's injunction on the use of herbicides within USFS Region Six (Northwest Coalition for Alternatives to Pesticides v. Yeutter, supra.). This injunction was lifted in 1989 after USFS Region Six completed a final Environmental Impact Statement (EIS) on Managing Competing and Unwanted Vegetation, issued a Record of Decision (ROD), and negotiated a Mediated Agreement with the lawsuit plaintiffs and the court. This Mediated Agreement now determines the procedures to be used when any vegetation management program on USFS lands proposes use of herbicides. In 1993, the USFS issued guidelines for complying with the terms of that agreement by requiring site-specific analysis and public involvement for most vegetative management activities, including those on rights-of-way.

Between 1984 and 1996, BPA did not use herbicides for vegetation management on federal lands in the NSA, even though the CRGNSA Act specifically exempts BPA transmission line maintenance from its provisions. (The Act also exempts transmission maintenance from the standards and guidelines established by the implementing NSA management plan.) Mechanical and hand-clearing methods have been used to remove or control undesirable vegetation (defined as tall-growing vegetation threatening to grow or fall into transmission lines, vegetation bordering access roads, and noxious weeds or other pest species). During this period, cut deciduous trees have re-sprouted, producing even more dense vegetation; conifer seedlings have re-invaded cleared areas; maintenance frequency has increased; and BPA has been unable to establish more desirable low-growing species, which would reduce the cost and environmental impacts of vegetation management activities.

Prototype Study. In March 1996, in response to the need to expand the range of vegetation management options in the NSA, BPA, its consultants, and the USFS (NSA) completed an evaluation of current vegetation management practices. They then developed management strategies for the NSA that would not adversely affect sensitive resources (David Evans and Associates, Inc., 1996). Those strategies, which include combinations of manual, mechanical, biological and chemical treatments, were designed to be suitable for BPA's transmission rights-of-way throughout the NSA. They were first proposed for use on the Hanford-Ostrander and North Bonneville-Midway corridors and 
were evaluated in BPA's Columbia River Gorge Vegetation Management Final Environmental Assessment (DOE/EA-1 162), September 1996.

Based on that site-specific environmental analysis, the vegetation management plan for segments of the Hanford-Ostrander corridor and North-Bonneville-Midway corridor was updated. An Integrated Vegetation Management (IVM) approach, including herbicide application, was used on these corridor segments (approximately. $16 \mathrm{~km}$ [10 mi]) on the Washington side of the NSA in the summer of 1997.

Vegetation Management on State, City and Private Land in the NSA. On BPA rights-of-way crossing state, city and private land in the NSA (as elsewhere in BPA's service area), any vegetation management methods proposed, including herbicides, are governed by federal, state and EPA regulations and by BPA's easements rights.

Generally, BPA notifies private property owners before vegetation management activities begin on their land. At that time, concerns about the vegetation control methods proposed for the property, including herbicides, are discussed and resolved.

\subsection{Decisions To Be Made}

BPA Decision: Whether to change its yegetation management program for approximately $30 \mathrm{~km}(19 \mathrm{mi})$ of the Bonneville-Hood River transmission line between Bonneville Dam and Hood River, Oregon (within the boundaries of the NSA).

Before making the decision, BPA, as a federal agency, must comply with requirements of the National Environmental Policy Act (NEPA) to analyze the environmental effects of proposed federal actions.

USFS Decision: Whether to allow modification of BPA's existing Right-of-way Management Plan (1982) for the Bonneville-Hood River transmission line in the NSA.

The USFS decision must be made in compliance with NEPA and with the Mediated Agreement.

This Environmental Assessment (EA) and its associated public involvement program are designed to meet requirements for both agencies.

\subsection{Public Involvement}

On October 27, 1997, a letter was sent to area landowners and others potentially interested in the project, and a public notice was published in The Oregonian newspaper. The letter and notice announced the proposal and initiated the scoping period. (Scoping is the gathering of topics and issues for consideration in an environmental study.) Comments were accepted through November 26; 1997. Three comments were received (see Appendix A). Commenters' concerns are summarized here, followed by a response or a listing of where in the EA the issue is addressed.

1) One commenter was concerned that herbicides would migrate hydraulically to adjacent private property which is used for a small organic market garden; she asked to extend her 5-year-old agreement with BPA that chemicals not be applied in the 
right-of-way that crosses above the property on state and private land. (Response: Sections 3.4.1 and 3.5.1 discuss the persistence and migration of herbicides in soils and water. Given the properties of the herbicides proposed for use, the methods of application, and the soil and water resources in the area, herbicides are not expected to contaminate the organic garden. However, because of the nature of the commercial operation and the request to extend the agreement, BPA will continue to honor the property owner's request for no chemical application on the right-of-way adjacent to the market garden property.

2) One commenter was concerned that chemicals could wash into a small, intermittent stream that feeds a lake on non-adjacent private land. (Response: The source of the intermittent stream is over 30 meters (100 feet) north of the right-of-way, and the steam, when flowing, does not cross any part of the right-of-way. As stated in the previous response, sections 3.4.1 and 3.5.1 indicate that, given the properties of the herbicides proposed for use, the type of specific application methods to be used, and the soil and water resources in the area, the herbicides would not likely contaminate the small, intermittent stream that feeds the lake.)

3) One property owner suggested that crews working on the right-of-way would detract from the backcountry horseback riding experience for commercial clients and requested notification of when and where vegetation management activities would occur on the right-of-way, so riders could avoid the area. (Response: Notification will be provided.) 


\section{CHAPTER 2 PROPOSED ACTION AND ALTERNATIVES}

\subsection{Proposed Action: Integrated Vegetation Management (IVM) with Herbicides}

BPA proposes to continue controlling undesirable vegetation on $30 \mathrm{~km}(19 \mathrm{mi})$ of its Bonneville-Hood River transmission line right-of-way using a program of Integrated Vegetation Management (IVM). This program is based on a method developed by BPA, consultants and the USFS with the long-term objective of preventing, where possible, the growth of unwanted vegetation (David Evans \& Associates, 1996). It identifies discrete vegetative management zones in the Columbia Gorge NSA and the combination of techniques, including manual, biological and chemical methods, that would effectively control vegetation and meet environmental constraints within those zones.

The cost of manually clearing the right-of-way of tall-growing vegetation in 1997 was $\$ 200$ - $\$ 300 /$ acre. The proposed program would increase the cost to $\$ 300$ - $\$ 400 / \mathrm{acre}$, because crews would use both manual cutting and herbicide methods in the first two years to bring vegetation to manageable levels. Costs would decline significantly from $\$ 400 /$ acre for follow-up treatments because labor costs would be lower-herbicide application is considered a safer activity than using chainsaws and thus costs less--and treatments would be needed less often to keep the right-of-way free of tall-growing brush.

The proposed action focuses, with a few exceptions, on the publicly owned portions of the Bonneville-Hood River right-of-way within the Columbia Gorge NSA (Figure 1). There are two main reasons for this focus: Over the last few years, vegetation management standards have changed on USFS administered lands and BPA must meet those new standards (see section 1.3), whereas BPA's individually negotiated maintenance agreements with private landowners would remain in place unless the landowner and BPA agree on a need to change them.

The remainder of section 2.1 describes the proposed vegetation management strategies, methods and treatment zones for the Bonneville-Hood River right-of-way. Chapter 3 describes the process and criteria used to define the zones and their techniques.

\subsubsection{Strategies}

The Mediated Agreement defines five alternative strategies that should be considered when analyzing vegetation management proposals: prevention (the preferred strategy as documented in the USFS 1988 FEIS Record of Decision), correction, early treatment, maintenance, and no action. The proposal incorporates four of those strategies.

Prevention. The goal of IVM is to prevent, where possible, the occurrence of tallgrowing vegetation that would interfere with the safe, reliable operation of the transmission line by encouraging establishment of low-growing species.

Correction. The proposal recognizes that vegetation on some parts of the right-of-way is at or near the point of threatening the reliability of the transmission system. In those 
areas; corrective action would be taken to eliminate tall trees and shrubs and provide the environment in which low-growing species can compete and thrive.

Early Treatment. In some parts of the right-of-way, low-growing vegetation already has been established and needs only limited treatment to maintain that condition. The proposal recognizes, however, that due to the characteristics of the right-of-way, prevention may not be an attainable goal. Because the right-of-way-is a long, narrow strip of land where the vegetation is different from that of most of the surrounding land, conifers and other tall-growing species from the adjacent forest may seed themselves on the right-of-way, especially where low-growing vegetation has not become established. Thus regular early treatment would be needed to prevent tall-growing species from taking hold. BPA may reseed or plant a few areas, as appropriate, to prevent repeat treatments.

No Action. On some portions of the right-of-way, vegetation control is unnecessary because the line spans steep canyons so high above the trees that there is little danger they will grow into the conductors and threaten system operations. These areas are defined by the STC zone (see section 2.1.3). If an individual tree should grow close to a conductor, the tree would be removed.

In general, BPA proposes to use the correction strategy for most of the right-of-way (except in the STC zones) for about 1 - 3 years. Later, depending on vegetation regrowth, the program would focus on early treatment, with the ultimate goal of prevention.

\subsubsection{Vegetation Management Techniques}

BPA proposes to use the following techniques to control vegetation on the BonnevilleHood River right-of-way. They would be used in various combinations, depending on the vegetative management zone (see section 2.1.3).

Manual. Hand-pull target plants or use hand-operated tools, including chain saws, to cut herbaceous or woody target species.

Biological. Two techniques may be used:

- Encourage low-growing species to dominate the vegetation community, where necessary, by eliminating the taller trees or by reseeding cleared areas with grasses and forbs compatible with local vegetation.

- Introduce species-specific parasites such as the cinnabar moth to control tansy ragwort, a noxious weed. This technique would be used only to control noxious weeds.

Herbicides. Herbicides to kill target plants would be applied from the ground, using hand-pumped backpack sprayers. No chemicals would be applied using rubber-tired tractors, trucks, truck-mounted sprayers, or tracked vehicles. No aerial spraying would be done. Herbicides proposed for this project are approved under the Mediated Agreement. Herbicides could be applied in the following ways, depending on the zone: -

- Cut-stump application: Herbicide is applied to the surface of cut stumps of hardwood trees and shrubs to prevent re-sprouting. 
- Basal application: Herbicide is applied to the surface of the target tree's main stem, from ground level to a height of $30-45$ centimeters (12 - 18 inches).

- Spot foliar: Herbicide is applied directly to the individual target plant's foliage.

Mechanical methods, which use crawler tractors or low-ground-pressure tractors with blades or mowing attachments to cut, till, or mow undesirable plants, would not be used (see section 2.3).

\subsubsection{Treatment Zones}

The Bonneville-Hood River transmission line right-of-way was divided into five treatment zones. The zones are distinguished by site characteristics such as slope and the presence or absence of significant resources such as streams; special visual quality, or sensitive habitat. The site characteristics determine the type of vegetation management techniques and herbicides allowed in that zone: treatments are limited by each zone's most environmentally constraining characteristic. Chapter 3 describes the process used to determine the zones and allowable techniques in more detail.

Table 1 defines the proposed zones and their treatments. Figure 2 shows the location of the zones along the right-of-way.

\subsection{Status Quo Alternative}

BPA would continue the current practice of controlling undesirable vegetation on the Bonneville-Hood River right-of-way, using primarily manual and biological methods as described for the Proposed Action. No chemical methods (herbicides) would be used. This alternative corresponds most closely to the USFS "Maintenance" strategy, in which treatment activities are administered in small, frequent doses in order to maintain current conditions.

Methods used would continue to depend on species' growth characteristics and proximity to sensitive resources such as streams. These areas would be defined on a case-by-case basis; zones of allowable vegetation management techniques would not be defined. As is current practice,.methods frequently would be used in combination with one another.

\subsection{Options Eliminated from Detailed Evaluation}

\subsubsection{Mechanical Techniques}

Because of the poor access and steep terrain of most of the right-of-way, mechanical mowing methods were eliminated from consideration. Such equipment either could not reach the right-of-way or, if it did, the resulting ground disturbance could cause unacceptable problems with erosion in the steep terrain.

\subsubsection{Prescribed Burning}

The USFS recognizes prescribed burning (in addition to manual, mechanical, biological and chemical methods) as a reasonable vegetation management technique in many 
circumstances. Fire near electrical lines, however, poses a major threat to system operations. Smoke coats the insulators, thus allowing the power to flash past the insulators and go to ground, interrupting service. For this reason, prescribed burning is not a reasonable vegetation management technique for transmission line rights-of-way.

\section{Table 1 Treatment Zones}

\begin{tabular}{|c|c|}
\hline Zones & Treatment Method \\
\hline STC & $\begin{array}{l}\text { Any areas in the corridor with greater than } 38 \text { meters }(\mathrm{m})(125 \text { feet }[\mathrm{ft}]) \text { vertical distance } \\
\text { between the ground surface and transmission lines. } \\
\text { Methods: Individual trees that could grow or fall into the transmission conductor danger } \\
\text { zone would be removed by manual methods. Any vegetation growing within } 5 \mathrm{~m}(16 \mathrm{ft}) \text { of } \\
\text { the conductor would be considered within the danger zone. Noxious weeds would be } \\
\text { removed using biological or spot-foliar herbicide treatments. } \\
\text { Herbicides: Glyphosate, picloram, triclopyr, and dicamba may be prescribed to kill noxious } \\
\text { weeds only. }\end{array}$ \\
\hline $\mathbf{R}$ & $\begin{array}{l}\text { Any areas in the corridor within } 91 \mathrm{~m}(300 \mathrm{ft}) \text { of surface waters. } \\
\text { Methods: All manual and biological treatments; cut-stump herbicide treatments only. } \\
\text { Herbicides: Rodeo }{ }^{\mathrm{tm}} \text { formulation of glyphosate only, with a 3-m (10-ft) buffer around } \\
\text { surface waters. }\end{array}$ \\
\hline $\mathbf{V}$ & $\begin{array}{l}\text { Lands that have either a significant visual resource or habitat suitable for Forest Sensitive } \\
\text { species.' Steep slopes }(>25 \%) \text { may also be present. } \\
\text { Methods: All manual, biological, and allowable herbicide treatments. } \\
\text { Herbicides: Glyphosate, picloram, triclopyr, and dicamba may be prescribed for cut-stump, } \\
\text { basal-application, or spot-foliar treatments. Herbicide use would be restricted in sensitive } \\
\text { species habitat or in potential habitat areas. }\end{array}$ \\
\hline $\mathbf{S S}$ & $\begin{array}{l}\text { Lands with a steep slope }(>25 \%) \text {. } \\
\text { Methods: All manual, biological, and allowable herbicide treatments. } \\
\text { Herbicides: Glyphosate, picloram, triclopyr, and dicamba may be prescribed for cut-stump, } \\
\text { basal-application, or spot-foliar treatments. }\end{array}$ \\
\hline $\mathbf{Z}$ & $\begin{array}{l}\text { Land classified by the USFS as Late-Successional Reserve (LSR) })^{2} \text { with no other } \\
\text { environmental constraints. } \\
\text { Methods: All manual, biological and allowable herbicide treatments. } \\
\text { Herbicides: Glyphosate, picloram, triclopyr, and dicamba may be prescribed for cut-stump, } \\
\text { basal-application, or spot-foliar treatments. }\end{array}$ \\
\hline
\end{tabular}

1 Forest Sensitive species: Those.plant and animal species identified by a Regional Forester for which population viability is a concern, as evidenced by: a significant current or predicted downward trend in population numbers or density; or a significant current or predicted downward trend in habitat capability that would reduce a species' existing distribution (Forest Service Manual 2670.5(19)). In: Spotted Owl Management EIS, USFS, Jan. 1992.

2 Late Successional Reserves (LSR).are identified to protect and enhance conditions of mature and oldgrowth forest ecosystems which serve as habitat for species adapted to those conditions. 


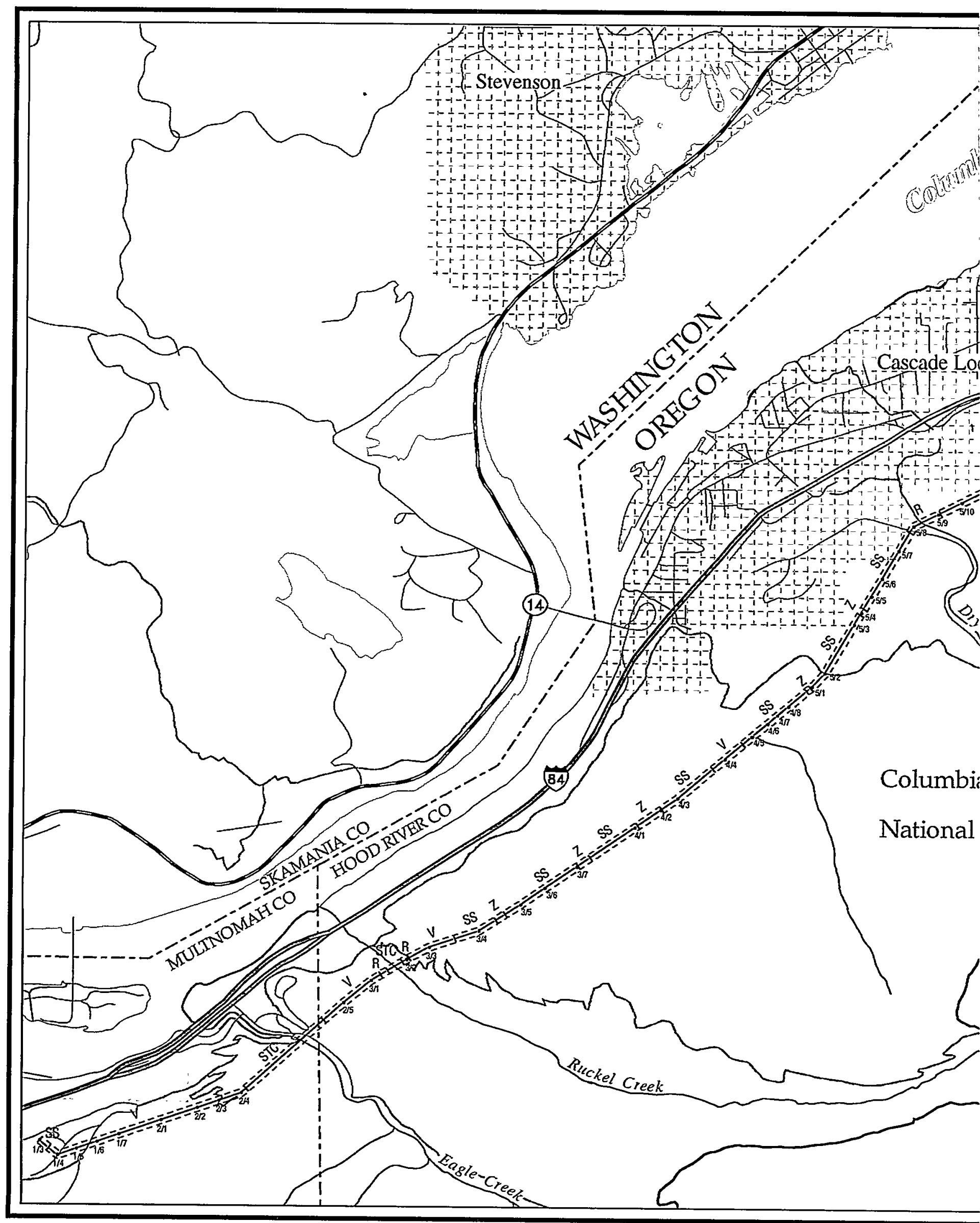




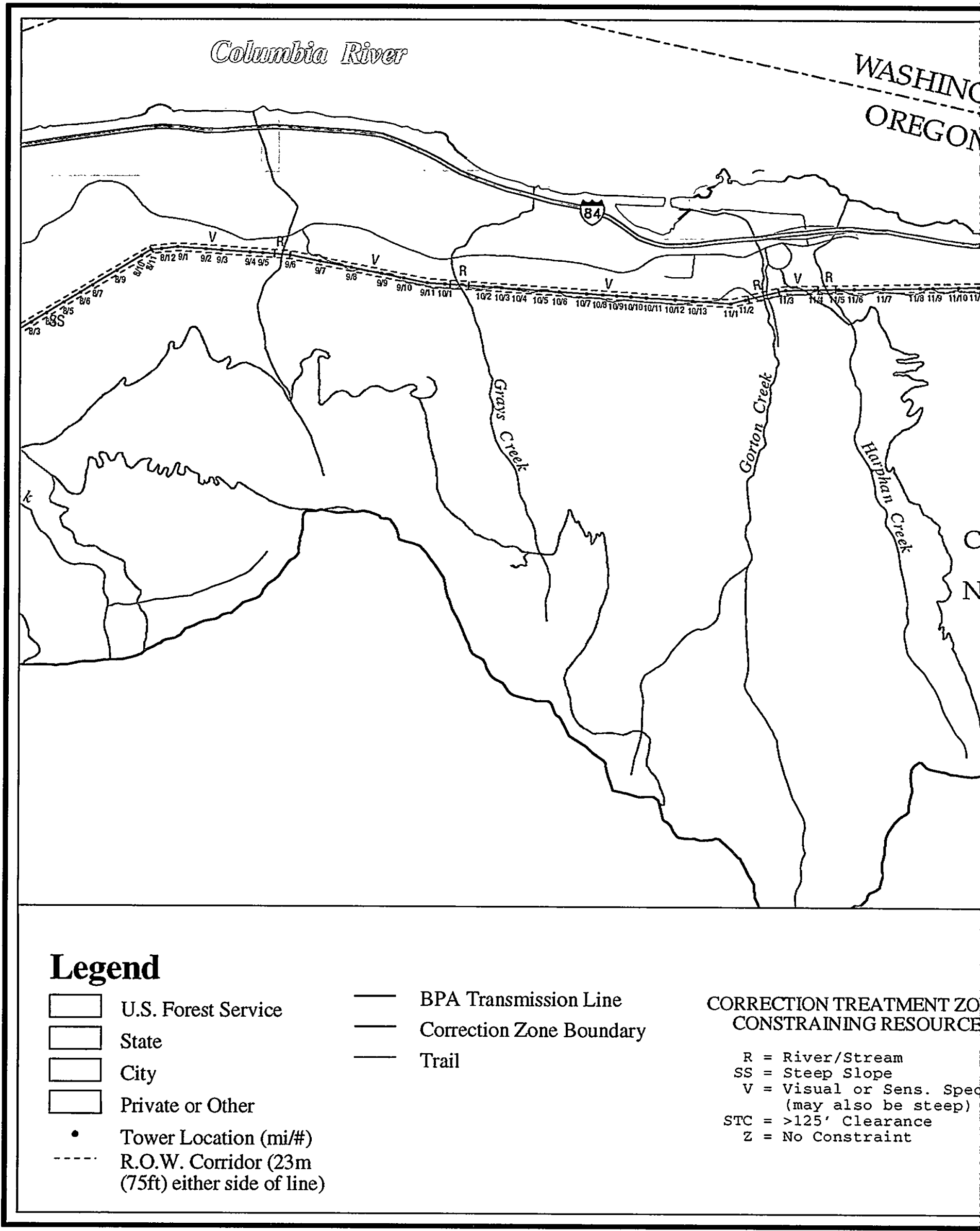




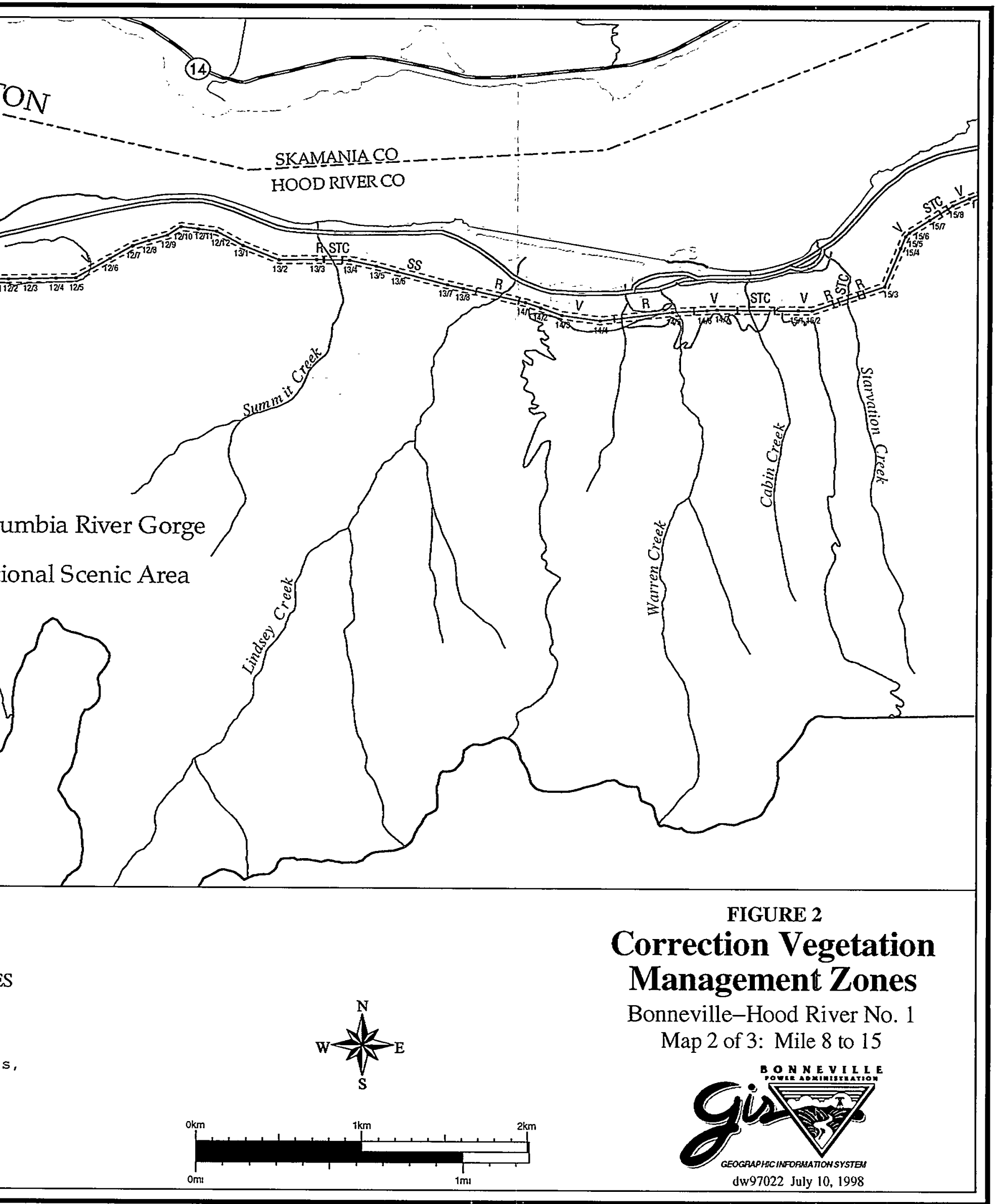




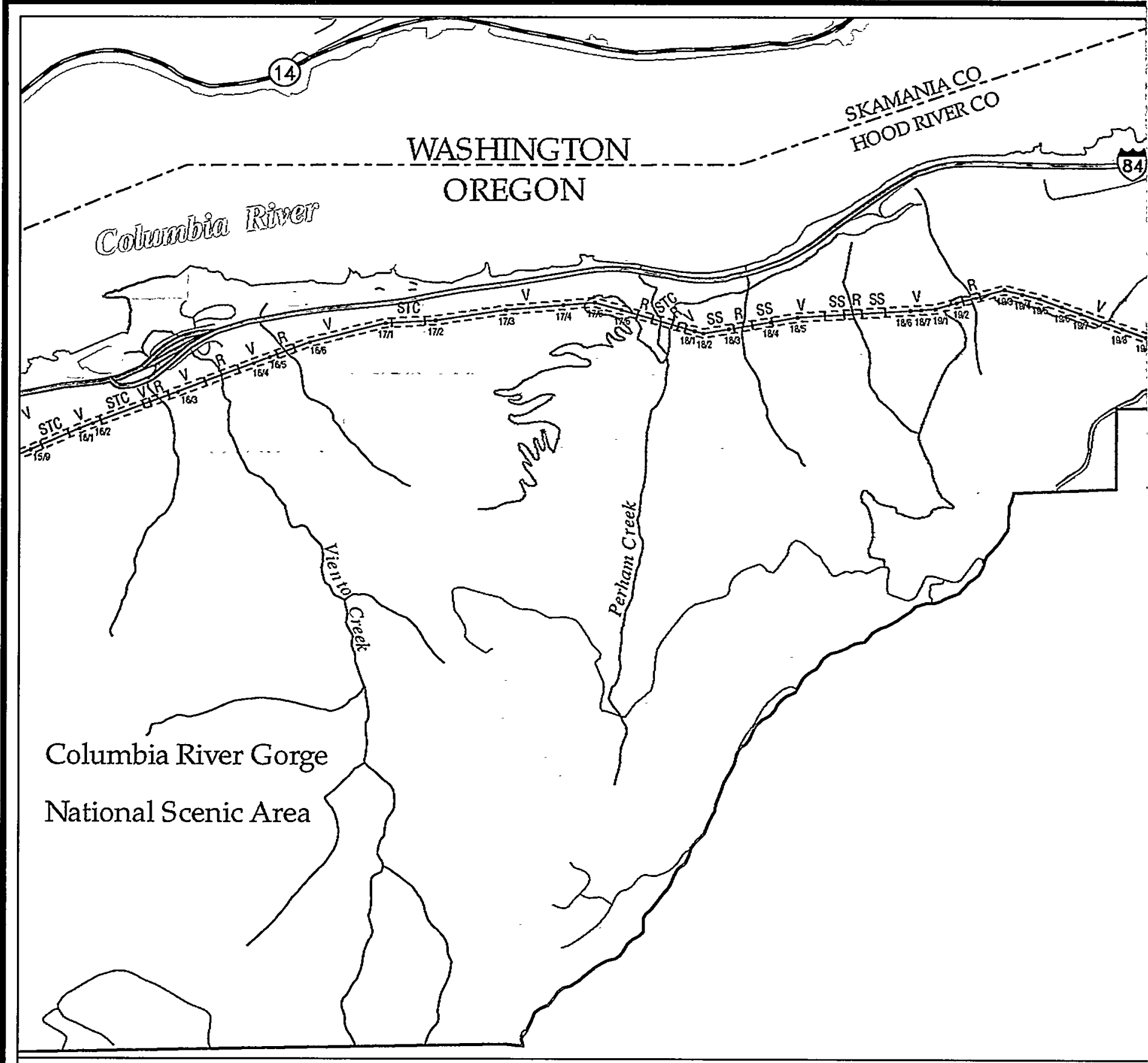

\section{Legend}

\begin{tabular}{|lll}
\hline & U.S. Forest Service & BPA Transmission Line \\
\hline & State & Correction Zone Boundary \\
\hline & County & Trail \\
\hline & Private or Other & \\
$-\quad \begin{array}{l}\text { Tower Location (mi/\#) } \\
\text { R.O.W. Corridor (23m } \\
\text { (75ft) either side of line) }\end{array}$ &
\end{tabular}
CORRECTION TREATMENT ZO CONSTRAINING RESOURCE

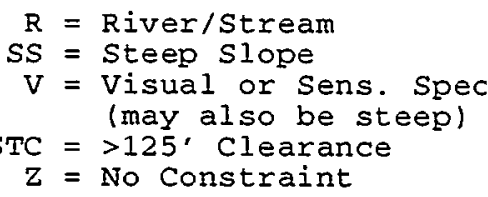




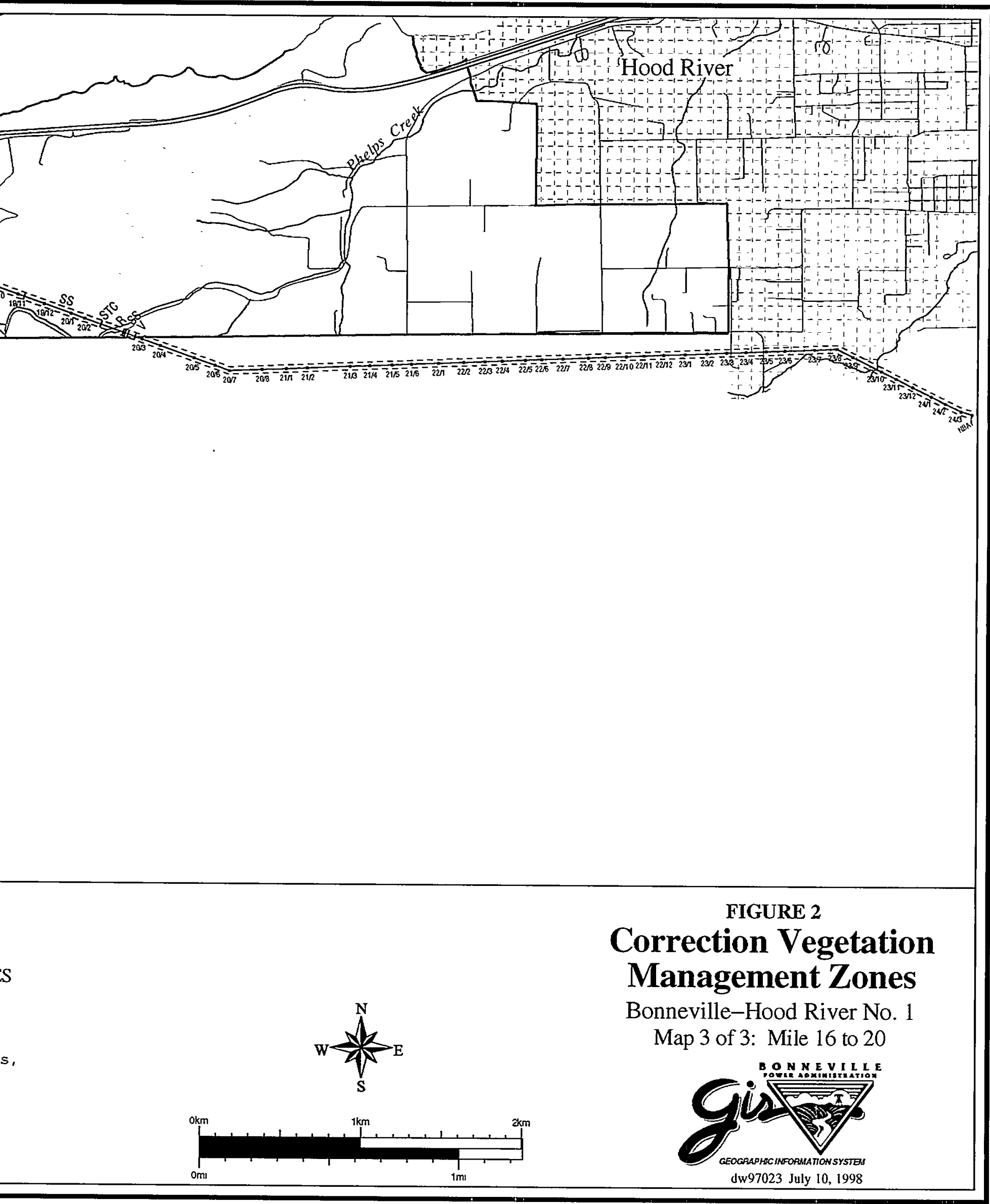




\subsection{Performance of Alternatives}

Table 2 summarizes how the alternatives meet the purposes for the project as described in section 1.2 .

Table 2 Predicted Performance Summary

\begin{tabular}{|l|l|l|}
\hline Decision Factor & Proposed Action & Status Quo \\
\hline $\begin{array}{l}\text { Complies with national } \\
\text { and regional policies and } \\
\text { mandates }\end{array}$ & In compliance. & In compliance. \\
\hline $\begin{array}{l}\text { Protects the natural and } \\
\text { human environment }\end{array}$ & $\begin{array}{l}\text { Protects sensitive resources } \\
\text { by defining resource zones, } \\
\text { within which vegetation } \\
\text { control techniques are } \\
\text { tailored to the sensitivity of } \\
\text { resources within each zone. } \\
\text { Allows treatment method } \\
\text { considered to be low risk to } \\
\text { safety of workers, according } \\
\text { to OSHA. }\end{array}$ & $\begin{array}{l}\text { May protect some sensitive } \\
\text { plant resources by not using } \\
\text { herbicides, but may harm } \\
\text { others due to annual } \\
\text { trampling and disturbance } \\
\text { on steep slopes. Worker } \\
\text { safety continues to be high } \\
\text { risk with higher frequency } \\
\text { of chainsaw use. }\end{array}$ \\
\hline $\begin{array}{l}\text { Maintains reliability of } \\
\text { the FCRTS }\end{array}$ & $\begin{array}{l}\text { Reduces the potential of } \\
\text { tree-caused outages, and the } \\
\text { need for annual re- } \\
\text { treatments. Increases } \\
\text { opportunity to establish } \\
\text { low-growing vegetation } \\
\text { communities and potential } \\
\text { to achieve long-term goal of } \\
\text { prevention. }\end{array}$ & $\begin{array}{l}\text { Reduces the potential of } \\
\text { tree-caused outages. } \\
\text { Requires frequent re- } \\
\text { cutting. Little opportunity to } \\
\text { achieve long-term goal of } \\
\text { prevention. }\end{array}$ \\
\hline $\begin{array}{l}\text { Provides administrative } \\
\text { efficiency and cost } \\
\text { effectiveness }\end{array}$ & $\begin{array}{l}\text { Allows for lower long-term } \\
\text { costs because of lower } \\
\text { treatment cost and fewer } \\
\text { repeat treatments. Broader } \\
\text { range of techniques } \\
\text { maximizes efficiency of } \\
\text { treatments. Zone system } \\
\text { ensures consistent treatment } \\
\text { in similar areas. }\end{array}$ & $\begin{array}{l}\text { Maintains higher long-term } \\
\text { costs because of annually } \\
\text { increasing treatment costs. } \\
\text { The limited number of } \\
\text { techniques means more } \\
\text { frequent maintenance is } \\
\text { required; consistent } \\
\text { treatments in similar areas } \\
\text { are not guaranteed. }\end{array}$ \\
\hline
\end{tabular}




\section{CHAPTER 3 AFFECTED ENVIRONMENT AND ENVIRONMENTAL CONSEQUENCES}

The proposal would control vegetation along $30 \mathrm{~km}(19 \mathrm{mi})$ of transmission line right-ofway in the Columbia River Gorge National Scenic Area between Bonneville Dam (west of Cascade Locks) and Hood River, Oregon. Using Geographic Information System (GIS) data from the USFS, supplemented with field work performed by USFS and BPA specialists, BPA mapped the resources likely to be affected by various vegetation management activities. The right-of-way was then divided into proposed treatment . zones. These zones, developed by BPA, USFS, and a consultant (David Evans and Associates, 1996), define the vegetation management activities allowed in that zone based on the presence of the most sensitive resource. Vegetation control techniques are designated that would not adversely affect the sensitive resources in that zone. Table 1 (Chapter 2) defines the zones; Figure 2 (Chapter 2) shows where the zones are along the transmission line; Table 3 (below) indicates the amount of land in each zone.

Table 3 Amount of Right-of-way in Treatment Zones
\begin{tabular}{|c|c|c|}
\hline Zone & Length: km (mi) & Area: ha (ac) \\
\hline STC & $2.1(1.3)$ & $9.3(23.2)$ \\
\hline R & $2.6(1.6)$ & $11.3(28.3)$ \\
\hline V & $15.2(9.5)$ & $69.0(172.6)$ \\
\hline SS & $9.9(6.2)$ & $45.1(112.8)$ \\
\hline Z & $0.5(0.3)$ & $1.8(4.5)$ \\
\hline
\end{tabular}

The remainder of the chapter describes the existing environment and the effects of vegetation management alternatives on natural and human resources in the project study area. Table 4 summarizes that information.

\subsection{Study Area}

About $65 \%$ of the project area is within the Mt. Hood National Forest and the Columbia Gorge NSA, although about $12 \mathrm{~km}$ ( $7.5 \mathrm{mi})$ crossès state, city and private ownerships. The right-of-way passes through three state parks: Wygant State Park, Vinzenz Lausmann Memorial State Park and Seneca Fouts Memorial State Park. In this project area, the eastern boundary of the NSA is at Vinzenz Lausmann State Park, several miles west of Hood River, Oregon. 
Table 4 Affected Environment and Environmental Consequences Summary

\begin{tabular}{|c|c|c|c|}
\hline $\begin{array}{l}\text { Environ- } \\
\text { mental } \\
\text { Resource }\end{array}$ & Existing Conditions & Proposed Action & Status Quo \\
\hline Vegetation & $\begin{array}{l}\text { Most of ROW in dense thickets } \\
\text { of shrubs and seedlings of } \\
\text { alder, maple, and conifers; in } 2 \\
\mathrm{~km} \text {, conductors are high } \\
\text { enough to leave mature hem- } \\
\text { lock/Douglas fir stands. Poten- } \\
\text { tial habitat for } 28 \text { sensitive } \\
\text { plant species but only one } \\
\text { found (long-bearded } \\
\text { hawkweed). }\end{array}$ & $\begin{array}{l}\text { Herbicides allow change from tall- } \\
\text { growing species to low-growing } \\
\text { shrubs. Noxious weeds eliminated. } \\
\text { Low risk of impact to sensitive species } \\
\text { from trampling, felling trees, and } \\
\text { herbicides. P zone protects long- } \\
\text { bearded hawkweed and known } \\
\text { sensitive habitat. }\end{array}$ & $\begin{array}{l}\text { Focus on manual cutting would } \\
\text { leave vegetation unchanged. } \\
\text { Noxious weeds would continue } \\
\text { to multiply. Sensitive species } \\
\text { could be affected by trampling } \\
\text { or tree-felling. }\end{array}$ \\
\hline Wildlife & $\begin{array}{l}\text { Large and small mammals; } \\
\text { birds, including raptors; fish } \\
\text { and other species inhabit area. } \\
\text { Sensitive species habitat } \\
\text { includes spotted owl dispersal, } \\
\text { reproductive and foraging } \\
\text { habitat. }\end{array}$ & $\begin{array}{l}\text { Wildlife temporarily disturbed a few } \\
\text { days every } 2-3 \text { years when workers } \\
\text { present. Spotted owl habitat not } \\
\text { affected because fewer than } 10 \text { trees } \\
\text { per acre removed. Herbicides } \\
\text { proposed do not bioaccumulate, but } \\
\text { some may be hazardous or slightly } \\
\text { toxic to some species. R zone protects } \\
\text { aquatic species from herbicides. }\end{array}$ & $\begin{array}{l}\text { Wildlife could be disturbed } \\
\text { more often than under proposal } \\
\text { because workers would return } \\
\text { at least annually. }\end{array}$ \\
\hline Soils & $\begin{array}{l}\text { Soils are primarily volcanic, } \\
\text { often cobbly, on steep slopes. } \\
\text { Rock outcrops and cliffs are } \\
\text { common. Erosion and mass } \\
\text { movement is evident in much } \\
\text { of the area. }\end{array}$ & $\begin{array}{l}\text { Slight run-off and localized erosion } \\
\text { would recur until low-growing } \\
\text { vegetation is established. Herbicides } \\
\text { unlikely to build up in soils due to } \\
\text { herbicide characteristics and neutral to } \\
\text { moderately acidic soils. }\end{array}$ & $\begin{array}{l}\text { Erosion and run-off potential } \\
\text { slightly higher than proposal } \\
\text { due to workers annually } \\
\text { traversing steep slopes. }\end{array}$ \\
\hline $\begin{array}{l}\text { Water } \\
\text { Resources }\end{array}$ & $\begin{array}{l}\text { ROW crosses } 15 \text { perennial and } \\
8 \text { intermittent streams with } \\
\text { steep gradients, which flow } \\
\text { into the Columbia River a half } \\
\text { mile away. }\end{array}$ & $\begin{array}{l}\text { Low impact on water quality because } \\
\text { new stream surface exposed is } \\
\text { minimal; } R \text { zone protects water from } \\
\text { herbicide effects; and erosion and } \\
\text { sedimentation are low. }\end{array}$ & $\begin{array}{l}\text { Slightly greater sedimentation } \\
\text { impacts than proposal due to } \\
\text { annual worker disturbance. }\end{array}$ \\
\hline $\begin{array}{l}\text { Visual and } \\
\text { Recreation } \\
\text { Resources }\end{array}$ & $\begin{array}{l}\text { Project is in CRGNSA, estab- } \\
\text { lished to preserve scenic qual- } \\
\text { ity. ROW visible from many } \\
\text { scenic and recreational sites. }\end{array}$ & $\begin{array}{l}\text { No noticeable change to visual quality } \\
\text { because no broadcast herbicide } \\
\text { spraying allowed. All visually } \\
\text { sensitive sites in. } V \text { zone. }\end{array}$ & $\begin{array}{l}\text { Visual quality would remain } \\
\text { the same. }\end{array}$ \\
\hline $\begin{array}{l}\text { Human } \\
\text { Health and } \\
\text { Safety }\end{array}$ & $\begin{array}{l}\text { This ROW has no history of } \\
\text { maintenance worker accidents, } \\
\text { although others do. ROW is } \\
\text { accessible to hikers, mountain } \\
\text { and dirt bikers. }\end{array}$ & $\begin{array}{l}\text { Moderate risk to workers of } \\
\text { reproductive or general health effects } \\
\text { from backpack sprayers using } \\
\text { dicamba, glyphosate, or triclopyr. } \\
\text { Reduced risk of accidents to workers } \\
\text { using manual methods due to fewer } \\
\text { visits, less dense vegetation. }\end{array}$ & $\begin{array}{l}\text { Current risk of worker acci- } \\
\text { dents from manual methods } \\
\text { continues or increases as vege- } \\
\text { tation from repeated manual } \\
\text { cuttings becomes more dense. }\end{array}$ \\
\hline Air Quality & $\begin{array}{l}\text { CRGNSA is Class II airshed, } \\
\text { allowing for moderate } \\
\text { degradation of air quality. }\end{array}$ & $\begin{array}{l}\text { Short-term, minimal air quality } \\
\text { reductions from vehicle/ machinery } \\
\text { exhaust, herbicides. }\end{array}$ & $\begin{array}{l}\text { Air quality reductions from } \\
\text { exhaust slightly higher than } \\
\text { proposal due to more visits. }\end{array}$ \\
\hline
\end{tabular}


Project area topography varies from moderate to very steep slopes, including some areas with almost vertical cliffs. Area elevations range from approximately $15 \mathrm{~m}(50 \mathrm{ft})$ at the western boundary to approximately $244 \mathrm{~m}(800 \mathrm{ft})$ in several areas. Steep slopes are common on one or both sides of creeks, which tend to flow in narrow canyons.

\subsection{Vegetation}

The current vegetation management program has converted approximately $27 \mathrm{~km}$ (17 mi) of mature conifer forest to shrubs and tree seedlings characteristic of disturbed areas. In a few places, the right-of-way crosses $1.2 \mathrm{~km}(0.8 \mathrm{mi})$ of rocky outcrops and extended talus slopes such as those on the sides of Shellrock Mountain. Approximately $2 \mathrm{~km}(1.2 \mathrm{mi})$ of undisturbed mature conifer forest, primarily western hemlock/Douglas fir types, remain where the transmission conductors are high enough above the tree canopy that vegetation management activities are unnecessary, except for occasional single tree removal.

\section{- 3.2.1 Proposed Action}

Because most of the area, if left alone, would produce tall-growing conifers and shrubs, any vegetation management program to keep tall-growing vegetation from interfering with transmission lines would adversely affect those species. If successful, the IVM program would, to a certain degree, also change the character of the vegetation in those parts of the right-of-way that now contain tall-growing shrubs and tree seedlings. Currently many of those areas, which have been subject to manual cutting for over a decade, contain dense thickets of red alder, bigleaf maple, other hardwoods, and young - conifers. In those areas, in all zones except STC, the potential use of herbicides may prevent the re-growth of the tall-growing vegetation types and promote the establishment of low-growing native shrubs such as ocean spray,(Holodiscus discolor), thimbleberry (Rubus parviflorus), snowberry (Symphoricarpos albus), and vine maple (Acer circinatum). Current invasions of noxious weeds are more likely to be controlled than under the existing program because herbicides would destroy the plants, whereas hand pulling and cutting allows them to re-sprout.

Areas in STC zones are nearly all western hemlock/Douglas fir types, with a few hundred feet at the eastern end of the project right-of-way in Douglas fir/grand fir or bigleaf maple. Removal of tall-growing vegetation in these zones is rarely required, so the vegetation would remain unchanged.

Because broadcast foliar herbicide treatments are not proposed in any zones, non-target species are unlikely to be adversely affected.

\subsubsection{Status Quo}

Continuing the current vegetation management program of primarily manual cutting would leave vegetation types unchanged. Although efforts to retard growth and halt the spread of several dense stands of Scot's broom using biological agents would continue, noxious weeds along roadways would continue to multiply. 


\subsubsection{Endangered, Threatened, and Sensitive Plants}

In summer of 1997, a plant biologist surveyed the right-of-way for Region 6 Sensitive Plants listed for the Mt. Hood National Forest, for endemic species (those that occur only within the Columbia River Gorge and vicinity), for state-listed species, and for species on Oregon Natural Heritage Program (ONHP) Lists 1 through 4 (as described in the Management Plan for the Columbia River Gorge National Scenic Area, 1992). While potential habitat for 28 sensitive species occurs along the right-of-way, only one sensitive species, long-bearded hawkweed (Hieracium longiberbe), actually was found during the survey. This species is an endemic species; it is not federally or state-listed. ONHP places long-bearded hawkweed on List 4 , which means it merits long-term concern because it may be rare or declining, but it is still apparently secure or too common to be threatened or endangered. No federally listed endangered or threatened plant species have been found in the project area.

\subsubsection{Proposed Action and Status Quo}

Table 5 summarizes the effects of each vegetation management alternative on sensitive species. The potential for direct, indirect and cumulative impacts was considered.

Under both alternatives, direct impacts could include trampling by maintenance crew members. Under the Proposed Action, in zones where spot herbicide spraying is allowed, the destruction of sensitive species could be a direct impact. Because ground disturbing activities are not proposed for either alternative, direct impacts would not include disturbance to the below-ground portions of plants.

The use of biological agents, such as seed weevils, is not expected to directly or indirectly harm sensitive species because the agents target specific noxious weed species. A few botanists have expressed concerns that some biological agents are not as specific in their targets as expected. For example, the biological agent released to kill tansy ragwort (Senecio jacobaea) was known to attack native members of the genus Senecio in the 1960s and 1970s. Concerns about attacks on native Senecio dictated advancements in the testing of the biological agents; those used today in Oregon undergo extensive testing by the Oregon Department of Agriculture (ODA) to ensure they target only specific plants. The proposed project may use ODÄ-approved biological agents for knapweed species (Centaurea sp.) and Scot's broom (Cytisus scoparius); however, there are no members of these two genera on the sensitive species list, minimizing the possibility that native species would be harmed by the release of these biological agents.

The impact of project activities on the habitats of sensitive species was also considered. Removing trees and brush could change the composition of plant communities in shaded areas by opening the tree canopy. Biological methods which encourage a change in the plant community could also alter the habitat such that a sensitive species could no longer survive. An additional potential indirect impact is the effect tree and brush removal would have on the viability of individuals that normally grow in shady habitats. However, because the areas that require removal of woody species have been subject to tree cutting and disturbance in the past, the herbaceous plants in these areas generally are not native, shade-loving species that would suffer from an increase in light intensity. 
Table 5 Summary of Effects on Sensitive Plant Species

\begin{tabular}{|c|c|c|c|}
\hline Species & $\begin{array}{c}\text { Habitat Not } \\
\text { Present }\end{array}$ & Status Quo & $\begin{array}{l}\text { Proposed } \\
\text { Action } \\
\end{array}$ \\
\hline Agrostis howellii & & NI & NI \\
\hline Arabis furcata & & NI & NI \\
\hline Bolandra oregana & & NI & NI \\
\hline Calamagrostis howellii & & MIIH & MIIH \\
\hline Carex macrochaeta & & MIIH & MIIH \\
\hline Castilleja rupicola & - & NI & NI \\
\hline Cimicufuga elata & & MIIH & MIIH \\
\hline Corydalis aquae-gelidae & & MIIH & MIIH \\
\hline Cypripedium fasciculatum & $\mathbf{X}$ & $-\cdots$ & $\ldots$ \\
\hline Cypripedium montanum & $\mathbf{X}$ & $\cdots$ & $\cdots$ \\
\hline Delphinium leucophaeum & & NI & NI \\
\hline Delphinium nutallii & & MIIH. & MIIH \\
\hline Dodecatheon poeticum & & MIIH & MIIH \\
\hline Douglasia laevigata var. laevigata & & NI & NI \\
\hline Erigeron howellii & & NI & NI \\
\hline Erigeron oreganus & & NI & NI \\
\hline Hackelia difusa var. diffusa & & MIIH & MIIH \\
\hline Hieracium longiberbe & $\dot{-}$ & MIIH & MIIH \\
\hline Lewisia columbiana var. columbiana & & NI & NI \\
\hline Montia diffusa. & & MIIH & MIIH \\
\hline Montia howellii & $\mathbf{X}$ & $\ldots$ & $\ldots$ \\
\hline Ophioglossum pusillum & $\mathbf{X}$ & $\cdots$ & $\cdots$ \\
\hline Penstemon barrettiae & $\cdot$ & $\mathbf{N I}$ & NI \\
\hline Poa gracillima var. multnomae & & MIIH & MIIH \\
\hline Poa laxiflora & & NI & NI \\
\hline Suksdorfia violacea & & MIIH & MIIH \\
\hline Sullivantia oregana & & NI & NI \\
\hline Syntheris stellata & & MIIH & MIIH \\
\hline
\end{tabular}

$\mathrm{NI}=\quad$ No Impact

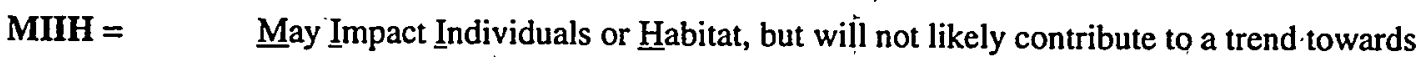
federal listing or to a population's or species' loss of viability

WIFV $=\quad$ Will Impact individuals or habitat such that the action may contribute to a trend towards Federal listing or cause a population's or species' loss of Viability

$\mathbf{B I}=\quad$ Beneficial Impact 
In general, as shown in Table 5, the level of effect on sensitive plants would be the same for both alternatives, although the source of the impact may be different. Those species that show no impact (NI) are in terrain where vegetation removal activities are unlikely, such as on cliffs, rock outcrops, talus slopes, under basalt overhangs or in an STC or P zone. (The $\mathrm{P}$ zone was created as a mitigation measure--see section 3.2.3.2.) For those species that show a "may impact" (MIIH) determination, the impact would be from trampling by maintenance workers, from trees being felled onto plants and not removed, and from herbicide use. The likelihood of effect is in most cases low, not likely to contribute to loss of viability of the population, and can be mitigated, as discussed in section 3.2.3.2.

\subsubsection{Mitigation}

Mitigation measures for this project include avoiding potential habitat areas when feasible, using herbicides according to established protocol, conducting maintenance activities in sensitive species habitat at a time of year when they will have the least impact, keeping debris from felled trees out of potential habitat areas, and adopting a prevention strategy which will decrease the need for vegetation management activities. These mitigation measures are discussed below.

\section{PROPOSED ACTION}

Creation of the P Zone to Protect Sensitive Species. To provide additional protection to sensitive species, a "P" zone was created for areas where proposed, endangered, threatened or sensitive species are suspected or documented. Three $\mathrm{P}$ zones were designated, based on previously published reports of sightings and one actual site identified during the 1997 survey. If sensitive plant habitat was in a zone with adequate protection (e.g., $\mathrm{R}$ zone), a new $\mathrm{P}$ zone was not identified. Locations of sensitive plant species and potential habitat have been mapped for use by BPA maintenance workers but are not published in this document to avoid the potential for removal by collectors of rare plants.

Manual clearing is allowed in $\mathrm{P}$ zones, but other restrictions such as time and method of clearing may be imposed in areas where sensitive species are documented, based on the ecology and habitat of individual species. The $\mathrm{P}$ zone imposes restrictions on herbicide use. Cut-stump and basal application treatments will be allowed, but spot spraying will not, unless an invasion by noxious weeds mandates this technique. For example, Scot's broom might resist control by manual methods. Spot spraying will be prohibited between April 1 and July 15 to avoid harming sensitive plants. In known habitat areas, herbicide use could be further restricted based on the impacts to sensitive species.

The area where long-bearded hawkweed was found has been designated a $\mathrm{P}$ zone. Maintenance workers will be given aerial photomaps showing long-bearded hawkweed habitat. The mapped area includes a buffer of 25 feet around individual plants. Because diffuse knapweed grows along the roadways adjacent to the long-bearded hawkweed habitat, only hand pulling will be allowed in the disturbed area next to the road. If Scot's broom invades the habitat, spot spraying can be used except between April 1 and July 15, when spraying could harm long-bearded hawkweed. 
Herbicide Use Restrictions. Herbicide use would be allowed in some vegetation management zones under the Proposed Action. Herbicide handling and use must be done according to label instructions, by licensed, certified applicators, in accordance with precautions outlined in the Herbicide Information Profiles developed by the USFS PNW Region (Appendix B). With spot foliar treatments, applicators would apply herbicides only to target vegetation, with no dripping onto adjacent vegetation. After spraying, areas may be seeded or planted to prevent subsequent re-establishment of noxious weeds and other non-native species, if needed.

Prevention Strategies. For the Proposed Action, a "prevention strategy" would be adopted, which includes encouraging low-growing plant communities that prevent or discourage tree seedling establishment. Attractive native shrub species present along the right-of-way include oceanspray, vine maple, snowberry, and thimbleberry. These communities provide habitat and food for wildlife', while resiśting invasion by non-native species and weeds such as knapweed and Scot's broom. In addition, shrubs would discourage dirt bikers, who were encountered on maintenance roads during the survey, from creating additional trails in open areas. Dirt bikes could cause scars that would revegetate slowly and be prone to erosion in this rugged terrain.

\section{STATUS QUO AND PROPOSED ACTION}

Routine Maintenance Including Removal of Woody Vegetation. Minimal woody species removal would be done adjacent to cliffs and rocky areas, to prevent an increase in light intensity that might harm shade-dwelling species. Trees that are felled into potential habitat areas, such as rocky slopes and seeps, would be removed so that they do not shade or cover sensitive species or alter habitat conditions. If possible, trees would be felled into disturbed habitat, where they, will not affect sensitive species.

Because long-bearded hawkweed thrives both in open and shaded areas, shrub and tree removal will not have any negative, indirect impacts to this species due to a change in light intensity or exposure. To avoid trampling long-bearded hawkweed, woody vegetation would not be removed during the early growth and reproductive stages; between April 1 and July 15. If trees or shrubs are felled within or into the habitat of long-bearded hawkweed, they would be removed.

\subsection{Wildlife}

The wildlife inhabiting and using the right-of-way include a diversity of birds, from song birds to raptors; large mammals including black tail deer (Odocoileus virginianus), elk (Cervus canadensis), and bear (Ursus americanus); and a host of other small mammals; insects, amphibians, reptiles, and micro-organisms.

Although the right-of-way has dissected the conifer forest, the resulting edge effects and habitat diversity have increased the habitat for some species. Deer and elk forage in these areas; certain song birds nest and feed there; and small mammals occupy the shrub habitat. On the other hand, the right-of-way has somewhat reduced the large tracts of conifer forest required for some species such as the spotted owl and flying squirrel. 
Table 6 shows endangered and threatened species listed under the Endangered Species. Act (ESA), those proposed for federal listing, and sensitive species as defined by

Region 6 of the USFS. The entire project area is within a Habitat Conservation Area and a Critical Habitat Unit for the spotted owl.

Although the gray wolf (Canis lupus) is listed under ESA as endangered, and historical records of its presence in the Mt. Hood National Forest exist, a recovery plan for this species has not been initiated for Oregon. In addition, Region 6 of the USFS recommends that impacts to this species be assessed only in the North Cascades and Selkirk Mountains of Washington (Larson, 1998).

Table 6 Sensitive Wildlife Species in Project Area

\begin{tabular}{|l|l|}
\hline Species & Status \\
\hline Peregrine Falcon & Endangered (ESA) \\
\hline Snake River Sockeye Salmon & Endangered (ESA) \\
\hline Northern Bald Eagle & Threatened (ESA) \\
\hline Northern Spotted Owl & Threatened (ESA) \\
\hline Lower Columbia River Steelhead & Threatened (ESA) \\
\hline Snake River Chinook Salmon & Threatened (ESA) \\
\hline Bull Trout & Proposed Threatened (ESA) \\
\hline Cope's Giant Salamander & Sensitive (Region 6) \\
\hline Larch Mountain Salamander & Sensitive (Region 6) \\
\hline Painted Turtle & Sensitive (Region 6) \\
\hline Northwestern Pond Turtle & Sensitive (Region 6) \\
\hline California Mountain Kingsnake & Sensitive (Region 6) \\
\hline Columbia Gorge Neothremman Caddisfly & Sensitive (Region 6) \\
\hline
\end{tabular}

Wildlife could be affected by vegetation management activities in several ways. Workers can disturb wildlife, especially if work is done near nests or dens during the breeding season. Vegetation removal can destroy habitat for some species. In addition, although the data are limited, one or more of the herbicides may be hazardous or slightly toxic to some species of wildlife or invertebrates.

\subsubsection{Proposed Action}

In all proposed vegetation management zones except STC zones, wildlife would be temporarily disturbed by workers entering the area to cut vegetation or to apply

. herbicides. However, these events would occur for only a few days every year for the first two or three years, then for a few days every three years, once low-growing vegetation is established. 
In zones V, Z, and SS, BPA could use any one of four herbicides--triclopyr, picloram, glyphosate, and dicamba--in cut-stump, spot-foliar, and basal applications. Their potential to affect terrestrial wildlife is discussed in the Herbicide Information Profiles in Appendix B and summarized below. Herbicides used in spot foliar and stem treatments are not expected to affect wildlife because there is little or no potential for wildlife to be subjected to spray. Herbicides would not be applied using broadcast techniques in any zone. In addition, if any animals were to eat sprayed vegetation, the herbicides used, in general, do not bioaccumulate, although one study showed a slight increase in intestinal cancer in sheep grazing on picloram-treated pastures (Appendix B).

The Herbicide Information Profiles in Appendix B describe how toxicity for mammals, birds, and aquatic species is calculated. The dosages for different toxicity levels vary by wildlife type and method of exposure.

Dicamba is slightly toxic to mammals but does not bioaccumulate. With current use patterns, dicamba is not hazardous to endangered animals.

Glyphosate is practically non-toxic to birds and mammals and is practically non-toxic to bees. The Environmental Protection Agency identified one species of toad and one beetle species that may be endangered by glyphosate use, but these species are not found in the project area.

Picloram is practically non-toxic to birds and bees, and is slightly toxic to practically nontoxic in mammals and some species of fish. It has not been tested for chronic effects in wildlife species. It may be hazardous to some endangered invertebrates if applied to areas where they live; however, no endangered invertebrates have been identified for this project and picloram would not be used in riparian areas where the sensitive invertebrate species live.

Triclopyr is slightly toxic to mammals and birds, and practically non-toxic to bees. Wildlife mammals have not been studied to determine its acute or chronic effects. Laboratory studies show that Garlon 4 (a formulation of triclopyr), applied directly to water and artificially maintained for 96 hours at a concentration equal to 2 quarts per acre, is potentially harmful to aquatic organisms. Although studies in the natural environment have been unable to reproduce the laboratory effects, triclopyr is not used near water. The Environmental Protection Agency (EPA) has not determined if triclopyr is hazardous to endangered animals.

Fish and aquatic birds and animals may be present in the R zone. They are not likely to be adversely affected by herbicide use in this zone because only Rodeo ${ }^{\mathrm{TM}}$ formulation of glyphosate, which is "practically non-toxic to fish" (Appendix B), would be used in cutstump treatments in the R zone. (Although Rodeo ${ }^{\mathrm{Tm}}$ is labeled for use immediately adjacent to water, a 3-m [10-ft] no-herbicide buffer would be maintained along stream banks.) As a result, herbicides would not contaminate water used by aquatic species or wildlife. The project is not expected to significantly change the amount of shade at streamsides, so aquatic species would not be affected by warmer water temperatures.

In STC zones (about $2.1 \mathrm{~km}$ [1.3 mi]), in which little or no vegetation management activity would occur, fish and wildlife would not be affected. 
Effects on Endangered, Threatened and Sensitive Wildlife. Although the existing right-of-way crosses spotted owl dispersal habitat and some reproductive and foraging habitat, only small numbers of trees (fewer than 10 per acre) would be felled and the canopy closure and thermal regulation of the stand would remain unchanged. Consequently, the project would not affect spotted owls or their habitat (Larson, 1998).

No nesting peregrine falcons have been located within the project area. Although potential peregrine nesting habitat is near the project area, no vegetation removal is planned within $0.4 \mathrm{~km}(0.25 \mathrm{mi})$ of this habitat (Larson, 1998).

The northern bald eagle is found within the Columbia River Gorge during breeding and wintering months, but no nesting or winter roosting bald eagles have been located within the project area (Larson, 1998). Winter roosting habitat may exist, but would not be affected because few if any trees likely to be used for roosting would be cut. In addition, vegetation management activities would take place at a time of year when eagles normally are not present.

Region 6 Sensitive Species would not be adversely affected because the habitats where they are expected to be found are not areas that would be treated.

\subsubsection{Status Quo}

Similar to the Proposed Action, wildlife would be temporarily disturbed by workers manually cutting vegetation. However, disturbance would occur more often than for the Proposed Action. Based on past experience, workers would be in the area for several days at least once a year; depending on growth conditions, they may have to enter some sections twice a year. The Status Quo alternative would have no impact on the endangered and threatened trout, steelhead and salmon species because the treatment methods would not change conditions in the Columbia River or tributary streams. Region 6 Sensitive Species would not be adversely affected because the habitats where they are expected to be found are not areas that would be treated.

Potential effects on fish and wildlife from herbicides would not occur because herbicides would not be used.

\subsection{Soils}

The Columbia River Gorge formed when the Columbia River cut through the Cascade mountains. Part of the Cascade Range uplift, the area is characterized by deeply dissected mountains, steep slopes, and rock outcrops. Soils have developed on steep mountain slopes in materials derived primarily from basalt and andesite and mixed with a small amount volcanic ash (USDA-SCS, 1983, USDA-SCS, 1981). Rock outcrops and cliffs are common and soils are often cobbly. Erosion is active in much of the region and areas of recent mass movement are evident.

Vegetation management can affect soil characteristics such as available soil moisture, nutrient supply, erosion, and slope stability. The amount and severity of impacts is influenced by the vegetation management methods employed. The reduction of viable plant cover due to manual or chemical treatments could result in slight localized 
reductions in soil infiltration, the amount of water absorbed by plants, and increased surface run-off, erosion, and off-site movement of sediment. Increased sediment yields could adversely affect other resources including water quality, fish and wildlife, recreation, and vegetation. Herbicides can also affect soil productivity by inhibiting soil microbial activity and the growth of non-target plants.

\subsubsection{Proposed Action}

Where vegetation is removed or cleared, a slight increase in run-off and some localized erosion and soil movement could occur. Use of manual controls would cause little or no soil disturbance, although the degree of impact would be related to the amount of ground cover affected. Impacts would be alleviated when desirable vegetation becomes established. Clearing near riparian areas could cause minor amounts of sediment to enter streams if the ground surface is disturbed during tree felling or brush removal.

Soil-related impacts from the IVM program's recommended herbicide treatments would be limited and short-term. Herbicide effects depend on their chemical properties and how they interact with the environment. This interaction determines the mobility and persistence of the chemical in the soil environment. All the prescribed herbicides are non-toxic or only slightly toxic to soil microorganisms. Soil microbes are able to break down all of the recommended herbicides. Picloram can stay active in the soil for a moderately long time depending on soil conditions and may exist at levels toxic to plants for more than a year after application at normal rates. Alkaline conditions, fine textured clay soils, and a low density of plant roots can increase picloram's persistence (USDAFS, et. al.). However, surface soils within the affected corridor are neutral to moderately acidic, medium textured with many coarse fragments, and have prevalent roots. Under normal conditions, long-term buildup of picloram or any of the prescribed herbicides in the soil would be impaired.

The use of biological controls, in particular the successful establishment of low-growing plant communities within the existing corridor, would prevent the need for frequent corrective vegetation management activities. This would reduce or eliminate the longterm disruption of vegetation cover and soils associated with recurrent vegetation : management activities. Soils would not be directly affected by the use of biological 'agents.

In summary, soils impacts of the IVM alternative would be low in intensity but recurrent with successive vegetation treatments. The proposed action, using IVM with herbicides, minimizes disturbance to groundcover and soil. 'Once low-growing ground cover is established, recurrent impacts from future corrective vegetation treatments would be eliminated.

\subsubsection{Status Quo}

Current.vegetation management practice uses only manual clearing methods. Impacts are similar to the those described for the manual methods in the IVM proposal. However, on steep erodible soils where manual clearing is used instead of herbicides, erosion and sedimentation could be slightly greater than the Proposed Action due to soil disturbance 
from workers removing vegetation and annually traversing steep slopes. Without the use of herbicides, vegetation re-establishes itself quickly and workers are required to return more often, resulting in more trampling and disruption to soils. Overall, impacts would be low in intensity and recurrent with successive vegetation treatments.

\subsubsection{Mitigation}

For both alternatives, if vegetation treatments remove groundcover, the site would be seeded or planted to acceptable low-growing plant species as soon as practicable in order to prevent erosion. Riparian vegetation would not be disturbed if it is not a threat to transmission line reliability.

\subsection{Water Resources}

The Bonneville-Hood River transmission line traverses, rugged terrain dissected by steep drainages. The corridor crosses 15 perennial and 8 intermittent streams. These streams are high-energy, steep gradient waterways which flow into the Columbia River, which is less than 0.8 kilometer $(0.5$ mile) from the transmission line for most of the length of the right-of-way. The streams do not support adjacent wetland plant communities, and there are no floodplains on or adjacent to the right-of-way.

Section 303(d) of the 1972 federal Clean Water Act requires each state to identify those waters where existing pollution controls are not effective enough to achieve the state's water quality standards. The Columbia River is listed, according to Section 303(d), as water quality limited. From. Bonneville Dam to The Dalles Dam the river is listed as exceeding the summer temperature and total dissolved gas standards set for its surface water classification. Resident fish and aquatic life, and salmonid fish spawning and rearing, can be impaired by exceeding these parameters (Oregon DEQ, 1996). No municipal surface water or groundwater sources are crossed by the proposal.

Potential impacts of vegetation management methods on surface water quality include increased sediment yields, herbicide contamination, and increased stream temperatures. Disruption of the soil surface and vegetation increases surface run-off, erosion susceptibility, and the likelihood that soil and herbicides would be transported off-site. Surface waters could also be affected by accidental direct contact from herbicides. Under certain environmental conditions, herbicides can leach through the soil and contaminate groundwater resources. Clearing streamside vegetation increases a stream's exposure to sunlight, possibly raising water temperature.

\subsubsection{Proposed Action}

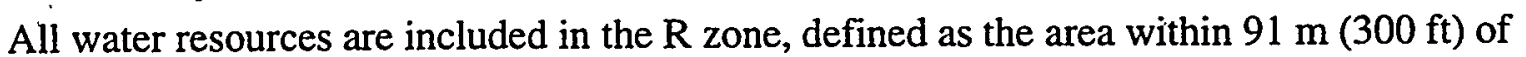
any surface water. $\mathrm{R}$ zone widths and buffer areas for sensitive resources were determined according to the Standards and Guidelines of the Northwest Forest Plan and the Oregon Forest Practices Act.

Within riparian zones all herbicide treatments, except cut-stump treatments using Rodeo $^{\text {TM }}$ formulation of glyphosate, would be precluded. Although Rodeo ${ }^{\mathrm{TM}}$ is labeled for control of plants growing in or immediately adjacent to water, it would not be used 
within $3 \mathrm{~m}$ (10 ft) of a water resource to comply with Oregon Forest Practice Rules (OAR-629-620-400). Rodeo ${ }^{\text {TM }}$ is strongly adsorbed by the soil where it is generally not active because residues are not easily released. If contaminated sediments were transported to surface waters, residues would not adversely affect water quality as a result of routine herbicide application. Broadcast foliar methods are not allowed in any zone, so there is little likelihood of direct contamination of surface water from herbicide spray.

Any amount of applied herbicide that is not degraded, taken up by plants, volatilized, or adsorbed is subject to leaching or transport by surface flows. Because most herbicides move only short distances under normal conditions, the amount of chemical residue actually entering a stream from surface flow is affected by distance to the stream, infiltration and organic layer properties of the soil, and the rate of surface flow. Picloram and dicamba, which could be used in non-riparian zones, are susceptible to transport by surface waters and can leach into groundwater under certain conditions (USDA-FS, et. al.). Because of these properties and their persistence, picloram and dicamba would not be applied within $\mathrm{R}$ zones. Picloram can persist in the soil under some conditions, but soils on this project are not conducive to that effect (section 3.4.1). Because of the soil characteristics in this area, the chance of picloram and dicamba reaching ground or surface water is slight. A $91-\mathrm{m}(300-\mathrm{ft}) \mathrm{R}$ zone buffer between surface water and any zone allowing picloram and dicamba herbicide use is adequate to prevent their transport to water through the soil or via surface flow.

Both manual and chemical treatments could temporarily reduce viable plant cover, lower water interception and transpiration losses by plants, and increase overland and stream flows. The right-of-way crosses streams at roughly a perpendicular angle and has been previously cleared and maintained. The amount of new stream surface exposed by future vegetation management activities would be minimal and impacts on water temperatures would be insignificant. Impacts due to increased sediment levels and stream flows would be low and would be alleviated once desirable vegetation communities are established. Water quality of the Columbia River would not be further degraded because the proposal is not expected to more than temporarily and slightly increase sedimentation of tributary. streams.

Overall, the proposed action; using IVM and following the prescribed treatments, would have a low impact on water quality. Proper application and handling of herbicides would minimize the risk of chemical contamination of waters (see section 3.5.3).

\subsubsection{Status Quo}

The existing vegetation management practices use manual methods similar to those described in the proposed alternative. Impacts would be related to the amount of vegetation removed and the extent of surface soil disturbance.

A slight increase in erosion and sediment yields is expected where clearing'activities disturb the surface soil on steep terrain. Due to the area's steep terrain and high erosion risk, compared to the proposal, the existing practice of yegetation management without herbicides could slightly increase the erosion potential and the likelihood of sediment entering surface waters. The increased risk exists because workers would be required to 
return annually to keep vegetation within safe limits, thus causing disturbance more often. Impacts would be greatest immediately following treatment and would continue until. sufficient ground cover is re-established.

No herbicide treatments are currently used so there is no risk of chemical contamination of surface and ground waters. Similar to the Proposed Action, the amount of new stream surface exposed by future vegetation management activities would be minimal and impacts on water temperatures would be insignificant.

Overall, impacts of this alternative would be low.

\subsubsection{Mitigation}

For both alternatives, disturbance of vegetation cover would be minimized within riparian buffer zones to avoid surface disturbance, increased run-off, and off-site transport of sediment.

For the Proposed Action, herbicides would be applied only as directed in the IVM prescriptions and according to herbicide label and EPA registration directions. No herbicide would be applied within $3 \mathrm{~m}$ (10 ft) of a stream. The cleaning and disposal of pesticide containers and equipment would be done in accordance with applicable federal, state, and local laws and regulations, and in a manner which will safeguard public health, the beneficial uses of water, aquatic organisms, and wildlife.

\subsection{Visual and Recreational Resources}

The Columbia River Gorge is famous for its scenic qualities--that is why the National Scenic Area was established. As discussed in section 1.1, the Scenic Area legislation recognizes the existence of the Bonneville-Hood River transmission line and allows BPA to continue maintenance activities.

The line can be seen from numerous scenic and recreational sites on both the Oregon and Washington sides of the river, including hiking trails and highways, and from the river itself. The visual presence of the towers, conductors, and related hardware has remained the same throughout the life of the line and will continue to do so. However, the visual character of the right-of-way changes both seasonally and gradually over time as vegetation grows. Extensive clearing or widespread use of herbicides (as in broadcast spraying), could draw attention to the transmission corridor and conflict with the scenic resources of the Gorge.

\subsubsection{Proposed Action}

After a review of the CRGNSA Management Plan and the proposed vegetation management zones, as well as a field review, the Landscape Architect for the Scenic Area concluded that all sections of the project right-of-way that can be seen from visually sensitive sites have been included in the V zone (lands that have a significant visual resource). No broadcast or aerial application of herbicides would be allowed, thus eliminating the potential to create large areas of dead vegetation that would defract from the visual quality of the area. Although some plant species may change as desirable 
vegetation becomes established, the visual qualities of the right-of-way are not expected to change noticeably from current conditions.

\subsubsection{Status Quo}

The visual quality of the right-of-way would remain the same.

\subsection{Human Health and Safety}

Effects on human health and safety depend on the vegetation management technique used. The potential for exposure to health and safety effects also varies for workers versus forest residents and visitors.

BPA's vegetation management program is done under contract. While no maintenance worker accidents have occurred on the Bonneville-Hood River right-of-way, in 1997 one worker was killed and another seriously injured in accidents involving manual cutting methods on other rights-of-way.

\subsubsection{Proposed Action}

\subsubsection{Manual/Biological Methods}

Workers. Re-seeding activities and hand-cutting of unwanted vegetation often require workers to operate heavy or sharp equipment in steep, uneven terrain. This creates the potential for worker accidents. The IVM program is expected to reduce the risk of worker accidents because workers will be required to use chainsaws in steep, inaccessible terrain much less frequently than under the Status Quo alternative, especially in zones SS, $\mathrm{Z}$; and V. The 30-km (19-mi) right-of-way crosses about $26 \mathrm{~km}$ (16 mi) of these zones.

Forest residents and visitors. Manual and biological methods would not affect the health or safety of forest residents and visitors.

\subsubsection{Herbicides}

In its FEIS on herbicide use (USDA Forest Service, 1988), the USFS Region Six evaluated a range of health effects studies. The FEIS Quantitative Risk Assessment predicts the amount of human exposure--both to project workers and to the public--from typical forestry operations, and also from a large accidental spill. The Risk Assessment used this information to assess health risks from typical uses in forestry applications, which were compared to EPA standards of acceptable risk for human health effects. The FEIS risk assessment identified as "Moderate" or "High" any predicted risks from Forest Service operations that were greater than EPA standards. Specific mitigation measures were designed to reduce human exposure from these operations and are mandatory for every applicable project on National Forest lands.

BPA has relied on the USFS analysis for this EA. Because typical forestry operations tend to involve herbicide use on larger areas than the areas proposed for this right-of-way management project, the types and magnitudes of risk assessed by the USFS are in general expected to represent the worst case risk for BPA's proposal. 
The USFS health effects analyses for the herbicides proposed for use on this project have been compiled in "Herbicide Information Profiles" and are reproduced in Appendix B. Key conclusions from these profiles are summarized below.

Workers. Health effects to workers are divided into two categories: general health effects (ranging from eye and skin irritation to tumors; and reproductive effects (effects on workers' reproductive system or progeny). The following summarizes the risk of these types of health effects to workers for the four herbicides proposed for this project:

Dicamba and Glyphosate: General health effects: Low or negligible risk for all application methods.

Reproductive effects: Moderate risk for backpack spray and hack-and-squirt applicators.

Triclopyr: General and reproductive effects: Low or negligible risk for all methods except backpack sprayers, for which risk is moderate.

Picloram:

General and reproductive effects: Negligible risk for all methods.

Mitigation. Workers will follow label instructions for application of herbicides and for worker protection.

Forest residents and visitors. Because BPA does not propose to use aerial spraying of herbicides, the ground-based application methods proposed pose a negligible risk of health effects to forest residents and visitors. Herbicides used for this project would be pre-mixed and brought to the site in a backpack container. No herbicides would be stored at or near the site. Therefore, amounts at the site would be too small to pose a significant risk to human health in the event of a spill. As required by Federal Insecticide, Fungicide and Rodenticide Act (FIFRA), containers and equipment will be cleaned and disposed of in accordance with federal, state, and local laws and regulations.

For more detail on herbicides and their human health effects and mitigation, see Appendix B.

\subsubsection{Status Quo}

\subsubsection{Manual Methods}

Workers: Current risks of accidents would continue or possibly increase as vegetation cover from repeated manual cuttings becomes more dense. Biological methods pose no risk to workers.

Forest residents and visitors: Manual and biological methods would not affect the health or safety of forest residents and visitors. 


\subsubsection{Herbicides}

Because herbicides would not be used, there would be no risk of health effects to workers or forest residents and visitors.

\subsection{Air Quality}

The Columbia Gorge Scenic Area is classified as a Class II airshed, which allows moderate degradation of air quality.

Air pollution sources associated with manual clearing include exhaust from hand-held equipment and from motorized vehicles, and periodic dust generated by off-road vehicle traffic. Use of herbicides could introduce harmful chemicals into the air.

\subsubsection{Proposed Action}

Exhaust from vehicles and machinery such as chain saws would be short-term.

Compared to existing conditions, the amount of exhaust would be reduced as the tall, fast-growing vegetation is controlled and replaced by low-growing plants and shrubs, thus reducing the number of return visits required for cutting. Dust from access road vehicle traffic would be short-term.

Herbicide spray in the air would occur in minimal amounts because only manual spot application techniques would be used. Application would also be limited to relatively calm periods (wind at less than $4 \mathrm{~km} / \mathrm{hr}(6 \mathrm{mph})$ and when temperatures ranged from 7 $24 \mathrm{C}^{\circ}\left(45-75^{\circ} \mathrm{F}\right)$, to minimize volatilization.

\subsubsection{Status Quo}

The small amount of exhaust and dust created by vehicles and machinery would be shortterm, although compared to the Proposed Action, the amount could be slightly greater due to the need for annual activity to keep tall-growing vegetation within safety limits.

Because herbicides would not be used, air contamination from herbicide spray would not occur.

\subsection{Other Effects}

There would be no change to land use with either alternative because the right-of-way is already established.

Cultural resources would not be affected because ground-disturbing methods, such as use of mowers, would not be used in either alternative. 


\section{CHAPTER 4 CONSULTATION, REVIEW; AND PERMIT REQUIREMENTS}

\section{National Environmental Policy}

This EA was prepared pursuant to the National Environmental Policy Act (42 U.S.C. 4321 et seq.) and implementing regulations, which require federal agencies to assess the impacts of their proposed actions on the environment. Based on information contained in the EA, a determination would be made that the proposal would either significantly affect the quality of the human environment, in which case an Environmental Impact Statement (EIS) is required; or that the proposal would not have significant impacts, permitting a Finding Of No Significant Impact (FONSI).

\section{Threatened and Endangered Species}

The Endangered Species Act of 1973 requires that federal agencies review the consequences of an activity on threatened or endangered species and the habitat on which they depend. The Columbia River Gorge National Scenic Area has determined that there would be no effect on any threatened or endangered wildlife species or its habitat (section 3.3). BPA concurs with this determination. No federally listed endangered or threatened plants were found in the project area (section 3.2).

\section{Federal Insecticide, Fungicide, and Rodenticide Act}

FIFRA (7 U.S.C. 136 et seq.) regulates the manufacture and use of pesticides, including herbicides. Under the Proposed Action, herbicides would be used to control unwanted vegetation and noxious weeds on BPA's right-of-way. Only EPA-approved herbicides would be used, and only according to manufacturers' directions. Only those herbicides approved for use by the Pacific Northwest Region of the Forest Service would be applied on Forest Service land in the project area. All label instructions pertaining to disposal would be followed. Herbicides would not be stored on the right-of-way and would be applied by licensed applicators only.

\section{Solid and Hazardous Waste}

The Resource Conservation and Recovery Act, 42 U.S.C. 6910 et seq. regulates the storage, use, and disposal of solid and hazardous waste. Domestic solid waste generated by maintenance crews during vegetation management activities (e.g., triple-rinsed herbicide containers, disposable clothing and gloves, broken cutting tools) must be disposed of in a state-approved sanitary landfill. BPA's maintenance crews would dispose of waste according to these regulations.

\section{Federal, State, Areawide and Local Plan and Program Consistency}

The existing project right-of-way is an authorized land use under an existing USFS Land Use Grant and easement agreements on state and private lands. Maintenance activities are subject to the requirements of these agreements, as well as to current environmental 
- laws. Right-of-way Land Use Grants are prepared in accordance with the requirements of the BPA/USFS 1974 Memorandum of Understanding (MOU). Right-of-way Management Plans were jointly prepared by BPA and the USFS under the terms of the MOU and the federal Land Use Grants. If a decision is made to proceed with the Proposed Action, the original management plans will be updated.

The proposal addresses environmental requirements in the USFS Mediated Agreement and the Northwest Forest Plan. The ecosystem standards and guidelines for management of habitat for late successional and old-growth forest-related species within the range of the northern spotted owl (Northwest Forest Plan) have been considered in developing proposed management zones and prescriptions.

Right-of-way maintenance and upgrades are specifically recognized as an accepted use in the CRGNSA Act.

\section{Floodplains and Wetlands, Safe Drinking Water Act}

No floodplains, wetlands, public water systems or sole source aquifers are crossed by the project right-of-way.

\section{Global Warming}

"Greenhouse gases," including carbon dioxide and methane (which contain carbon); absorb and re-radiate infrared radiation, preventing heat loss to space. Activities such as timber harvesting release carbon to the atmosphere and thus potentially affect global warming.

The proposed project would clear small trees and noxious weeds from $30 \mathrm{~km}(19 \mathrm{mi})$ of right-of-way. These trees and plants would no longer collect carbon; instead, they would release it as they degrade. The proposed amount of clearing is, however, insignificant to atmospheric carbon balance because the cleared trees are small and most of the noxious weeds contain little, if any, woody growth. In addition, low-growing vegetation would replace most of the cleared plants, thus replacing the carbon reservoirs. Therefore, this project would not contribute to global warming. 


\section{REFERENCES}

Columbia River Gorge Commission. 1992. Management Plan for the Columbia River Gorge National Scenic Area. White Salmon, Washington.

David Evans and Associates, Inc. March 1996. Prototype Integrated, Impact Avoidance Right-of-Way Management Plan, Hanford-Ostrander Corridor and North BonnevilleMidway Corridors, Columbia River Gorge National Scenic Area. Portland, Oregon.

Eastman, Donald. 1990. Rare and Endangered Plants of Oregon. Beautiful America Publishing Company, Wilsonville, Oregon.

Flora of North America Editorial Committee. 1993. Flora of North America North of Mexico, (Vol. 2, Pteridophytes and Gymnosperms). Oxford University Press, New

- York, New York.

Franklin, Jerry F. and Dyrness, C. T. 1973. Natural Vegetation of Oregon and Washington. Oregon State University Press, Corvallis, Oregon.

Hickman, J. C. 1993. The Jepson Manual: Higher Plants of California. University of California Press, Berkeley and Los Angeles, California.

Hitchcock, A., A. Cronquist, M. Ownbey, and J. Thompson. 1969. Vascular plants of the Pacific Northwest (Vol. 1-5). University of Washington Press, Seattle, Washington.

Hitchcock, Leo C., and A. Cronquist. 1973. Flora of the Pacific Northwest. University of Washington Press, Seattle, Washington.

Jolley, Russ. 1988. Wildflowers of the Columbia River Gorge. Oregon Historical Society, Portland, Oregon.

Kaye, Tom, 1997. Personal communication concerning the ability of Cimicifuga elata to persist in logged areas. Botanist, Plant Conservation Biology Program, Oregon Department of Agriculture, Salem, Oregon.

Kemp, Lois and Tim Butler. Mt. Hood National Forest Sensitive Plants and Noxious Weeds Field Guide. Mt. Hood National Forest, United States Department of Agriculture.

Oregon Department of Forestry. January 1997. Oregon Forest Practices Administrative Rules and Abridged Forest Practices Act.

Oregon Department of Environmental Quality. June 1996. Listing Criteria for 1994/96 Section 303(d) List.

Oregon Natural Heritage Program. 1995. Rare, Threatened and Endangered Plants and Animals of Oregon. Oregon Natural Heritage Program, Portland, Oregon. 
St. Hilaire, Kimberly. 1997. Bonneville - Hood River Line Right-Of-Way Threatened, Endangered and Sensitive Plant Species Survey. Unpublished report prepared for Bonneville Power Administration by David Evans and Associates, Inc. Portland, Oregon.

U.S. Department of Agriculture - Forest Service, U.S. Department of the Interior - Bureau of Land Management, U.S. Department Of Energy - BPA. Pesticide Fact Sheets.

U:S. Department of Agriculture - Forest Service. 1988. Final Environmental Impact Statement for Managing Competing and Unwanted Vegetation. Pacific-Northwest Region.

U.S. Department of Agriculture - Forest Service. 1991. Region 6 Sensitive Plant List. Portland, Oregon,

U.S. Department of Agriculture - Soil Conservation Service. January 1981. Soil Survey of Hood River County Area, Oregon.

U.S. Department of Agriculture - Soil Conservation Service. August 1983. Soil Survey of Multnomah County, Oregon.

U.S. Department of Energy - Bonneville Power Administration. September 1996. Columbia River Gorge Vegetation Management Final Environmental Assessment. DOE/EA-1162. Portland, Oregon. 


\section{PREPARERS AND CONTRIBUTORS}

Robin Dobson, Botanist, USFS, Columbia River Gorge National Scenic Area, provided information and review for the forest sensitive species biological evaluation.

Inez Graetzer, Environmental Specialist, BPA, is environmental project manager and conducted public involvement and inter-agency coordination.

Art Guertin, NEPA Coordinator, USFS, Columbia River Gorge National Scenic Area, provided guidance for Mediated Agreement consistency and reviewed the NEPA evaluation.

Elizabeth Johnson, Natural Resources Specialist, BPA, Redmond Region's project lead for vegetation management of transmission line rights-of-way, provided project information, land-owner coordination, and review of environmental analyses.

Virginia Kelly, Landscape Architect, Columbia River Gorge National Scenic Area, evaluated the visual impacts.

Linda Krugel, AICP, Planning Consultant, provided public involvement planning guidance and support.

Richard Larson, Fish and Wildlife Biologist, Columbia River Gorge National Sंcenic Area, prepared the biological assessment/evaluation for federally listed endangered and threatened fish and wildlife.

Kimberly R. St. Hilaire, Botanist and Wetlands Specialist, David Evans and Associates, Inc., conducted the surveys for threatened, endangered and sensitive plants and was the principal author of the biological evaluation for plants.

Philip Smith, GIS Specialist, National Systems \& Research Information (NRSI), Inc., was responsible for soils and water resources analyses.

Doug Wittren, GIS Analyst, National Systems \& Research Information (NRSI), Inc., compiled information from multiple inter-agency databases to map the resources and vegetation management zones.

Judith Woodward, principal, Phillips, Woodward \& Associates, edited the EA. 
Appendix A Public Comments 


\section{Telephone Conversation Record}

November 7, 1997

Re: Comments on Proposed Bonneville-Hood River Vegetation Management EA as noted in Scoping Letter of 10/27/97

From: Norbert Kiedrowski

131 16th St

Washougal, WA

360-835-2965

To: Inez Graetzer

RECEIVED BY BPA

PUBLIC INVOLVEMENT

LOG\#: BPA HOD - OR - 001

RECEIPT DATE:

Mr. Kiedrowski called BPA's 1-800 number to ask that we return his call so that he could give us some information pertaining to our proposed use of chemicals. I returned the call on 11/7/97.

Mr. Kiedrowski owns a 20-acre parcel of land in Cascade Locks, along the Frontage Road south of I-84. His property borders the west side of the Hatchery (to the east.of him) and the Cascade Locks city water reservoir is to the west of his property. There is a 3-acre lake on his property. which contains fish. His concern is about chemicals possibly washing into the small intermittent stream that feeds the lake on his property and getting into their lake.

I explained the specific methods that we would be using for chemical application --basal, cut stump, and specific foliar--and he said that he didn't think that it would be a problem, but he wanted to be sure that we knew the lake was there.

I thanked him for the information and his comments and told him that this conversation record would be entered into the official log for scoping comments for the project.

He then asked whether I knew who he could contact to ask about some work that his neighbor : was doing upslope of him (to the south) that seemed to be diverting water from the stream and his lake. I provided the number of the DEQ office at The Dalles for in-stream work issues, and the OR Dept. of Water Resources 1-800 number to find out about any water rights issues. He thanked me for the information and for calling him back. 
BPA Public Involvement Office

ACS

P.O. Box 12999.

$\cdot$ Portland, OR 97212

To Whom It May Concern;

I am responding to document $\mathrm{ECN}-4$, a proposal to clear unwanted vegetation on BPA right-of-way in Hood River. Thank you for making me aware that this is being planned.

I own and operate a small organic market garden on my property, which is located directly east of Mitchell Point. The power line runs above my property on state and privately owned property. However, because of the nature of nature (and hydraulics) I would be directly -affected by the use of chemicals to undertake the task proposed.

I received a similar letter approximately 5 years ago, responded similarly and was granted an agreement that no chemical application would occur in the right-of-way that crosses above our property. This stretch starts at the saddle of Mitchell Point and runs easterly to the next ridge before dropping into Post Canyon. I sincerely hope that we can come to the same agreement now and in the future.

I am sending a copy of this letter to Inez Graetzer as well, in hopes that my agricultural interest in the area can be included in the Environmental Assessment as a semi-permanent location for future reference.

.. . Thank you for your time and consideration. I look forward to hearing from you soon.

Most Sincerely,

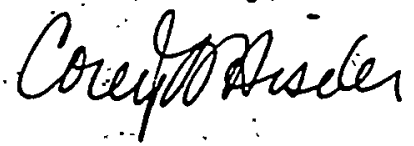

- Corey L. Hiseler. 


\section{BPA Public Involvement}

$\begin{array}{lll}\text { From: } & \text { Foxes } & : \\ \text { To: } & \text { comment@bpa.gov }: \\ \text { Subject: } & \text { Vegetation management project ECN-4 } \\ \text { Date: } & \text { Friday, October 31, 1997 9:53AM }\end{array}$

19621419036201

llona S Fox

HC 66 Box 690

Cascade Locks, OR 97014-9702

Our concerns as property owners under the BPA lines relates to our business. We provide horseback rides that leave from our property and continue on to National Scenic Area. Sections of our trail are near the power lines that you will be clearing and spraying. It would be a help to us to be able to know when you would be doing such work in our area so we could try to avoid contact with you (no offense meant)! Chain saws and chemical odors do not mix well with what we try to portray in the Gorge to our customers.

We would appreciate any consideration you can accord us, and we in tum will of course do the same.

Thank you. Ilona S. Fox

RECEIVED BY BPA

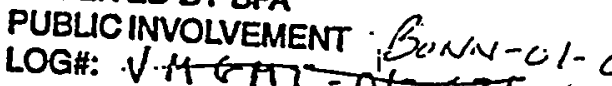
RECEIPT DATE: 


\section{Appendix B Herbicide Information Profiles}




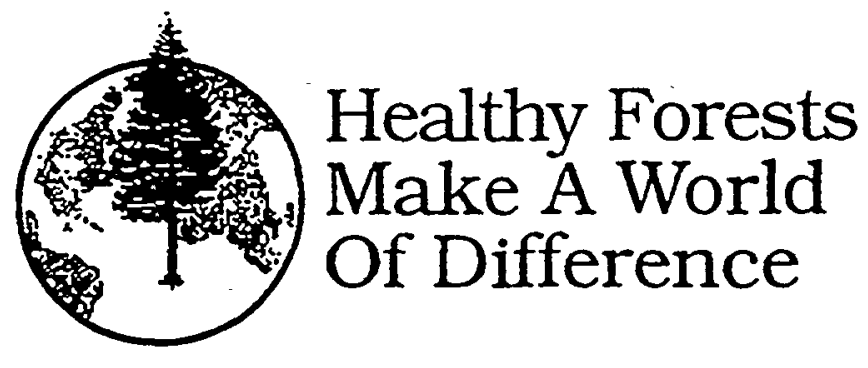

\section{Glyphosate \\ Herbicide Information Profile}

This information profile is produced by the USDA Forest Service, Pacific Northwest Region, for employees, forest workers, and for the public. It provides information on forest and land management uses, environmental and human health effects, and safety precautions for the herbicide glyphosate and its formulations. A list of definitions is included in Section VIII of the information profile. For general information on herbicide use by the Forest Service, refer to the PNW Region Treatment Methods Profile for Herbicides.

The principal sources of information and findings in this profile are the PNW Region FEIS (Final Environmental Impact Statement) for Managing Competing and Unwanted Vegetation; Forest Service "Herbicide Background Statement: Glyphosate"; and product labels and Material Safety Data Sheets. Information from other sources is specifically referenced.

Beginning in 1992, the PNW Region publishes a bibliography of recent anecdotal and scientific accounts, and analyzes reported worker health effects. This herbicide information profile has been updated to reflect new information from a review of new literature through 1991. plus a few more recent studies submitted to the Forest Service.

\section{BASIC INFORMATION}

COMmon Name: Glyphosate

Chemical Name: N-(phosphonomethyl) glycine

Common Product Names: Rodeo ${ }^{\circledR}$, Accord $^{\otimes}$. Roundup ${ }^{\otimes}$

Pesticide Classification: Herbicide

Registered Use Status: "General Úse"

Formulations: Commercial glyphosate products generally contain one or more inert ingredients. An inert ingredient is anything added to the product other than the active plant-killing ingredient. The names of inert ingredients are not usually listed on the label. The contents of three glyphosate formulations are listed below:

$\begin{array}{lr}\begin{array}{l}\text { Rodeo }^{\oplus} \\ \text { glyphosate }\end{array} & 53.5 \% \\ \text { water } & 46.5 \% \\ \begin{array}{l}\text { Accord } \\ \text { glyphosate }\end{array} & 41.5 \% \\ \quad \text { water } & 58.5 \% \\ \text { Roundup } & \\ \text { glyphosate } & \\ \text { related organic acids of glyphosate } & 1.0 \% \\ \text { isopropylamine } & 0.5 \% \\ \text { polyethoxylated } & \\ \quad \text { tallow amine surfactant } & 15.4 \% \\ \text { water } & 41.6 \%\end{array}$


Rodeos and Accord " lormulations of glyphosate require adding other chemicals, called surfac- . tants, for some labeled uses. Entry II is a surfactant which consists of the same inert ingredients found in Roundup ${ }^{3}$. Therefore, Roundup ${ }^{\circledR}$ formulation information in this profile also characterizes potential effects from Accord ${ }^{\circledR}$ plus Entry II used in Forest Service applications.

Other surfactants that can be used with Rodeo ${ }^{\circledR}$ - or Accord ${ }^{\otimes}$ are listed on the label. This profile does not discuss any possible effects on the human environment from using other surfactants in Forest Service applications of Rodeo ${ }^{\circledR}$. or Accord $^{\Phi}$. The PNW Region has not reviewed these surfactants for potential effects on the human environment.

RESIDUE Assay Methods: Gas/liquid chromatography and high performance liquid chromatography methods are available for residue assay. In laboratory tests. an average of 82 percent of known glyphosate concentrations was recovered. New detection methods report $1.0 \mathrm{ppb}$ detection limit, using simpler and shorter processes. (Oppenhuizen and Cowell, 1991).

\section{Herbicide Uses}

Registered Forestry, Rangeland, Right-ofWAY USES: Planting site preparation, conifer release, forest nurseries, rights-of-way and facilities maintenance, and noxious weed control. Rodeo $o^{\otimes}$ is labeled for control of plants. growing in or immediately adjacent to water.

\section{Operational DetaILs:}

TARGet Plants: Glyphosate is used to control grasses, herbaceous plants, including deep rooted perennial weeds, brush, some broadleaf trees and shrubs, and some conifers. Glyphosate does not control all broadleaf woody plants. Timing is critical for effectiveness on some broadleaf woody plants and conifers.
Monl: (2) ACrus: Glyphosate is applied to foliage. It is ahsorhed by leaves and rapidly moves through the plant. Glyphosate prevents the plant from producing amino acids that are the huilding blocks of plant proteins. The plant. unable to make proteins, stops growing and dies. Glyphosate is metabolized or broken down by some plants. while other plants do not break it down. AMPA (aminomethylphosphonic acid) is the main break-down product of glyphosate in plants.

METHOD OF APPLICATION: Aerial spraying, spraying.from a truck, backpack or hand-held sprayer; wiper application; frill treatment; cut stump treatment. and by cartridge injecting lance $\left(E-Z-J_{e c t}{ }^{\circledR}\right)$.

USE RATES: 0.3 to 4.0 pounds of active ingredient per acre.

\section{Special Precautions:}

Always read all of the information on the product label before using any pesticide. Read the label for application restrictions.

Timing of Application: Apply after leaves expand fully but before fall color change.

DRIFT CONTROL: Do not allow careless application or spray drift. Do not permit spray or spray drift to contact desirable plants.

\section{EnVironmental Effects/Fate}

SoIL:

RESIDUAL SOIL ACTIVIT: Glyphosate does not have herbicidal properties once it contacts soil. It is not absorbed from the soil by plant roots.

A related chemical, called $\mathrm{N}$-nitrosoglyphosate or NNG. has been detected in test soils after applying glyphosate at five times the normal use rate. No studies have found conclusive evidence of NNG production using-normal application rates. (Khan and Young. 1977: Newton. et. al.. 1984) 
AISSORP TION: Glyphosate and the surfactant used in Roundup ${ }^{*}$ are both strongly adsorbed by the soil.

Persistinct: and Agents of Degradation: Glyphosate remains unchanged in the soil for varying lengths of time, depending on soil texture and organic matter content. The halflife of glyphosate in soil can range from 3 to 249 days. Soil microorganisms break down glyphosate. The surfactant in Roundup ${ }^{\circledR}$ has a soil half-life of less than 1 week. Soil microorganisms break down the surfactant.

\section{Metabolites/Degradation Pronucts and} Potential Environmental Effects: The main break-down product of glyphosate in soil is AMPA (aminomethylphosphonic acid), which is broken down further by soil microorganisms. The main break-down product of the surfactant used in Roundup ${ }^{\circledR}$ is carbon dioxide.

\section{WATER:}

SoLuBILITY: Glyphosate dissolves easily in water.

POTENTIAL FOR LEACHING INTO GROUND-WATER: The potential for leaching is low: Glyphosate and the surfactant in Roundup ${ }^{\oplus}$ are strongly adsorbed to soil particles and are not easily released back into water moving through soil. Monitoring found neither glyphosate nor AMPA were susceptible to leaching after a forest application in British Columbia (Feng and Thompson, 1989).

SURFACE WATERS: Test shows that the halflife for glyphosate in water ranges from 35 to 63 days. The surfactant half-life ranges from 3 to 4 weeks. Studies examined glyphosate and AMPA residues in surface water after forest application in British Columbia with and without no-spray streamside zones. With a no-spray streamside zone. very low concentrations were sometimes found in water and sediment after the first heavy rain. Where glyphosate was sprayed over the stream. higher peak concentrations in water always occurred following heavy rain. up (1) 3 weeks ąter application. Glyphosate and A.MPA residues peaked later in stream sediments. where they persisted for over 1 year. Thesc residues were not easily released back into the water. (Wan, 1986).

AIR:

Volatilization: Glyphosate does nọt evaporate easily.

POTENTIAL FOR By-PRODUCTS FROM BURNING OF TREATED Vegetation: Major products from burning treated vegetation include phosphorus pentoxide, acetonitrile, carbon dioxide and water. Phosphorous pentoxide forms phosphoric acid in the presence of water. None of these compounds is known to be a health hazard at the levels which would be found in a vegetation fire.

\section{Ecological EFFECTS}

\section{Soll Mícroorganisus:}

Most studies have shown no adverse effects on soil microorganisms, including soil nitrogen cycling processes. (USDA-FS, 1984) One study found a significant reduction in nitrogen fixation by bacteria associated with clover that was planted in a sandy soil 120 days after glyphosate was applied. The authors could not conclude whether the reduction was due to direct glyphosate effects on the bacteria, or on plant processes that support nitrogen fixation. (Eberbach and Young, 1983) Monitoring of Roundup ${ }^{\otimes}$ application to British Columbia forest soils found no long-term effects to any soil animals or microorganism populations over six months. Some populations were reduced after spraying but recovered within thirty days. (Preston and Trofymow. 1989). Monitoring of pine seedlings and associated mycorrhizal lung $\mathrm{i}$ found no effect on seedling growth or ectomycorrhizal development following field applications of glyphosate in Ontario. Canada. 
(Chakravariy, P. and Chartapaul. L. 199()).

Plants:

Contact with non-target plants may injure or kill plants. Roundup ${ }^{\omega}$ was not toxic to algae species in British Columbia forest streams at post-spray levels. and appears to act as a source of phosphorus for algal growth where the nutrient is in short supply. (Austin et al., 1991).

\section{Aquatic Animals: .}

Glyphosate is no more than slightly toxic to fish, and practically non-toxic to aquatic invertebrate animals. It does not build up (bioaccumulate) in fish. A misprinted concentration in fish fillets in one published study has caused confusion. (Folmar, 1984)

The Accord ${ }^{\circledR}$ and Rode $^{\circledR}$ formulations are practically non-toxic to freshwater fish and aquatic invertebrate animals. The Roundup ${ }^{\circ}$ formulations is moderately to slightly toxic to freshwater fish and aquatic invertebrate animals. Glyphosate and its formulations have not been tested for chronic effects in aquatic animals. Acute toxic levels are:

\section{RODEO® AND ACCORD®}

\section{species}

fish

invertebrates

RoUNDUP@

species

fish

invertcbrates

\section{LC50}

$>1,000 \mathrm{ppm}$

$930 \mathrm{ppm}$

5 to $26 \mathrm{ppm}$

4 to $37 \mathrm{ppm}$
LC50
TERRESTRIAI. ANIMALS:

Glyphosate is practically non-toxic to birds and mammals. It is practically non-toxic to bees.

Acute toxic levels are:

\section{GLÝPHOSATE}

species

bobwhite quail.

bee

\section{LD50}

$3,850 \mathrm{mg} / \mathrm{kg}$

$>100 \mathrm{micrograms} / \mathrm{bee}$
No significant effects on survival and reproduction of deer mice and Oregon voles were observed over five years following Roundup ${ }^{\oplus}$ release treatment of Douglas-fir plantations in British Columbia. Roundup ${ }^{\Phi}$ had little or no direct effect on development of young mice or vole populations; however possible health effects on individual animals were not directly studied (Sullivan, 1990).

In mammals, most glyphosate is excreted, unchanged, in urine and feces. Glyphosate was not broken down in rats given oral doses, and it did not bioaccumulate (Brewster et al, 1991).

Glyphosate and its formulations have not been tested for chronic toxicity on wildlife species. Testing on laboratory mammals of glyphosate and its formulations are reported in Section V.

\section{Threatened ANd ENDANGered SPECIES:}

Glyphosate may be a hazard to endangered plants if it is applied to areas where they live. EPA identified 76 species that may be endangered by glyphosate use, including 74 plant, one toad and one beetle species. 


\section{Health Effects Testing:}

These data are results of laboratory animal studies. These data have been evaluated by the Forest Service and are used to make inferences rclative to potential human health effects.

For glyphosate and its formulations, findings are from studies conducted by the manufacturer. These studies have been presented to EPA to support product registration, but may not be available to the public.

For glyphosate, the Environmental Protection Agency has evaluated these studies during the registration process. For Roundup ${ }^{\circledR}$ formulation, the findings are from studies supported by the manufacturer that are cited in the Material Safety Data Sheet. The Rodeo@ and Accord® formulations, which consist of glyphosate and water only, are not expected to cause any greater health effects than concentrated glyphosate.

\section{AcuTE Toxicity:}

Acute Oral Toxicrty; tests in male and female rats

\section{GLYPHOSATE}

Median lethal dose: $4,320 \mathrm{mg} / \mathrm{kg}$.

Slightly Toxic (Category III)

\section{ROUNDUP@ FORMULATION}

Median lethal dose: $5,000 \mathrm{mg} / \mathrm{kg}$.

Slightly Toxic (Category III)

Acute Der.mal Toxicity; tests on rabbits

\section{GLYPHOSATE}

Median lethal dose (males): $5,010 \mathrm{mg} / \mathrm{kg}$ (females): $794 \mathrm{mg} / \mathrm{kg}$

Slightly Toxic (Category III)

\section{ROUNDUP® FORMULATION}

Median lethal dose: $>5,000 \mathrm{mg} / \mathrm{kg}$

Practically Nontoxic (Category IV)
Primari Skin Irritation: tests on rabbits

GLYPHOSATE

Not an irritant. (Category IV)

ROUNDUP® FORMULATION

Slightly Irritating (Category III)

Primary Eye Irritation; tests on rabbits;

GLYPHOSATE

Mild eye irritant. (Category III)

ROUNDUP@ FORMULATION

Moderately irritating (Category II)

Acute INHALATION-this requirement was waived by the EPA for glyphosate.

ROUNDUP@ FORMULATION

Median lethal concentration: $3.18 \mathrm{mg} / 1$

(Rat)

Slightly Toxic (Category III)

\section{Chronic Toxicity:}

These data are also based on tests in laboratory animals. EPA requires chronic toxicity tests only for the active ingredient glyphosate. Reports of Roundup ${ }^{\oplus}$ formulation testing are from the MSDS (Material Safety Data Sheet).

Please refer to Section $X$ for an explanation of how NOEL (No Observable Effects Level) is calculated.

The Pacific Northwest Region FEIS risk assessment evaluated the quality of the testing that had been done for glyphosate up to 1988 . Quality consideration for individual studies included: ranges of doses and species that were tested; length of test; identification of the most sensitive effect. Additionally, the degree of quantitative agreement among all tests for an effect was considered. Please refer to Section $X$ for an explanation of qualitative ratings in this section. 


\section{SYSTEMIC Toxicity:}

NOEL for glyphosatc: $31 \mathrm{mg} / \mathrm{kg} / \mathrm{day}$ (rat): 20 $\mathrm{mg} / \mathrm{kg} /$ day (dog)

The PNW Region FEIS rated the quality of testing as Marginally Adequate: the dose at which effects are seen in animal studies varies widely.

After repeated skin exposure for three weeks to Roundup ${ }^{\circledR}$ formulation at five times recommended use concentration, severe skin irritation and systemic toxic effects were observed in rabbits. Slight to moderate skin irritation was the only effect in rabbits treated with three times recommended use strength.

\section{CarcinogenictTy:}

The PNW Region FEIS rated the quality of testing as Marginally Adequate, and assumed that glyphosate could cause cancer. Since the 1988 rating, EPA has concluded that glyphosate should be classified as having evidence of noncarcinogenicity for humans. There was no convincing evidence of carcinogenicity in new studies in two animal species. (Dykstra and Ghali, 1991)

Glyphosate was negative in 'tests for mutagenicity (the ability to cause genetic damage).

\section{REPRODUCTION/DEVELOPMENTAL:}

The PNW Region FEIS used a NOEL of $10 \mathrm{mg} /$ $\mathrm{kg} / \mathrm{day}$, based on kidney effects observed in rat pups. This NOEL was accepted by the EPA for developmental effects; however, EPA has changed their estimated NOEL recently (USEPA, 1993a and 1993b). A new study did not find any kidney effects in rat pups fed larger doses of glyphosate over similar lengths of time. EPA concluded that the kidney effects observed in the earlier study were not glyphosate-related (US-EPA, 1993a).

The EPA now considers the NOEL for developmental effects from glyphosate to be $175 \mathrm{mg} / \mathrm{kg} /$ day, a dose 17.5 times larger than the previous estimate. The new NOEL is based on ohserved diarrhea. nasal dischargc. and death observed in rabibits given larger doses (US-EPA. 1993h).

The PNW Region FEIS evaluated the testing as Marginally Adequate for these effects.

\section{ImMUNe Systein EfFects}

The PNW Region FEIS evaluated the testing as Inadequate for these effects.

\section{Nervous System EFFects}

The PNW Region FEIS evaluated the testing as Inadequate for nervous system effects.

\section{Human Health EFfects}

\section{Forest Service Evaluation of Human Health} Risks:

The Pacific Northwest Region evaluated a range of glyphosate health effects data, including some laboratory studies cited in Section V. Both quantitative (numerical) estimates of toxicity, and the quality of data used to make numerical estimates were evaluated. The new information cited in Section V would improve the "quality of information" ratings. No new studies indicated a reduced margin of safety which would warrant additional restrictions on use of glyphosate beyond those specified in the FEIS.

Two new studies (US-EPA, 1993a\&b); and Middendorf, 1993) indicate that the margin of safety for the public and for some workers may be 'greater than' estimated in the PNW Region FEIS. FEIS ratings may overstate risks, based on the new information.

The FEIS Quantitative Risk Assessment predicts the amount of human exposure-both to project workers and to the public-from typical forestry operations, and also from a large accidental spill. The Risk Assessment used this information to assess health risks from typical uses. These risks were compared to EPA standards of acceptable risk for human health effects. The FEIS risk 
assessment identified as "Moderate" or "High" any predicted risks from Forest Scrvice operations that were greater than EPA standards.

Specific mitigation measures were designed to reduce human exposurc from these opcrations: they are mandatory for every applicable project on National Forest lands.

The complete set of risk ratings is displayed in Sec. X.

The quality of the existing data affects the reliability of these risk ratings. The FEIS judged the overall quality of available data on glyphosate toxicity to be "Marginal". There were studies of adequate quality and results did not vary greatly, but more information would increase reliability. Although new studies may change estimates of health effects, the results are considered moderately reliable.

\section{Potential for Health Effects to the Public:}

Forest visitors and nearby residents could be exposed to herbicide drift, to vegetation with herbicide residues, and to accidental spraying. They also could eat food or drink water containing herbicide residues.

No studies of public exposure to forest herbicide applications were available. Public doses were estimated based on the behavior of the herbicide in the environment. "Routine Application" estimates maximum possible public exposure under normal operating conditions. The "Large Spill" situation models the highest doses that could ever be reasonably be expected to occur. Typical public exposures and risks would be much lower than either situation.

\section{Mitigating Measures to Reduce Glyphosate Risks to Public:}

"Low" risk of general health effects for all routine projects. "Moderate" risk of reproductive health effects for people who receive multiple exposures to glyphosate from a large (40)-acre) aerial application project. "Low" risk for śmaller (40)-acre) aerial projects. and for all ground- hased applications:

Consider potential for public exposure when designing contact procedures, posting and signing needs in the Herbicide Application Plan.

"Moderate" risk of general health effects, and "High" risk of reproductive effects if exposed to concentrated glyphosate from a large spill:

Prevent all public contact with accidental spills (emergency spill notification system, restrict public access to spill site).

\section{Probability of a Worker Receiving a Dose which Affects General Helath or REPRODUCTION:}

Worker exposure and dose are estimated for typical forestry applications. Worker doses do not account for any reduction in exposure from following safety precautions or mitigating measures (such as wearing protective clothing).

Studies are available that measure actual worker doses of herbicide for some typical forestry applications. Backpack applicators of Roundup ${ }^{\Phi}$ in forest plantations have been monitored for the doses they absorbed in actual spray operations (Middendorf, 1993). The measured doses for workers averaged $1 / 1000$ the amount that was predicted in the PNW Region FEIS for Routine applications, and 1/67 the amount predicted for a Worst-case application situation. The worker risks would be much lower than the estimates used if these new operational doses were substituted for doses predicted by PNW Region FEIS.

\section{Mitigating Measures to Reduce Identified GLYPHOSATE RISKS to WORKERS:}

The probability of worker exposure to a toxic concentration for general health effects was rated "Low" or "Negligible" for all application methods. The probability of worker exposure to a toxic concentration for reproductive effects was rated "Low" or "Negligible" for aerial and tank truck mixer/loaders; "Moderate" for backpack spray and hack-and-squirt applicators. 
In the PNW Region FEIS. Mitigating Measure 13 requires workers applying any herbicide to wear protective clothing. Mitigating Measure 23 requires worker exposure monitoring for all herbicide application projects.

The 1992 Amendment to the ROD requires workers to review this Information Profile before agreeing to apply glyphosate herbicides. The worker may request reassignment without penalty. Additional personal protective equipment will be available at the worksite for workers who want to reduce their exposure to the herbicide.

\section{Acute Toxicity (Poisoning)}

REPORTED EFFECTS: Most incidents reported in humans have involved skin or eye irritation in workers after exposure during mixing, loading or application of glyphosate formulations. Nausea and dizziness have also been reported after exposure.

Swallowing the Roundup ${ }^{\circledR}$ formulation caused mouth and throat irritation, pain in the abdomen, vomiting, low blood pressure, reduced urine output, and in some cases, death. These effects have only occurred when the concentrate was accidentally or intentionally swallowed, not as a result of the proper use of Roundup ${ }^{\otimes}$. The amount swallowed averaged about 100 milliliters (about half a cup).

\section{Chronic Toxicity:}

Reported Effects: There are no reported cases of long term health effects in humans due to glyphosate or its formulations.

\section{Potential for Adverse Health Effects from INERT INGREDIENTS CONTAINED IN THE Forifulated Product:}

Inert ingredients found in glyphosate formulations may include water and a surfactant (polyethoxylated tallowamines). The surfactant is a skin irritant and a severe eye irritant in concentrate form (Entry II). The surfactant compounds are more diluted in water and less toxic in the Roundup formulation. The only incrt ingredient in Rodecos or Accórd" is water. which is considered nontoxic.

The manufacturer has identified the inert ingredients in glyphosate formulations to EPA and to the public. EPA classified all inerts into one of four categories, called "Lists". List 1 contains chemicals of known toxic concern. List 2 contains chemicals of suspected toxic concern which are high priority for testing. List 4 contains chemicals of known nontoxic character, generally recognized as safe to humans. All other chemicals were classified on List 3: Inerts of unknown toxicity. EPA did not find enough information available on the toxic properties of List 3 chemicals to classify them on Lists 1,2 , or 4 .

All inert ingredients used in Rodeo ${ }^{\circledR}$, Accord $^{\circledR}$, and Roundup ${ }^{\oplus}$ formulations were classified by EPA on List 3 or List 4.

\section{Health Effects of Exposure to Formulated Products:}

Because Accord ${ }^{\oplus}$ and Rodeo ${ }^{\otimes}$ contain water as the only inert ingredient, health effects are assumed to be no greater than those for pure glyphosate. The Roundup ${ }^{\circledR}$ formulation is moderately toxic, and may cause skin irritation and eye irritation. Effects of Roundup ${ }^{\oplus}$ characterize the effects expected for a spray mix of Accord ${ }^{\oplus}$ with Entry II surfactant; please refer to Section I, Formulations for details.

\section{Health Effects Associated with}

\section{Contaminants:}

Glyphosate contains the contaminant $\mathrm{N}$-nitroso glyphosate (NNG) at $0.1 \mathrm{ppm}$ or less. The potential for NNG to cause cancer is unknown. The EPA has not assessed the health risks of NNG. No carcinogenic effects were observed in tests of glyphosate; the EPA concluded these tests were evidence of noncarcinogenicity. (Dykstra and Ghali, 1991)

1.4-dioxane is a contaminant of surfactant in Roundup ${ }^{*}$. Dioxanes caused liver and kidney damage. and possible tumors in rats exposed (o) 
high levels $(10(1) 0 \mathrm{ppm}$ in water for tho years). These effects were not observed at lower exposure levels. or in other animal specics. (ACGIH. 1991.) The EPA decided that the reported trace level of 1.4 -dioxane (30) $\mathrm{ppm}$ ) in the Roundup ${ }^{\text {is }}$ formulation was not likely to result in unreasonable adverse health effects. Monsanto reports that 1.4-dioxane contamination has been further reduced to $23 \mathrm{ppm}$. (Monsanto Corp.

Undated(b)).

\section{Health Effects Associated with Other Formulations:}

Some formulations contain glyphosate mixed with other herbicides such as $2,4-\mathrm{D}$ or dicamba. This profile does not fully describe the potential for health or environmental effects from these formulations containing multiple herbicides. Additional information on properties and potential effects of these formulations will be prepared before they are used in the PNW Region.

\section{Societal Perceptions:}

Public opinion about herbicide use in general ranges from a perception that herbicides are completely safe, to a perception that they are very hazardous. A full range of opinion is available in the FEIS.

\section{Safety Precautions:}

Signal Word and Definition:

Roundup@: WATRING - Causes substantial but temporary eye injury. Harmful if inhaled.

Rodeo@: CAUTION - May cause eye irritation. May be harmful if inhaled.

Accord@: CAUTION - May cause eye irritation.
Protective Phechltions for Workers:

Avoid contact with eyes. skin or clothing. Avoid breathing vapors or spray mist. Wash thoroughly with soap and water after handling.

\section{Medical Treatment Procedures (Antidotes):}

There is no specific antidote for glyphosate: treat symptoms. For exposure to the eyes, flush with plenty of water for at least 15 minutes. Gct medical attention. For exposure to the skin, flush skin with plenty of water. In case of emergency: call your local poison control center for advice. .

\section{Handling, Storage and Disposal:}

Glyphosate is corrosive to unlined steel and galvanized steel. Do not mix, store or apply glyphosate in galvanized steel or unlined steel containers of spray tanks. Glyphosate is stable under normal storage conditions for at least 5 years. Wastes should be disposed of in a landfill approved for pesticide disposal or according to federal, state, and local rules. Do not contaminate water, food, animal feeds or seed by storage.

\section{Emergency (Spill) Hazards and Procedures:}

Spills that soak into the ground should be dug up and put in plastic lined metal drums for disposal. Spills on floors or other hard surfaces should be contained or diked. An absorbent clay should be used to soak up the spill. The contaminated absorbent should be put in plastic-lined metal drums. Drums of contaminated soil should be disposed.of in a landfill approved for pesticide disposal or according to federal, state and local rules. Do not contaminate water, food, animals feeds or seeds by disposal. In case of a large spill. call CHEMTREK at 1-800-424-9300 for advice. 


\section{DEFINITIONS}

acute toxicity - The amount of a substance, as a single dose. to causc poisoning in a tcst animal

adsorption - the process of attaching to a surface

basal treatment - applied to the siem of a plant just above the soil

bioaccumulate - the uptake of a chemical by an organism from its environment.

broadcast application - applied over an entire area

carcinogenicity - ability to cause cancer

chronic toxicity - Toxic effects produced in test animals exposed for long periods to a chemical

dermal - of, or related to, the skin

EC50 - the concentration which will cause a toxic effect in $50 \%$ of the subjects

formulation - the form in which the pesticide is supplied by the manufacturer for use

half-life - the time required for a chemical to be reduced by natural processes to one half its original amount.

herbicide - a substance used to destroy plants or to slow down their growth

LC50 - the concentration in air or water which will kill $50 \%$ of the subjects

LD50 - the dose which will kill $50 \%$ of the subjects

leach - to dissolve out by the action of water

$\mathbf{m g} / \mathrm{kg}$ - milligrams of the substance per kilogram of body weight. Equals ppm.

mg/ - milligrams of dissolved substance per liter of water. Equals ppm.

microorganisms - living things too small to be seen without a microscope

mutagenicity - ability to cause genetic changes.

non-target - animals or plants other than the ones which the pesticide is intended to kill

persistence - tendency of a pesticide to remain in the envirunment after it is applied

ppb - parts per billion parts

ppm - parts per million parts. Equal to mg/kg. and $\mathrm{mg} / \mathrm{l}$.

residual activity - the remaining amount of activity as a pesticide

sensitizer - a delayed allergic response to a substance; symptoms usually resemble an acute toxic response.

teratogen - a compound having the property of causing birth defects

volatility - the tendency to become a vapor at relatively low temperature

\section{INFORMLATION SOURCES:}

\section{U.S. Governient Agency Publications}

Forest Service, U.S. Department of Agriculture, 1984. Herbicides. Agriculture Handbook No. 633.

Pacific Northwest Region, Forest Service, USDA; Portland, OR. 1988. Final Environmental Impact Statement for Managing Competing and Unwanted Vegetation.

Chapter IV, Environmental Consequences: Human Health Effects Characterization and Management of Risk

Appendix C: Herbicide Use and Efficacy

Appendix D: Quantitative Risk Analysis

Appendix J: Herbicide Review with Wildlifeoriented Effects

U.S. Environmental Protection Agency, Office of Pesticide Programs. Washington, DC, 1986. Pesticide Background Statements. Volume I. EPA Publication Vio. 540)/FS-88-124 
U.S. Envirunmental Protetion Agency. Office of Prevention. Pesticides, and Toxic Substances. Washington D.C. 1993a. Reregistration Eligibility Decision: Glyphosate. EPA Publication No. EPA 738-R-93-014.

U.S. Environmental Protetion Agency, Office of Prevention, Pesticides, and Toxic Substances. Washington D.C. 1993b. Pesticide Tolerances for Glyphosate (Proposed Rule). Federal Régister, Vol. 58, No. 85, May 5, 1993, pp. 26725-26727.

U.S. Environmental Protection Agency, Office of Pesticides and Toxic Substances, Washington, DC. 1986. Guidance for the Reregistration of Pesticide Products Containing Glyphosate as the Active Ingredient. EPA Publication No. 540/RS-R6-156,

Forest Service, USDA, Atlanta, GA. 1989. Final Environmental Impact Statement. Vegetation Management in the Coastal Plan/Piedmont. Management Bulletin R8-MB-23.

Forest Service, USDA, San Francisco, California, 1989.Final Environmental Impact Statement. Vegetation Management for Reforestation.

\section{Monsanto Agricultural Company Publications}

Monsanto Corp. (anon.). 1992. Roundup ${ }^{\circledR}$ Material Safety Data Sheet.

Monsanto Corp. (anon.). 1993a. Accord ${ }^{\infty}$ Material Safety Data Sheet.

Monsanto Corp. (anon.). 1993b. Rodeo ${ }^{\oplus}$ Material Safety Data Sheet.

Monsanto Corp. (anon.). Undated(a). Backgrounder; Roundup ${ }^{()}$Herbicide Ingredients.

Monsanto Corp. (anon.). Undated(b). 1.4-Dioxane Questions and Answers.

\section{OThr.k Sourct.s}

American Conference of Governmental IndustrialHygienists. Inc. 1991. Documentation of the Threshold Limit Values and Biological Exposure Indices. ACGIH. Inc. Cincinnati. OH. pp 512-515.

Austin, A.P., Harris, G.E., and Lucey, W.P. Impact of an Organophosphate Herbicide (Glyphosate) on Periphyton Communities Developed in Experimental Streams. Bull. Environ. Contam. Toxicol. 47: 29-35. 1991.

Brewster, D. W., Warren, J., and Hopkins, W.E. Metabolism of Glyphosate in SpragueDawley Rate: Tissue Distribution. Identification, and Quantitation of Glyphosate-Derived Materials following a Single Oral Dose. Fundamental and Applied Toxicology 17. 1991. pp 43-51.

Chakravarty, P., and Chartapaul, L. Non-target Effect of Herbicides: II. The Influence of Glyphosate on Ectomycorrhizal Symbiosis of Red Pine under Greenhouse and Field Conditions. Pestic. Sci. 0031-613X. 1990.

Dykstra, W., and Ghali,-G. Second Peer Review of Glyphosate. U.S. Environmental Protection Agency Memo. 1991.

Eberbach, P. L.; Douglas, L. A. 1983. Persistence of Glyphosate in a Sandy Loam. Soil Biology and Biochemistry 15 (4). 485-487.

Feng, J.C., and Thompson, D.G. Persistence and Dissipation of Glyphosate in Foliage and Soils of a Canadian Coastal Forest Watershed. In: Proceedings of the Camation Creek Herbicide Workshop. Forestry Canada, FRDA Report ISSN 0835-0752; 063. 1989.

Folmar, Dr. Leroy C., U.S. Department of Commerce. National Oceanic and Atmospheric Administration. Personal Communication to Dr. Robert A. Campbell re: Error in Published Roundup ${ }^{\circledR}$ Concentration in Fish Fillets. 1984. 
Khan. Shahamat U.. and Young. J. Christopher. 1977. N-Nitrosamine Formation in Soil from the Herbicide Glyphosate. Journal of Agricultural and Food Chemistry 25; no. 6: 14301432.

Middendorf. P.J. 1993. Forest worker exposures to glyphosate during directed foliar applications of Roundup herbicide. Rep. Project \#A-8196-000. Ga. Tech. Res. Inst., Ga. Inst. Tech.. Environ. Sci. and Technol. Lab. 71 p.

Newton, Michael, et. al. Fate of Glyphosate in an Oregon. Forest Ecosystem. Journal of Agricultural and Food Chemistry 32 , no. 5 . 1144-1151.

Oppenhuizen, M.E.; Cowell, J.E. Liquid

Chromotographic Determination of Glyphosate and AMPA in Environmental Water: Collaborative Study, J. Assoc. Off. Anal. Chem. Vol. 74, No. 2. 1991.

Preston, C.M. and Trofymow, J.A. Effects of Glyphosate (Roundup ${ }^{\circ}$ ) on Biological Activity ofTwoForest Soils. In: Proceedings of the Camation Creek Herbicide Workshop. Forestry Canada, FRDA Report ISSNN 08350752; 063. 1989.

Sullivan. Thomas P. Influence of Forest Herbicide on Deer Mouse and Oregon Vole Population Dynamics. J. Wildlife Management, Vol 54. No. 4. 1990! pp 566-576.

Wan, M.T.K. The Persistence of Glyphosate and its Metabolite Amino-methyl-phosphonic Acid in Some Coastal British Columbia Streams. Environment. Canada, Environmental Protection Service, Pacific and Yukon Region; Regional Program Report 85-01. 1986.

For more information on glyphosate contact your local Forest Service Office

October 1994 


\section{Toxicity and Risk Cate(;ories}

\section{Estiniates of Health Risks to the Public and to Workers}

from Forest Service Operations

The FEIS predicts levels of human exposure (dose) for project workers and for the public, for both a typical field project and for a large accidental spill. These dose levels are compared to the highest dose level in animal tests that showed no health effect (No,Observed Effects Level). The risk is ranked from "Negligible" to "High" based on the margin between the expected hu- man dose and the highest NOEL_-"no effect" dose. A "High" risk rating means that the highest NOEL dose is not more than ten times larger than predicted human dose under the specified conditions. A "Moderate" risk rating means that the highest NOEL dose is between 10 and 100 times larger than the expected human dose.

\begin{tabular}{|c|c|c|}
\hline \multicolumn{2}{|c|}{ Estimated Health Risks } \\
to Project Workers \\
\hline Worker & General Health & Reproduction \\
\hline $\begin{array}{c}\text { Aerial } \\
\text { Mixer/Laader }\end{array}$ & Low & Low \\
\hline $\begin{array}{c}\text { Backpack } \\
\text { Sprayer }\end{array}$ & Low & Moderate \\
\hline $\begin{array}{c}\text { Right-of-way } \\
\text { Mixer/Loader }\end{array}$ & Negligible & Negligible \\
\hline $\begin{array}{c}\text { Hack-and- } \\
\text { Squirt }\end{array}$ & N/A* & N/A* \\
\hline
\end{tabular}

* Glyphosate was presumed not to be used in hack-and-squirt operations.

\section{Ecotoxological Categories}

\begin{tabular}{|c|c|c|c|c|}
\hline & $\begin{array}{c}\text { Mammalian } \\
\text { (Acute Oral) }\end{array}$ & $\begin{array}{c}\text { Avian } \\
\text { (Acute Oral) }\end{array}$ & $\begin{array}{c}\text { Avian } \\
\text { (Dietary) }\end{array}$ & Acquatic \\
\hline Risk Category & $\mathbf{m g} / \mathrm{kg}$ & $\mathbf{m g} / \mathrm{kg}$ & $\mathbf{m g} / \mathbf{k g}$ & $\mathrm{mg} / \mathrm{kg}$ \\
\hline very highly toxic & $<10$ & $<10$ & $<50$ & $<0.1$ \\
\hline highly toxic & $10-50$ & $10-50$ & $50-500$ & $0.1-1$ \\
\hline moderately toxic & $51-500$ & $51-500$ & $501-1000$ & $>1-10$ \\
\hline slighty toxic & $501-2000$ & $501-2000$ & $1000-5000$ & $>10-100$ \\
\hline practically non toxic & $>2000$ & $>2000$ & $>5000$ & $>100$ \\
\hline
\end{tabular}


Human Hazarids

\begin{tabular}{|c|c|c|c|c|c|c|}
\hline \multirow[b]{2}{*}{ Category } & \multirow[b]{2}{*}{$\begin{array}{c}\text { Signal Word } \\
\text {. }\end{array}$} & \multicolumn{3}{|c|}{ Route of Administration } & \multicolumn{2}{|c|}{ Hazard } \\
\hline & & $\begin{array}{c}\text { Oral } \\
(\mathrm{mg} / \mathrm{kg})\end{array}$ & $\begin{array}{l}\text { Dermal } \\
\text { (mg/kg) }\end{array}$ & $\begin{array}{c}\text { Inhalation } \\
(\mathrm{mg} / \mathrm{l})\end{array}$ & Eye irritation & Skin irritation \\
\hline 1 & $\begin{array}{l}\text { DANGER } \\
\text { Poison }\end{array}$ & $0-50$ & $\begin{array}{l}0-200 \\
:\end{array}$ & $0-0.2$ & $\begin{array}{l}\text { corrosive: comeal } \\
\text { opacity not } \\
\text { reversible within } 7 \\
\text { days }\end{array}$ & comosive \\
\hline II & WARNING & $>50-500$ & $>20(x)-2000$ & $>0.2-2.0$ & $\begin{array}{l}\text { corneal opacity } \\
\text { reversible within } 7 \\
\text { days; irritation } \\
\text { persisting for } 7 \text { days }\end{array}$ & $\begin{array}{l}\text { severe, irritation at } \\
72 \text { hours }\end{array}$ \\
\hline m & CAUTION & $\begin{array}{c}>500-500 \\
0\end{array}$ & $\begin{array}{c}>2000-20 \\
000\end{array}$ & $>2.0-20$ & $\begin{array}{l}\text { no comeal opacity; } \\
\text { irritation reversible } \\
\text { within } 7 \text { days }\end{array}$ & $\begin{array}{l}\text { moderate irritation } \\
\text { at } 72 \text { hours }\end{array}$ \\
\hline IV & none & .5000 & $>20,000$ & $>20$ & no irritation & $\begin{array}{l}\text { mild or slight } \\
\text { irritation at } 72 \text { hours }\end{array}$ \\
\hline
\end{tabular}

\section{Categories of Quality of Health Effects Data}

\begin{tabular}{|l|l|}
\hline Inadequate: & $\begin{array}{l}\text { Inadequate information available for evaluating toxicity. There were too few studies of } \\
\text { sufficient quality to yield useful or reliable information. }\end{array}$ \\
\hline $\begin{array}{l}\text { Marginal- } \\
\text { Inadequate: }\end{array}$ & $\begin{array}{l}\text { Some useful information exists for evaluating toxicity. There were studies of marginal } \\
\text { quality that provided useful information, but studies were inconsistent and some contained } \\
\text { flaws. It is likely that new studies would change estimates. of health effects. }\end{array}$ \\
\hline Marginal: & $\begin{array}{l}\text { Marginal but useful information available for evaluating toxicity. There were studies of } \\
\text { adequate quality, and results did not vary greatly, but more information would increase } \\
\text { reliability. Although new studies may change estimates of health effects. the results are } \\
\text { considered.moderately reliable. }\end{array}$ \\
\hline Adequate: & $\begin{array}{l}\text { Adequate information is available. Studies are of sufficient quality and quantity that } \\
\text { estimates of human health are considered reliable. New studies are unlikely to change } \\
\text { estimates of health effects. }\end{array}$ \\
\hline
\end{tabular}




\section{Triclopyr \\ Herbicide Information Profile}

U. S. DEPARTMENT OF AGRICULTURE

Forest Service, PActific Northwest Region

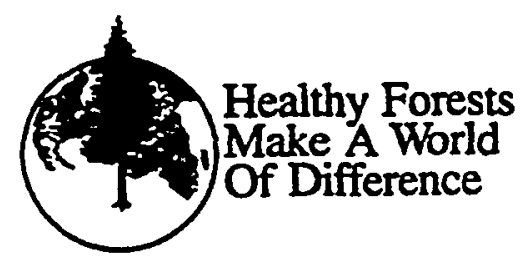

This information profile is produced by the USDA Forest Service, Pacific Northwest Region, for employees, forest workers, and for the public. It provides information on forest and land management uses, environmental and human health effects, and safety precautions for the herbicide triclopyr and its formulations. A list of definitions is included in Section VIIl of the information profile. For general information on herbicide use by the Forest Service, refer to the PNW Region Treatment Methods Profile for Herbicides.

The PNW Region Final Environmental Impact Statement (FEIS) for Managing Competing and Unwanted Vegetation; Forest Service "Herbicide Background Statement: Triclopyr," and product labels and Material Safety Data Sheets are the principal sources of information and conclusions in this profile. Information from other sources is specifically referenced in the profile.

I. BASIC INFORMATION

Common Name: Triclopyr

Chemical Name: [(3,5,6-trichloro-2pyridinyl)oxy]-acetic acid

Product Names: Garlon $3 A^{\circ}$,Garlon $4^{\circ}$, Pathfinder

Registered Use Status: "General Use"

Formuratrons: Formulated triclopyr products contain one or more substances besides triclopyr itself. These substances are called iner ingredients, because they do not kill plants by themselves. The identities of inert ingredients are not usually listed on the label.
DowElanco manufactures all the products discussed in this profile. The manufacturer revealed the identity of all inerts to U.S. Environmental Protection Agency (EPA). The Forest Service has asked the manufacturer to identify inert ingredients for public disclosure in this profile. The manufacturer did not reveal the identity of inert ingredients listed as "surfactants," "emulsifiers," and "aromatic solvent" in these formulations. (DowElanco a, 1992). Where the identity of inerts is not available, this profile may not fully characterize possible hazards to human health and the environment associated with the triclopyr formulation.

\section{Garion $3 A^{\circ}$}

Triclopyr, as the triethylamine salt

$44.4 \%$

Inert ingredients: $55.6 \%$

Water

Surfactants

Ethanol

\section{Garion $4^{*}$}

Triclopyr, as the butoxyethyl ester

Inert ingredients:

Kerosene

Emulsifiers

\section{Pathfinder}

Triclopyr, as the butoxyethyl ester

Inert ingredients: 
The results of formulation testing reported in this profile apply only to Garlon $3 A^{\circ}$, Garlon $4^{\circ}$, and Pathfinder. These products contain only uriclopyr as an active ingredient.

Other formulated products contain both triclopyr and another herbicide. For PNW Region applications, these include Access ${ }^{\bullet}$ Information in this , profile does not address possible effects of these formulated herbicide mixtures.

Restdue AsSay Methods: Gas/liquid chromatography methods are available for residue assay. The manufacturer cites these detection limits for the methods it has developed and shared with other analytical laboratories:
Water

Soil

Plants

(DowElanco d, Undated.)
$1 \mathrm{ppb}$

$10 \mathrm{ppb}$

$50 \mathrm{ppb}$

\section{HERBICIDE Usies}

Registered Forestry, Rangeland, Right-OfWAY UsES: Control of woody plants and broadleaf weeds on right-of-way, non-crop areas, nonirrigation ditch banks, forests, wildlife openings, rangeland and permanent grass pastures.

\section{Operational Detams:}

Target Plants: Triclopyr is used to control woody plants and broadleaf weeds. Triclopyr does not injure grasses at recommended rates.

Mode of Action: Plants respond to triclopyr as if it were a growth hormone; triclopyr interferes with normal plant growth procesșes. It is absorbed by green bark, leaves, roots, and cut stem surfaces and moves throughout the plant. Triclopyr accumulates in the meristem (growth region) of the plant.

Method of Application: Ground or aerial foliage spray, basal bark and stem treatment, cut surface treatment, tree injection.
Use Rates: 0.25 to 9 pounds acid equivalent per acre.

\section{Special Precauttons:}

Always read all of the information on the product label before using any pesticide. Read the label for application restrictions.

Use Restrictions: For triclopyr products discussed in this profile, livestock grazing and hay production are restricted in treated areas. These restrictions are intended to prevent residues of triclopyr in meat and milk that may exceed EPA standards. Time limits and application rates vary among products. Consult the product label for exact restrictions when planning for or applying triclopyr products where grazing occurs.

Timing of Application: For foliar treatment, apply triclopyr during active plant growth. Basal bark and cut surface treatments can be applied at any time of the year. Dormant stem application can only be done when trees and brush are dormant.

Drift Control: Apply triclopyr only when there is little or no hazard of spray drift. Do not allow spray to come in contact with broadleaf crops. Spray only when wind speed is low. Avoid fine spray, which may drift.

\section{ENVIRoNMENTAL EFFECTS/FATE}

Soll:

Residual Soil Activity: Triclopyr is absorbed by plant roots, but it is not considered an effective soil-applied herbicide.

Adsorption: Triclopyr is adsorbed primarily to organic matter particles in soil. The organic matter content is the primary factor in the degree of soil adsorption. Adsorption of triclopyr is generally characterized as "not strong." 
Persistence and Agents of Degradation: Microorganisms degrade triclopyr readily. It degrades more rapidily under warm, moist conditions which favor microbial activity. Persistence varies widely, depending on soil type and climate. Half-lives for triclopyr in western Oregon soils have been reported from 75 to 81 days (Norris, 1987). This study found detectable triclopyr residues in soil $\mathbf{4 7 7}$ days after treatment.

\section{Métabolites/Degradation Products and} Potential Environmental Effects: TCP (3,5,6-Trichloro-2-pyridinol) is the major initial product of degradation. TCP is also a major degradation product of chlorpyrifos, an insecticide. Reported half-lives for TCP range from 8 to 279 days in tests on 15 soil types. TMP is another degradate; it is found less often, and in smaller amounts. Reported halflives for TMP range from 50 to 300 days in three soils. Carbon dioxide has been identified as one final degradation product; other degradates were not identified.

\section{WATER:}

Solubility: Triclopyr solubility was recently reported to be $430-440 \mathrm{ppm}$. The PNW Region FEIS rating would be "Low" solubility. Garlon $4^{\circ}$ and Pathfinder (ester) are not soluble in water, Garlon $3 \mathrm{~A}^{\bullet}$ (amine) is highly soluble.

Potential for Leaching into Ground-Water: The potential for triclopyr leaching increases as soil organic matter decreases, and as climatic conditions reduce soil microbial activity. Triclopyr has some characteristics conducive to leaching behavior. It is not strongly . adsorbed to soil particles, and adsorbed molecules may later detach into water moving through the soil. Triclopyr exceeds the threshold for solubility used by EPA (30 ppm) when evaluating potential for leaching into groundwater (U.S. EPA, 1986).
A trace amount of the metabolite TCP was detected in groundwater at a golf course site. Chlorpyrifos, but not triclopyr, was also detected (Dupuy, 1986). In soil leaching tests, little or no triclopyr has been found below surface layers. The metabolites of triclopyr were less mobile than triclopyr itself. Triclopyr contamination of groundwater has not been reported.

Surface Waters: Sunlight rapidly breaks down triclopyr in water. The half-life of triclopyr in water exposed to sunlight is less than 24 hours. In western Oregon, triclopyr was detected in runoff nine months after application. Researchers concluded that the triclopyr did not come from upslope sprayed areas. The triclopyr had been sprayed directly onto dry streambeds, which became flowing streams during the rainy season, and carried the triclopyr downstream (Norris, 1987).

AIR:

Volatilization: Very low. In monitoring of southern Oregon airsheds, trace amounts of triclopyr were detected in less than ten percent of all samples (Bentson and Norris, 1989).

Potential for By-Products from Burning of Treated Vegetation: DowElanco reports irritating vapors from burning Garlon $3 A^{\oplus}$; nitrogen oxides, hydrogen chloride, and phosgene from Garlon $4^{\oplus}$. Pathfinder produces fumes, smoke, carbon monoxide, and aldehydes, and additionally, the same gases reported for Garlon $4^{\circ}$ (DowElanco c, 1990).

Triclopyr was not detected in monitoring of prescribed burns for air pollution and worker exposure after herbicide treatment. Triclopyr was almost completely consumed when burning treated wood under natural fire conditions. Under smoldering conditions, however, $68 \%$ of triclopyr was recovered intact in smoke (McMahon and Bush, 1990); (Bush, et al., 1987). 
Please refer to Section $X$ for definitions of ecotoxicological categories.

\section{NON-TARGET TOXICITY:}

Soil Microorganisms: Triclopyr did not affect the growth of soil microorganisms up to 500 parts per million (Forest Service, 1984). No studies of effects of these triclopyr formulations have been reported.

Plants: Triclopyr is toxic to many broadleaf plants. Even very small amounts of spray may injure some plants.

Triclopyr residue may be found in edible plant parts; the maximum residue level in berries was teported at $2.4 \mathrm{ppm}$ when harvested six days after treatment (Forest Service, 1984). TCP residues have been detected in root crops following application of chlorpyrifos which also degrades to TCP (Chapman, 1980).

Aquatic Animals: Triclopyr and its formulations have been tested for acute and subacute toxic effects in fish and invertebrates. Triclopyr (acid) is slightly toxic to fish, and from slightly toxic to practically non-toxic to daphnia, an invertebrate. Garlon $3 \mathrm{~A}^{\circ}$ was consistently less toxic to aquatic animals than triclopyr. Garlon $4^{\circ}$ was consistently more toxic; however Garlon $4^{\circ}$ rapidly changes to triclopyr acid in surface waters.

Acute toxic level:

\begin{tabular}{|c|c|c|c|}
\hline pecies & Triclopyr & Garlon 3A & Garlon $4^{\circ}$ \\
\hline & LC50 & & LC50 \\
\hline trout & $\begin{array}{l}117 \mathrm{ppm}^{\mathrm{d}} \\
8.4 \mathrm{ppm}^{\mathrm{b}}\end{array}$ & $420 \mathrm{ppm}^{6}$ & $2.7 \mathrm{ppm}^{6}$ \\
\hline $\begin{array}{l}\text { salmon } \\
\text { bluegill }\end{array}$ & $\begin{array}{l}7.8 \mathrm{ppm}^{\mathrm{b}} \\
148 \mathrm{ppm}^{\mathrm{d}}\end{array}$ & 275 ppm? & $1.4 \mathrm{ppm}^{\mathrm{b}}$ \\
\hline 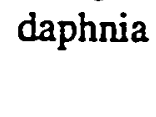 & $133 \mathrm{ppm}^{\mathrm{d}}$ & & $\begin{array}{c}1.2 \mathrm{ppm}^{\mathrm{c}} \\
\text { (EC50) }\end{array}$ \\
\hline
\end{tabular}

(b: Wan, 1987; c: Servizi, 1987; d: DowElanco $\mathrm{d}$, undated)
Tests of Garlon $3 A^{\circ}$ reproductive/developmental effects in minnows and Daphnia showed no effects from long-term exposure (DowElanco d).

Garlon $4^{\circ}$ has been observed to cause behavioral (neurological) changes in salmon fry that may affect survivability when exposed to $1 / 4$ to $1 / 2$ of lethal levels for up to 96 hours. Triclopyr acid accumulated in fish tissues during the exposure. Reversibility was not studied; but associated behavioral effects were reversible in uncontaminated water (Morgan, 1991); (Johansen, 1990). Physiological stress was not observed during other tests of longterm exposure of salmon fry to Garlon $3 A^{\circ}$ and Garlon $4^{\circ}$ (Janz, 1990).

Terrestrial Animals: Triclopyr is slightly toxic to mammals and to birds. Triclopyr is practically non-toxic to bees. Acute toxic level of triclopyr:

\begin{tabular}{lc} 
Species & LD50 \\
\hline mammals & $310-713 \mathrm{mg} / \mathrm{kg}$ \\
ducks & $1,698 \mathrm{mg} / \mathrm{kg}$
\end{tabular}

48-hour contact toxicity to bees $=>60$ micrograms/bee.

In eight day dietary studies in birds, the LC50 for triclopyr ranged from $2,935 \mathrm{ppm}$ to greater than $5,000 \mathrm{ppm}$. The formulations were less toxic than triclopyr itself to birds in both acute toxic and dietary studies.

No tests of formulations for acute toxicity to wildlife mammals have been reported. Triclopyr and its formulations have not been tested for chronic effects in wildlife mammals.

In mammals, most triclopyr is excreted, unchanged, in the urine. Triclopyr has been observed to concentrate slightly in ovaries of laboratory animals given repeated doses. No accumulation was observed in other tissues. The authors concluded that triclopyr and its 
metabolites are likely to have a low potential to accumulate upon repeated exposure (Timchalk et al., 1990).

\section{Threatened and Endangered Species:}

Triclopyr may be a hazard to endangered plant species if it is used in areas where they live. EPA has not determined whether triclopyr could be a hazard to endangered animal species.

\section{Health EfFects Testing}

The data are results of laboratory animal studies. These data have been evaluated by the Forest Service and are used to make inferences relative to human health.

For triclopyr and DowElanco formulations containing triclopyr as the only active ingredient (Garlon $3 A^{\oplus}$, Garlon $4^{\circ}$, and Pathfinder 9 , findings are from studies conducted by the manufacturer. These studies have been presented to EPA to support product registration, but may not be available to the public.

Formulation tests are noted for each category of acute toxicity. Numerical results are only noted for tests of formulations which showed significantly greater toxicity than triclopyr alone.

\section{ACUTE ToXicITY:}

Acute Oral Toxicity: In tests in rats, the acute oral median lethal dose was 630 to 729 $\mathrm{mg} / \mathrm{kg}$. Slightly Toxic (Caregory III).

All formulations listed in this profile have been tested and found to be less toxic than triclopyr itself.

Acute Dermal Toxicity: Median Lethal Dose in rabbits:

Triclopyr $>2,000 \mathrm{mg} / \mathrm{kg}$

Slightly Toxic (Category III).

All listed formulations have been tested and found to be no more toxic than triclopyr itself.

Primary Skin Irritation: tests in rabbits:

\section{Triclopyr}

Slight to moderate irritant (Toxicity Category III to IV).

All formulations may cause skin irritation from prolonged or repeated exposure. Garlon $3 A^{\circ}$ may cause a burn. Garlon $4^{\circ}$ and Pathfinderoare considered potential skin sensitizers (DowElanco c, 1990 ).

Primary Eye Irritation: tests in rabbits:

Triclopyr

Slight eye irritant (Category III).

Garlon $4^{\circ}$ and Pathfinder ${ }^{\circ}$ are slightly irritating to eyes. Undiluted Garlon $3 A^{\star}$ is severely irritating and injurious to eyes (Category I).

Acute Inhalation: In tests in rats, exposure to $5.34 \mathrm{ppm}$ of triclopyr for one hour caused no adverse effects (Toxicity Category III).

Garlon $4^{\circ}$ caused nasal irritation but no deaths in rats exposed to $0.82 \mathrm{mg} / \mathrm{l}$ concentration for four hours.

\section{Chronic Toxictry:}

These data are also based on tests in laboratory animals. EPA requires these tests only for the active ingredient triclopyr. No tests of formulations for chronic toxicity have been reported. Please refer to Section $X$ for an explanation of how NOEL (No Observable Effects Level) is calculated.

The Pacific Northwest Region FEIS risk assessment evaluated the quality of the testing that had been done on triclopyr up to 1988 . Quality considerations for individual studies included: ranges of doses and species that were tested; length of test; identification of the most sensitive effect. Additionally, the degree of quantitative agreement among all tests for an effect was considered. 
Please refer to Section $X$ for an explanation of qualitative ratings in this section.

\section{SysteanIC Toxictry:}

NOEL for triclopyr: $2.5 \mathrm{mg} / \mathrm{kg} /$ day (dog tests).

Toxic effects have been observed on liver and kidney functions.

The PNW Region FEIS rated the quality of testing as Marginal-Inadequate.

\section{Carcinogenictty/Mutagenicity:}

Laboratory tests in mice and rats fed up to $30 \mathrm{mg} /$ $\mathrm{kg}$ per day for 2 years did not show any evidence of carcinogenicity.

Triclopyr was negative in several laboratory tests for mutagenicity (the ability to cause genetic damage), but was weakly positive in one test in rats. A more recent study, accepted by EPA, was negative for this same effect (DowElanco e, 1992).

The PNW Region FEIS rated the quality of testing as Marginally Adequate for these effects.

\section{REPRODUCTION/DEVELOPMENTAL:}

Reproduction: A three-generation reproduction study in rats did not show any adverse effects on fertility or reproduction at doses up to $30 \mathrm{mg} / \mathrm{kg}$ per day.

Developmental: Laboratory studies with triclopyr in pregnant rats (at dose levels up to $200 \mathrm{mg} / \mathrm{kg}$ per day) and rabbits (at dose levels up to $100 \mathrm{mg} / \mathrm{kg}$ per day) indicated no evidence of teratology (birth defects). In pregnant rats at the $200 \mathrm{mg} / \mathrm{kg}$ per day dose level, there were signs of mild toxicity to the fetus.

The PNW Region FEIS evaluated the testing as Marginally Adequate for these effects.

\section{Othes Possible Hralth Effocts}

There was insufficient information available to evaluate the potential for effect to the nervous or immune systems. Toxicity to nervous system components was not observed in DowElanco studies of systemic health effects (DowElanco e, 1992). No studies of triclopyr formulation effects were reported.

The metabolite TCP was not shown to be neurotoxic, carcinogenic, mutagenic, or to cause birth defects in studies of chlorpyrifos reviewed by EPA (EPA, 1984).

\section{HUMAN HEALTH EFFECTS}

Forest Service Evaluation of Human Health Rusks

The Pacific Northwest Region evaluated a range of triclopyr health effects data, including laboratory studies cited in Section V. Both quantitative (numerical) estimates of toxicity, and the quality of data used to make, numerical estimates were evaluated.

The FEIS Quantitative Risk Assessment predicts the amount of human exposure-both to project workers and to the public-from typical forestry operations, and also from a large accidental spill. The Risk Assessment used this information to assess health risks from typical uses. These risks were compared to EPA standards of acceptable risk for human health effects. The FEIS risk assessment identified as "Moderate" or "High" any predicted risks from Forest Service operations that were greater than EPA standards. Specific mitigation measures were designed to reduce human exposure from these operations; they are mandatory for every applicable project on $\mathrm{Na}$ tional Forest lands.

The complete set of risk ratings is displayed in Section $\mathrm{X}$.

The quality of the existing data affects the reli- 
ability of these risk ratings. The FEIS judged the overall quality of available data on triclopyr toxicity to be "Marginal to Inadequate." There were some studies of marginal quality that provided useful information, but studies were inconsistent and some contained flaws. It is likely that new studies would change estimates of health effects. Very cautious assumptions were made in characterizing risk.

\section{Potential for Health Effects to the Public}

Forest visitors and nearby residents could be exposed to herbicide drift, to vegetation with herbicide residues, and to accidental spraying. They also could eat food or drink water containing herbicide residues. No studies of public exposure were available; public doses were estimated based on the behavior of the herbicide in the environment. The "Routine Application" situation estimates maximum possible public exposure under normal operating conditions. The "Large Spill" situation models the highest doses that could be reasonably be expected to occur. Typical public exposures and risks would be much lower than either situation.

\section{Mitigating Measures to Reduce Triclopyr Risks to Public}

"Moderate" risk of general health effects, and of reproductive health effects for people who receive multiple exposures from a large (400 acre) aerial application project. "Low" risk for smaller ( 40 acre) aerial projects, and for all ground-based applications:

Consider potential for public expósure when designing contact procedures, posting and signing needs in the Herbicide Application Plan.

"High" risk of general health effects, and "High" risk of reproductive effects if exposed to concentrated triclopyr from a large spill:

Prevent all public contact with accidental spills (emergency spill notification system, restrict public access to spill site).

\section{Probabiluty of a Worker Receiving a Dose Which Afrects General Health or REPRODUCTION}

Worker exposure and dose are estimated for typical forestry applications. Studies are available that measure actual worker doses of herbicide for some typical forestry applications. Worker doses do not account for any reduction in exposure from following safety precautions or mitigating measures (such as wearing protective clothing).

\section{Mitigating Measures to Reduce Identified TrICLOPYR RISKS TO WORKERS}

The probability of worker exposure to a toxic concentration for either general health or reproductive effects was rated "Low" or "Negligible" for all application methods except for backpack sprayers, for which risk was rated "Moderate."

In the PNW Region FEIS, Mitigating Measure 13 requires workers applying any herbicide to wear protective clothing. Mitigating Measure 23 requires worker exposure monitoring for all herbicide application projects.

The 1992 Amendment to the PNW Record Of Decision requires workers to review this Information Profile before agreeing to apply triclopyr herbicides. The worker may request reassignment without penalty. Additional personal protective equipment must be available at the worksite for workers who want to reduce their exposure to the herbicide.

\section{ACUte Toxicity (Polsoning)}

Reported Effects: Cases of eye and skin irritation have been reported in workers exposed to triclopyr formulations. Absorption and excretion of triclopyr was measured in human volunteers. Both oral and skin exposures were studied. Orally administered triclopyr was rapidly absorbed and rapidly excreted as unchanged triclopyr in the urine. Triclopyr was slowly and poorly absorbed through human skin. The authors concluded that the potential for triclopyr to bioaccumulate, and the potential to be ab- 
sorbed through skin to acutely toxic levels are both low. Medical examinations of the volunteers after each test found no treatment-related health effects (Carmichael et ạ., 1989).

Triclopyr was reported to have been detected in the urine of a Forest Service employee who was mixing herbicides. No health effects were reported (Hoglund, 1985).

\section{Long Term Human Health Effects:}

Reported Effects: There are no reported cases of long term health effects in humans due to triclopyr or its formulations.

\section{Potential for Adverse Health Effects from} Inert Ingredients Contained in the Formulated Product: The manufacturer has revealed the identity of some inert chemicals in triclopyr formulations;' other inerts are not identified. Specific toxicity information is not available for every inert ingredient. Kerosene, an ingredient of Garlon $4^{\circ}$, was categorized by EPA to have suggestion of toxic effects. All other triclopyr inert ingredients were categorized as either: low priority for health effects testing based on absence of data or a chemical structure suspected to cause toxic effects (List 3 ); or generally recognized to be safe (List 4).

Gàrlon $3 A^{\oplus}$ contains one percent ethanol (ethyl alcohol). Pure ethanol causes adverse health effects if swallowed, including neurologic effects, liver effects, toxic effects, birth defects, and reduced male fertility. Information is inadequate to determine potential cancercausing and mutagenic effects. Exposure to ethanol from triclopyr would be very low in typical forestry operations.

Garlon $4^{\circ}$ contains kerosene. Kerosene may cause lung damage or'death if inhaled in liquid form. It may affect the central nervous system (DowElanco c, 1990). Kerosene is a skin irritant. It did not damage DNA or chrómosomes in tests, or cause cancer in laboratory animals. Kerosene does contain small amounts of other petroleum compounds that are known to cause cancer. The PNW Region FEIS did not find adequate information to evaluate the risk of health effects from kerosene.in

Garlon $4^{\circ}$ in forestry operations.

Pathfinder contains a petroleum-like solvent. This solvent may cause lung damage or death if inhaled in liquid form. Excessive exposure may cause neurologic, blood, and lung effects (DowElanco c, 1990).

Health Effects Associated with Contaminants: No known contaminants. The potential to form a dioxin-related compound during the manufacture or burning of triclopyr has been speculated. DowElanco reports that this compound has not been detected in triclopyr products, and is not produced upon heating of triclopyr (Rohrer, 1984). A consortium of state extension services found there is no possibility of dioxin-family contaminants occurring in triclopyr (Extoxnet, undated).

\section{Health Effects Associated with Other} Formulations: Some formulations contain triclopyr mixed with the herbicides $2,4-D$ or picloram. Information Profiles for 2,4-D or Picloram describe the properties and potential effects of the other herbicide ingredients. None of these profiles fully describe the potential for health or environmental effects from these formulations containing multiple herbicides. Additional information on properties and potential effects of these formulations will be prepared before they are used in the PNW Region.

\section{Societal Perceptions:}

Public opinion about herbicide use in general ranges from a perception that herbicides are completely safe, to a perception that they are very hazardous. A full range of opinion is available in the FEIS. The PNW Region has contracted to produce a bibliography of recent anecdotal and scientific accounts, and an analysis of reported worker health effects. This information profile will be updated to reflect the results of these 


\section{Safety Precautions}

Signal Word and DeFinition:

Pathfinder- CAUTION: Harmful if swallowed, inhaled or absorbed through skin. Causes eye irritation.

Garlon $4^{\circ}$. CAUTION - Harmful if swallowed, inhaled or absorbed through skin.

Garlon $3 A^{\circ}$ - DANGER - Corrosive. Causes irreversible eye damage. Harmful if swallowed, inhaled, or absorbed through the skin. Prolonged or frequently repeated skin contact with herbicide concentrate may cause an allergic skin reaction in some individuals.

Protective Precautions for Workers: Avoid contact with eyes, skin, or clothing. Avoid contamination of food. Avoid breathing mists or vapors. Wash thoroughly after handling. Remove and wash contaminated clothing before reuse. For Garlon $3 A^{\oplus}$, wear goggles, face shield, or safety glasses, and rubber gloves when handling.

Medical Treatment Procedures (Antmotes): There is no specific antidote known; treat the symptoms. If swallowed, get medical attention. For exposure to skin, wash with plenty of soap and water. Get medical attention if irritation persists.

For eye exposure to Garlon $3 A^{\circ}$, flush with plenty of water for at least 15 minutes. Get medical attention.

For Garlon $3 A^{\oplus}$, if swallowed, promptly drink a large quantity of milk, egg whites, gelatin solution, or if these are not available, drink large quantities of water. Avoid alcohol. Call a physician. Do not induce vomiting.

In case of emergency, call your local poison control center for advice.
Handerng, Storage, and Disposal: Avoid contact with eyes, skin or clothing. Do not ship or store with food, animal feeds, drugs or clothing. Triclopyr formulations are combustible. Do not use or store near heat or open flame. Do not cut or weld container. Triclopyr is stable for at least two years under normal storage conditions. Do not contaminate water by disposal. Dispose of this pesticide according to federal, state, or local procedures.

Emierreancy (Spitl) Hazards and Procedures: Dike large spills. Keep the spill out of streams and water supplies. Absorb small spills with kitty litter or other inert material. Bury material from small spills of Garlon $3 A^{\circ}$ in non-crop area away from water supplies. For large spills, contact the manufacturer for instructions. Observe all local, state, and federal rules for disposal. In case of a large spill, call CHEMTREC at 1-800-424-9300 for advice.

\section{Definimons}

acute toxicity - the amount of a substance, as a single dose, to cause poisoning in a test animal

adsorption - the process of attaching to a surface

basal treatment - applied to the stem of a plant just above the soil

bioaccumulate - the uptake of a chemical by an organism from its environment.

broadcast application - applied over an entire area

carcinogenicity - ability to cause cancer

chronic toxicity - toxic effect produced in test animals exposed for long periods to a chemical

dermal - of, or related to, the skin

EC50 - the concentration in air or water which will cause a toxic effect in $50 \%$ of the subjects

formulation - the form in which the pesticide is supplied by the manufacturer for use

half-life - the time required for a chemical to be 
reduced by natural processes to one half its original amount

herbicide - a substance used to destroy plants or to slow down their growth

LC50 - the concentration in air or water which will kill $50 \%$ of the subjects

LD50 - the dosé which will kill $50 \%$ of the subjects.

leach - to dissolve out by the action of water

$\mathrm{mg} / \mathrm{kg}$ - milligrams of the substance per kilogram of weight Equals ppm.

mg/ - milligrams of dissolved substance per liter of water. Equals ppm.

microorganisms - living things too small to be seen without a microscope

mutagenicity - ability to cause genetic changes

non-target - animals or plants other than the ones which the pesticide is intended to kill

persistence - tendency of a pesticide to remain in the environment after it is applied

ppb - parts per billion parts

ppm - parts per million parts. Equal to $\mathrm{mg} / \mathrm{kg}$, and $\mathrm{mg} / \mathrm{l}$

residual activity - the remaining amount of activity as a pesticide

sensitizer - a delayed allergic response to a substance; symptoms usually resemble an acute toxic response

teratogen - a compound having the property of causing birth defects

volatility - the tendency to become a vapor at relatively low temperature

\section{INFORMATION SOURCES:}

Pacific Northwest Region, Forest Service, U.S. Department of Agriculture. 1988. Final Environmental Impact Statement for Manag- ing Competing and Unwanted Vegetation.

Chapter IV, Environmental Consequences: Human Health Effects, Characterization and Management of Risk

Appendix C: Herbicide Use and Efficacy

Appendix D: Quantitative Risk Analysis

Appendix H: Qualitative Risk Analysis

Appendix J: Herbicide Review with Wildlifeoriented Effects

Forest Service, U.S. Department of Agriculture. 1984. Pesticide Background Statements. Volume 1. Herbicides. Agriculture Handbook No. 663.

U.S. Environmental Protection Agency, Office of Ground-Water Protection. 1986. Pesticides in Ground Water: Background Document, p. 42.

U.S. Environmental Protection Agency, Office of Pesticide Programs. 1984. Guidance for the Reregistration of Pesticide Products Containing Chlorpyrifos as the Active Ingredient, p. 8.

DowElanco Publications:

a. Ingredient Lists for Products Containing Triclopyr, 1992.

b. Product Labels: Garlon 3A; Garlon 4", Pathfinder

c. Material Safety Data Sheets: Garlon 3A\%, Garlon 4, Pathfinder, 1990.

d. Triclopyr Technical Information Guide. Undated.

c. Personal communication, V. CarrithersDowElanco Technical Representative, 1992.

Bentson, K., and L. Norris. 1989. Baseline Concenitration measurements of herbicides in the - Air of Southwest Oregon. FIR Report Vol. 10, \#4: pp. 7-8. 
Bush, P., D. Neary, C. McMahon, and J. Taylor. 1987. Suitability of Hardwoods treated with Phenoxy and Pyridine Herbicides for Use as Firewood. Arch. Environ. Contam. Toxicol 16: pp. 333-341.

Carmichael, N., R. Nolan, J. Perkins, R. Davies, and S. Warrington. 1989. Oral and Dermal Pharmacokinetics of Triclopyr in Human Volunteers. Human Toxicology 8: pp. 431-437.

Chapman, R. 1980. Persistence of Chlorpyrifos in a Mineral and An Organic Soil. J. Environ. Sci. Health, B15(1): pp. 39-46.

Dupuy, Aubry E. Jr. 1986. Memo: Analytical Results for August Sampling of Cape Cod Golf Course Groundwater Monitoring Study. U.S. Environmental Protection Agency Environmental Chemistry Laboratory.

Exténsion Toxicology Network, undated. Triclopyr Pesticide Information Profile. Oregon State University Extoxnet.

Hoglund, G. 1985. Urinalysis Test, Part III. NCAP News, Spring: p. 20.

Janz, D, A. Farrell, J. Morgan, and G. Vigers. 1991. Acute Physiological Stress Responses of Juvenile Coho Salmon to Sublethal Concentrations of Garlon $4^{\circ}$, Garlon $3 A^{\circ}$; and Vision Herbicides. Environmental Toxicology and Chemistry 10: pp. 81-90.

Johansen, J., and G. Geen. 1990. Sublethal and Acute Toxicity of the Ethylene Glycol Butyl Ether Ester Formulation of Triclopyr to Juvenile Coho Salmon. Arch. Environ. Contam. Toxicol 19: pp. 610-616.

McMahon, C. K., and P. B. Bush. 1990. Evaluation of Worker Exposure to Herbicide Residues in the Smoke from Prescribed Fires in the South. U.S.D.A, Forest Service NAPIAP Project SO-30.

Morgan, J., G. Vigers, A. Farrell, D, Janz, and J. Manville. 1991. Acute Avoidance Reactions and Behavioral Responses of Juvenile Rainbow Trout to Garlon 4, Garlon 3A; and Vision Herbicides. Environmental Toxicology and Chemistry, Vol. 10: pp. 73-79.

Norris, L. C, M. L. Montgomery, and L. E. Warren. 1987. Triclopyr Persistence in Western Oregon Hill Pastures. Bull. Environ. Contam. Toxicol 39: pp. 134-141.

Rohrer, T. 1984. Letter to D. Hebert. Environmental Services Division, Michigan Department of Natural Resources.

Servizi, J., R. Gordon, and D. Martens. 1987. Acute Toxicity of Garlon $4^{\circ}$ and Roundup Herbicides to Salmon, Daphnia, and Trout. Bull. Environ. Contam. Toxicol 39: pp. 15-22.

Timchalk, C, M. Dryzga, and P. Kastl. 1990. Pharmacokinetics and metabolism of triclopyr in Fischer 344 rats. Toxicology 62: pp. 7187.

Wan, M., D. Moul, and R. Watts. 1987. Acute Toxicity to Juvenile Pacific Salmonids of Garlon 3A', Garlon 4', Triclopyr Ester, and Their Transformation Products: 3,5,6Trichloro-2-pyridinol and 2-Methoxy-3,5,6trichloropyridine. Bull. Environ. Contam. Toxicol 39: pp. 721-728.

\section{For more information on triclopyr, contact your local Forest Service office.}

October 1992

This Triclopyr Information Profile is based on the "Triclopyr Pesticide Fact Sheet" developed by Information Ventures, Inc., under USDA Forest Service Contract Number 53-3187-104. 


\section{Toxicity and Risk Categories}

Estimates of Health Risks to the public aNd to WORKERs from Forest SERvice Operations

The FEIS predicts levels of human exposure (dose) for project workers and for the public, for both a typical field project and for a large accidental spill. These dose levels are compared to the highest dose level in animal tests that showed no health effect (No Observed Effects Level). The risk is ranked from "Negligible" to "High" based on the margin between the expected human dose and the highest NOEL-"no effect" dose. A "High" risk rating means that the highest NOEL dose is not more than ten times larger than predicted human dose under the specified conditions.

A "Moderate" risk rating means that the highest NOEL dose is between 10 and 100 times larger than the expected human dose.

\begin{tabular}{|c|c|c|}
\hline \multicolumn{2}{|c|}{$\begin{array}{c}\text { Estimated } \\
\text { To }\end{array}$} & \multicolumn{1}{c|}{ Health } \\
The Public \\
\hline Situation & $\begin{array}{c}\text { General } \\
\text { Health }\end{array}$ & Reproduction \\
\hline $\begin{array}{c}\text { Routine } \\
\text { Large Aerial } \\
\text { Application }\end{array}$ & Moderate & Moderate \\
\hline $\begin{array}{c}\text { Routine } \\
\text { Application } \\
\text { Other }\end{array}$ & Low & Low \\
\hline Large Spill & High & High \\
\hline
\end{tabular}

\section{Estimated Health Risks To Project Workers}

\begin{tabular}{|c|c|c|}
\hline Situation & $\begin{array}{c}\text { General } \\
\text { Health }\end{array}$ & Reproduction \\
\hline $\begin{array}{c}\text { Aerial } \\
\text { Mixer/Loader }\end{array}$ & Low & Low \\
\hline $\begin{array}{c}\text { Backpack } \\
\text { Sprayer }\end{array}$ & Moderate & Moderate \\
\hline $\begin{array}{c}\text { Right-of-way } \\
\text { Mixer/Loader }\end{array}$ & Negligible & Negligible \\
\hline $\begin{array}{c}\text { Hack-and- } \\
\text { Squirt }\end{array}$ & Low & Low \\
\hline
\end{tabular}

Ecotoxological Categories

\begin{tabular}{|c|c|}
\hline \multicolumn{2}{|c|}{ Mammalian (Acute Oral): } \\
\hline$m g / k g$ & Risk Category \\
\hline$<10$ & very highly toxic \\
\hline $10-50$ & highly toxic \\
\hline $51-500$ & moderately toxic \\
\hline $501-2000$ & slightly toxic \\
\hline$>2000$ & practically non toxic \\
\hline
\end{tabular}

\begin{tabular}{|c|c|}
\hline \multicolumn{2}{|c|}{ Avian (Acute Oral): } \\
\hline$m g / k g$ & Risk Category \\
\hline$<10$ & very highly toxic \\
\hline $10-50$ & highly toxic \\
\hline $51-500$ & moderately toxic \\
\hline $501-2000$ & slightly toxic \\
\hline$>2000$ & practically non toxic \\
\hline
\end{tabular}

\begin{tabular}{|c|c|}
\hline \multicolumn{2}{|c|}{ Avian (Dietary): } \\
\hline$p p m$ & Risk Category \\
\hline$<50$ & very highly toxic \\
\hline $50-500$ & highly toxic \\
\hline $501-1000$ & moderately toxic \\
\hline $1001-5000$ & slightly toxic \\
\hline$>5000$ & practically non toxic \\
\hline
\end{tabular}

\begin{tabular}{|c|c|}
\hline \multicolumn{2}{|c|}{ Aquatic Organisms: } \\
\hline$p p m$ & Risk Category \\
\hline$<0.1$ & very highly toxic \\
\hline $0.1-1$ & highly toxic \\
\hline$>1-10$ & moderately toxic \\
\hline$>10-100$ & slightly toxic \\
\hline$>100$ & practically non toxic \\
\hline
\end{tabular}




\section{Table of Categories of TOXICITY}

\begin{tabular}{|c|c|c|c|c|}
\hline & \multicolumn{4}{|c|}{ Human Hazards } \\
\hline Risk Category & Signal Word & $\begin{array}{c}\text { Oral } \\
(\mathbf{m g} / \mathbf{k g})\end{array}$ & Dermal (mg/kg) & $\begin{array}{c}\text { Inhalation } \\
(\mathbf{m g} / \mathrm{kg})\end{array}$ \\
\hline I & DANGER--Poison & $0-50$ & $0-200$ & $0-0.2$ \\
\hline II & WARNING & $>50-500$ & $>200-2000$ & $>0.2-2.0$ \\
\hline III & CAUTION & $>500-5000$ & $>2000-20,000$ & $>2.0-20$ \\
\hline IV & NONE & $>5000$ & $>20,000$ & $>20$ \\
\hline
\end{tabular}

\begin{tabular}{|c|c|c|}
\cline { 2 - 3 } \multicolumn{1}{c|}{} & \multicolumn{2}{c|}{ Hazard } \\
\hline Category & Eye Irritation & Skin Irritation \\
\hline I & $\begin{array}{c}\text { Corrosive: corneal opacity not reversible within } 7 \\
\text { days }\end{array}$ & corrosive \\
\hline II & $\begin{array}{c}\text { corneal opacity reversible within 7 days; irritation } \\
\text { persisting for 7 days }\end{array}$ & $\begin{array}{c}\text { severe irritation } \\
\text { at 72 hours }\end{array}$ \\
\hline III & $\begin{array}{c}\text { no comeal opacity; irritation reversible } \\
\text { within 7 days }\end{array}$ & $\begin{array}{c}\text { moderate irritation } \\
\text { at 72 hours }\end{array}$ \\
\hline IV & no irritation & $\begin{array}{c}\text { mild or slight irritation } \\
\text { at 72 hours }\end{array}$ \\
\hline
\end{tabular}

\section{Categories of Quality of Health Effects Data}

Inadequate:

MarginalInadequate:

Marginal:

Adequate:
Inadequate information available for evaluating toxicity. There were too few studies of sufficient quality to yield useful or reliable information.

Some useful information exists for evaluating toxicity. There were studies of marginal quality that provided useful information, but studies were inconsistent and some contained flaws. It is likely that new studies would change estimates of health effects.

Marginal but useful information available for evaluating toxicity. There were studies of adequate quality, and results did not vary greatly, but more information would increase reliability. Although new studies may change estimates of health effects, the results are considered moderately reliable.

Adequate information is available. Studies are of sufficient quality and quantity that estimates of human health are considered reliable. New studies are unlikely to change estimates of health effects. 


\section{Picloram}

Herbicide Information Profilé

U. S. DEPARTMENT OF AGRICULTURE

Forest SERVICE, PACIFIC NoRThWEST Region

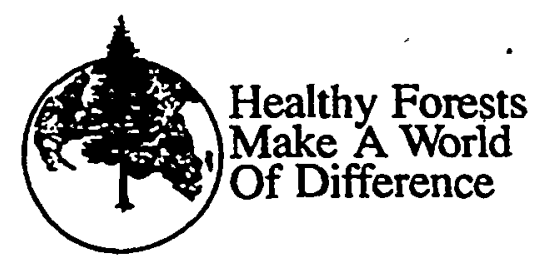

This information profile is produced by the USDA Forest Service, Pacific Northwest Region, for employees, forest workers, and for the public. It provides information on forest and land management uses, environmental and human health effects, and safety precautions for the herbicide Picloram and its formulations. A list of definitions is included in Section VIII of the information profile. For general information on herbicide use by the Forest Service, refer to the PNW Region Treatment Methods Profile for Herbicides.

\section{BASIC INFORMATION}

\section{Common NAME: Picloram}

Chemical Name: 4-amino-3,5,6trichloropicolinic acid

\section{Product Names: Tordon@}

Registered Use Status: All formulations that may be broadcast on soil or foliage are classified as "Restricted Use" pesticides. Sale and use of these picloram formulations are limited to licensed pesticide applicators or employees under their supervision, and only for uses covered by the applicator's certification. This is due to picloram's potential to contaminate groundwater, and its ability to damage nontarget plants, including important food crops (US-EPA, 1988a.)

The formulations discussed in this profile are both Restricted Use Pesticides.

Formulations: Commercial picloram products generally contain one or more inert ingredients. An inert ingredient is anything added to the product other than the herbicide. The names of inert ingredients are not usually listed on the label.

\section{Tordon $(\mathrm{K}$ and Tordon® 22K}

(Manufactured by DowElanco)

Picloram, as the potassium salt Inert ingredients:

$75.6 \%$

Water

Dispersing agents

The manufacturer has not revealed the identity of the inert ingredients other than water in these formulations (DowElanco a, 1992). Where the identity of inerts is not available, this profile cannot fully characterize possible hazards to human health and the environment associated with these compounds.

The manufacturer has revealed all inerts to EPA (U.S. Environmental Protection Agency). No inert ingredient in Tordon $\otimes \mathrm{K}$ or $22 \mathrm{~K}$ formulations was categorized by EPA to have evidence or suggestion of toxic effects. The inert ingredients were categorized as either: low priority for health effects testing based on absence of data or chemical structure that would indicate toxic effects (List 3 ); or generally recognized to be safe (List 4).

The results of formulation testing reported in this profile apply only to Tordon $\circledast \mathrm{K}$ and Tordon $\circledast$ $22 \mathrm{~K}$. They contain only picloram as an active. ingredient.

Other herbicide formulations contain both picloram and another herbicide. For Forest Service applications, these include: Access ${ }^{\circ}$, Pathway ${ }^{\circledR}$, Tordon® RTU, and Tordon $® 101$. Information in this profile does not address possible effects of these formulated herbicide mixtures. 
Resmue Assay Methods: Gas/liquid chromatography and reverse phase high performance liquid chromatography methods are available for residue assay. Detection limits in tests submitted to EPA are:

$\begin{array}{ccc}\text { Water } & 0.1 & \mathrm{ppb} \\ \text { Soil } & 5.0 & \mathrm{ppb} \\ \text { Plants } & 50 & \mathrm{ppb}\end{array}$

(DowElanco Publication d. Undated.)

EPA cites a validated detection limit for picloram in water of $0.14 \mathrm{ppb}$ (EPA, 1988c).

A 1982 study found that among 10 contract laboratories, water samples with $50 \mathrm{ppb}$ picloram added were frequently underestimated, and sometimes not detected (Norris, 1982).

\section{HeRBICIDE USES}

Registered Forestry, Rangeland, Right-ofWAY USES: Tordon $\AA \mathrm{K}$ is used to prevent regrowth of woody plants in rights-of-way, such as along roads and power lines. In forestry, Tordon ${ }^{\circledR}$ $\mathrm{K}$ is used to control unwanted woody plants and to prepare sites for planting trees. On rangelands, Tordon( ${ }^{8} 22 \mathrm{~K}$ is used to control noxious weeds and woody plants. It is also used to control plants on non-crop industrial/facility sites.

\section{Operational Details:}

Target Plants: Picloram is used to control broadleaf plants, brush, conifers and broadleaf trees. Most grasses are resistant to picloram.

Mode of Action: Picloram is absorbed through plant roots, leaves and bark. It moves both up and down within the plant, and accumulates in new growth. It acts by interfering with the plant's ability to make proteins and nucleic acids. Picloram is metabolized or broken down by plants into carbon dioxide, oxalic acid, 4-amino-2,3,5-trichloropyridine and 4-amino-3,5-dichloro-6-hydroxypicolinic acid.
Method of Application: Broadcast or spot treatment as foliar (leaf) or soil spray; by air as broadcast spray.

UsE RATES: The amount to be applied depends on the type of plant to be killed, and the formulation of picloram used. The formulations containing only picloram as the active ingredient use the potassium salt.

Picloram, potassium salt: 1.0 to $2.0 \mathrm{lb}$. active ingredient/acre.

\section{Special Precautions:}

'Always read all of the information on the product label before using any pesticide. Read the label for application restrictions.

Timing of Application: Consult product label for precise timing guidelines for various soil and foliar treatments of picloram formulations. Do not apply picloram on snow or frozen ground.

Drift Control: Do not allow careless application or spray drift. Do not permit spray or spray drift to contact desirable plants.

\section{ENVIRonmental EFfects/Fate}

Soll:

Residual Son Activity: Picloram can stay active in soil for a moderately long time, depending on the type of soil, soil moisture and temperature. It may exist at levels toxic to plants for more than a year after application at normal rates. The half-life of picloram has been reported to vary from one month under favorable environmental conditions, to more than four years in arid regions (USDA, 1984).

ADSORPTION: Picloram chemically attaches to clay particles and organic matter. If the soil has little clay or organic matter, picloram is easily moved by water. 
Persistence and Agents of Degradation: Long-term build-up of picloram in the soil generally does not occur. Break-down caused by sunlight and microorganisms in the soil are : the main ways in which picloram degrades in the environment. Picloram will dissipate more quickly in warm, wet weather. Alkaline conditions, fine textured clay soils, and a low density of plant roots can increase the persistence of picloram.

Metabolites/Degradation Products and Potential Environmental Effects: Carbon dioxide is the major end-product of the breakdown of picloram in the soil. Carbon dioxide is a gas normally found in the air. The relatively small amount from picloram breakdown would not be expected to have any harmful effect on the environment.

One study of picloram breakdown in soil identified two compounds produced in minor amounts: 4-amino-3,5-dichloro-6-hydroxypicolinic acid; 4-amino-2,3,5-trichloro-pyridine. These compounds have also been found as metabolism products of picloram in plants. The study found that these products are not part of the main breakdown pathway in soil, and they do not accumulate in soil (DowElanco Publication e, Mullison. Undated).

\section{WATER:}

SolubiLtTy: Picloram dissolves readily in . water.

Potential for Leaching into Groundwater: The mobility of picloram in soil is characterized by EPA as intermediate to very mobile in soils ranging in texture from clay to loam. Picloram movement is greatest for soils with low organic matter content, alkaline soils, and soils which are highly permeable, sandy, or light-textured.

Picloram can travel through soil, and under certain conditions has the potential to contaminate groundwater. Do not apply picloram where:
Soils have a rapid to very rapid permeability (such as loamy sand to sand) and the water table of an underlying aquifer is shallow; OR:

Soils contain sinkholes over limestone bedrock, severely fractured surfaces, and substrates which would allow direct introduction into an aquifer (DowElanco Publication a. Undated).

Surface Waters: Picloram can be carried by surface run-off water. To prevent water pollution, picloram spray drift or run-off should not be allowed to fall onto banks or bottoms of irrigation ditches, or water intended for drinking or household use. Picloram should not be applied directly to water or wetlands, such as swamps, bogs, marshes or potholes.

AIR:

Volatilization: Picloram does not evaporate easily, but its vapor has been shown injurious to plants. In a closed container, picloram vapors damaged plant seedlings (Gentner, 1964).

Potential for By-Products from Burning of Treated Vegetation: More than $95 \%$ of picloram residue is destroyed during burning. At $225^{\circ} \mathrm{C}$, picloram decomposed to 4-amino2,3,5-trichloropyridine (also found in plant and soil decomposition.). At $900^{\circ} \mathrm{C}$, it decomposed to carbon dioxide, carbon monoxide, chlorine gas, hydrogen chloride, and ammonia. No organochlorine compounds were detected (Dost, 1984). Under fire conditions, Tordon $\circledast \mathrm{K}$ produces hydrogen chloride and nitrous oxides (DowElanco Publication $b$. 1990).

By-products from burning plants treated with picloram have not been identified in the field. 


\section{ECOLOGICAL EFFECTS}

Please refer to Section $\mathrm{X}$ for definitions of ecotoxicological categories.

Son Microorganisms: Picloram has very low toxicity to soil microorganisms at up to 1,000 parts per million. No studies of effects of the picloram formulations were reported.

Plants: Picloram is highly toxic to many nontarget plants. Most grasses are resistant to piclo-. ram. Picloram is active in the soil and can pass from soil into growing plants. It can move from treated plants, through the roots, to nearby plants. Irrigation water polluted with picloram may damage or kill crop plants.

Aquatic Animals: Picloram is moderately to slightly toxic to freshwater fish, and slightly toxic to aquatic invertebrate animals. Picloram was found to reduce fry survival and lake trout growth at the lowest level tested (35 ppb) (Woodward, 1976).

ACUTE TOXIC LEVEL:

\section{Species}

fish invertebrates 4.0 to $24.0 \mathrm{ppm}$ 10.0 to $68.3 \mathrm{ppm}$

The Tordon $\circledast 22 \mathrm{~K}$ formulation has been tested for acute toxicity in numerous aquatic animals. Formulation tests indicated no greater toxicity than previously cited for picloram (DowElanco Publication e; Mullison. Undated).

Picloram does not build up in fish.

Terrestrial Animals: Picloram is practically non-toxic to birds. It is practically non-toxic to bees. Picloram is slightly toxic to practically nontoxic in mammals. Animals excrete most picloram in the urine, unchanged. Picloram and its formulations have not been tested for chronic effects in wildlife species.
ACUTE TOXIC LEVEL:

Species

LD50

\begin{tabular}{cc} 
Species & LD50 \\
\hline birds & $2,000 \mathrm{mg} / \mathrm{kg}$ \\
mammals & 950 to $8,200 \mathrm{mg} / \mathrm{kg}$
\end{tabular}

48-hour contact toxicity to bees $=14.5$ micrograms per bee.

Tordon $\otimes 22 \mathrm{~K}$ has been tested for acute oral toxicity to birds; it is considered practically nontoxic. Tordon $822 \mathrm{~K}$ did not cause any reproductive or developmental effects in chickens when sprayed on fertilized eggs (EPA, 1985).

No tests of formulations for acute toxicity to wildlife mammals have been reported. Picloram and its formulations have not been tested for chronic toxicity to wildlife mammals. A New Zealand study found a possible association of sheep grazing of picloram-treated pastures with increased intestinal cancer. The relationship was inconclusive because of the small number of sheep exposed only to picloram (Newell, et. al., 1984).

Testing on laboratory mammals of picloram and its formulations is reported in Section V.

Threatened and Endangered Species: Picloram may be a hazard to endangered plants when used on pastures, rangeland and forests. Picloram may be a hazard to some endangered invertebrates if it is applied to areas where they live. It is not expected to be a hazard to other endangered animals or birds. 


\section{Health Effects Testing}

The data are results of laboratory animal studies. For picloram, the Environmental Protection - Agency has evaluated these studies during the registration process. Pure picloram can be produced in several forms (acid, potassium salt, etc.). Acute toxicity test results are cited for the potassium salt, which is the only form of picloram used in Tordon® $\mathrm{K}$ and $22 \mathrm{~K}$ formulations. Chronic toxicity results are cited for either the potassium salt, or for the acid, which is considered comparable by EPA.

For DowElanco formulations containing picloram as the only active ingredient (Tordon $\circledast \mathrm{K}$ and Tordon(122K), findings are from studies conducted by the manufacturer (DowElanco e, Mullison. Undated). These studies have been presented to EPA to support product registration, but may not be available to the public.

Formulation tests are noted for each category of acute toxicity. Numerical results are only noted for tests of formulations which showed significantly greater toxicity than pure picloram.

ACUTE TOXICITY:

Acute Oral Toxacity (Median lethal dose):

$$
\begin{aligned}
& \text { Male rats } \quad>5,000 \mathrm{mg} / \mathrm{kg} \\
& \text { Practically Nontoxic (Category IV) } \\
& \text { Female rats } \quad 3,536 \mathrm{mg} / \mathrm{kg} \\
& \text { Slightly Toxic (Category III) }
\end{aligned}
$$

Tordon® $\mathrm{K}$ and Tordon® $22 \mathrm{~K}$ have been tested. Both were classified as Practically Nontoxic.

Acute Dermal Toxicrty (Median Lethal Dose in rabbits):

$$
\begin{aligned}
& \text { Picloram }>2,000 \mathrm{mg} / \mathrm{kg} \\
& \text { Slightly Toxic (Category III) }
\end{aligned}
$$

Tordon ${ }^{\circledR} 22 \mathrm{~K}$ was also found to be a Category III dermal toxicant (USDA, 1984); (DowElanco b, 1990).
Primary Irritation Score (tests in rabbits):

\section{Picloram}

Not an irritant. (Category IV)

The $\mathrm{K}$ salt form of picloram is considered a skin sensitizer (EPA, 1988).

Tordon® $22 \mathrm{~K}$ was found to cause skin irritation or búrn from prolonged or repeated exposure (DowElanco c, 1990 ).

Primary Eye Irritation (tests in rabbits):

\section{Picloram}

Moderate eye irritant. (Category III)

Tordon $\otimes 22 \mathrm{~K}$ has also been categorized as a Category III eye irritant. Though severe irritation may occur, it is reversible (DowElanco c, 1990).

AcuTE INHALATION; Median Lethal Concentration: study in male rats:

$$
\begin{aligned}
& \text { Picloram . } \\
& \text { Moderately Toxic (Category II) }
\end{aligned}
$$

No adverse effects were observed in rats during seven hours' exposure to a Tordon $\$ 22 \mathrm{~K}$-saturated atmosphere, and for two weeks thereafter (USDA, 1984.)

\section{Chronic Toxicity:}

These data are also based on tests in laboratory animals. EPA requires these tests only for the active ingredient picloram. No tests of formulations for chronic toxicity have been reported. Please refer to Section $X$ for an explanation of how NOEL (No Observable Effects Level) is calculated.

The Pacific Northwest Region FEIS (Final Environmental Impact Statement) risk assessment evaluated the quality of the testing that had been done on picloram up to 1988 . Quality consideration for individual studies included: ranges of doses and species that were tested; length of test; identification of the most sensitive effect. Additionally, the degree of quantitative agreement 
among all test for an effect was considered. Please refer to Section $\mathrm{X}$ for an explanation of qualitative ratings in this section.

\section{Systemic Toxicity:}

NOEL for picloram: $7 \mathrm{mg} / \mathrm{kg} /$ day (rat and mice tests).

Increased liver weight was the observed toxic effect.

The PNW Region FEIS rated the quality of testing as Adequate.

\section{Carcinogenicity:}

The potential for causing tumors (oncogenicity) has not been determined at this time. EPA has not accepted available studies; dose levels were not as great as required, and the picloram used in these studies contained unacceptably high levels of a contaminant. EPA requires the mouse and rat oncogenicity tests to be repeated.

The PNW Region FEIS rated the quality of testing as Marginally Adequate.

\section{Mutagenicity:}

Picloram was negative in two tests for mutagenicity (the ability to cause genetic damage). EPA requires submission of data and raw report materials before accepting one of these studies. A third category of testing has not been done.

The PNW Region FEIS rated the quality of testing as Marginally Adequate.

\section{REPRODUCTION/DEVELOPMENTAL:}

Developmental: A study in rats indicated no. evidence of teratology (birth defects). A study in rabbits indicated a NOEL of $40 \mathrm{mg} / \mathrm{kg}$; reduced weight gain of the fetus was the observed effect. The Environmental Protection Agency requires repeated teratology studies in rats and rabbits.

ReProduction: A multi-generation reproduction study in rats did not show any adverse effects on reproduction at doses up to $150 \mathrm{mg} /$ $\mathrm{kg}$ per day. The Environmental Protection Agency requires a repeated study, using more test animals, and a greater range of doses to. establish a toxic effect level.

The PNW Region FEIS evaluated the testing as Marginally Adequate for these effects.

\section{Other Possible Health Effects}

There was insufficient information available to evaluate the potential for effect to the nervous or immune systems. No studies of picloram effects were reported.

\section{Human Health Effects}

\section{Forest Service Evaluation of Human Health RISKs:}

The Pacific Northwest Region evaluated a range of picloram health effects data, including laboratory studies cited in Section V. Both quantitative (numerical) estimates of toxicity, and the quality of data used to make numerical estimates were evaluated.

The FEIS Quantitative Risk Assessment predicts the amount of human exposure-both to project workers and to the public-from typical forestry operations, and also from a large accidental spill. The Risk Assessment used this information to assess health risks from typical uses. These risks were compared to EPA standards of acceptable risk for human health effects. The FEIS risk assessment identified as "Moderate" or "High" any predicted risks from Forest Service operations that were greater than EPA standards. Specific mitigation measures were designed to reduce human exposure from these operations; they are mandatory for every applicable project on $\mathrm{Na}$ tional Forest lands.

The complete set of risk ratings is displayed in Section X. 
The quality of the existing data affects the reliability of these risk ratings. The FEIS judged the overall quality of available data on picloram toxicity to be "Adequate": studies are of sufficient quality and quantity that estimates are considered reliable; new studies are unlikely to change estimates of health effects.

\section{Potential for Health Effects to the Public:}

Forest visitors and nearby residents could be exposed to herbicide drift, to vegetation with herbicide residues, and to accidental spraying. They also could eat food or drink water containing herbicide residues. No studies of public exposure were available; public doses were estimated based on the behavior of the herbicide in the environment. "Routine Application" estimates maximum possible public exposure under normal operating conditions. No "Moderate" or "High" risks to public health were identified for routine application. The "Large Spill" situation models the highest doses that could ever be reasonably be expected to occur. Typical public exposures and risks would be much lower than either situation.

\section{Mrtigating Measures to Reduce Picloram Rusks to Public:}

"High" risk of general health effects, and "Moderate" risk of reproductive effects if exposed to concentrated picloram from a large spill:

Prevent all public contact with accidental spills (emergency spill notification system, restrict public access to spill site).

\section{Probabiltiy of a Worker Receiving a Dose Which Affects General Health or REPRODUCTION:}

Worker exposure and dose are estimated for typical forestry applications. Studies are available that measure actual worker doses of herbicide for some typical forestry applications. Worker doses do not account for any reduction in exposure from following safety precautions or mitigating measures (such as wearing protective clothing).
Mitigating Measures to Reduce Identified Picloram Risks to Workers:

The R6 FEIS did not identify any specific mitigating measures to reduce exposure in Picloram applications. The probability of worker exposure to a toxic concentration for either general health or reproductive effects was rated "Negligible" for all application methods.

Mitigating Measure 13 requires workers applying any herbicide to wear protective clothing. Mitigating Measure 23 requires worker and public exposure monitoring for all herbicide application projects.

\section{Acute Human Health Effects:}

Cases of eye and skin irritation have been reported in workers exposed to picloram formulations.

\section{Long Term Human Health Effects:}

There are no reported cases of long term health effects in humans due to picloram or its formulations.

\section{Potential for Adverse Health Effects from INERT INGREDIENTS CONTAINED IN THE Formulated Product:}

The manufacturer has not revealed the identity of the inert chemicals other than water in these formulations. Specific toxicity information is not available for every inert ingredient. No ingredient in any picloram formulation was categorized by EPA to have evidence or suggestion of toxic effects. Picloram inert ingredients were categorized as either: low priority for health effects testing based on absence of data or chemical structure suspected to cause toxic effects (List 3); or generally recognized to be safe (List 4).

\section{Health Effects of Exposure to Formulated Products:}

No serious health effects in humans have been verified. A few cases of eye irritation and skin irritation from exposure to picloram formulations have been reported. 


\section{Health Effects Associated WITH Contaminants:}

Picloram, when commercially produced, is contaminated with HCB (hexachlorobenzene). HCB is classified by EPA as a Probable Carcinogen; it also had toxic effects to nursing rat pups. After the PNW Region FEIS was prepared, EPA published a health risk assessment for HCB from picloram application. Both public (dietary) and worker exposures were estimated at a HCB contamination level of $200 \mathrm{ppm}$. DowElanco has informed EPA that HCB contamination has been reduced to a maximum of $100 \mathrm{ppm}$ (DowElanco $f$, 1992). EPA considers the risks from HCB to be within acceptable limits (EPA, 1988a). The estimated risks to forestry workers from $\mathrm{HCB}$ exceed the risks identified for picloram in the FEIS. The estimates are within acceptable limits of the FEIS, providing that Mitigating Measure \#13 (required protective clothing) is followed.

EPA has required testing of some picloram formulations for level of nitrosamine contaminants, because of chemicals used in the formulation process. Tordon $\otimes \mathrm{K}$ and $22 \mathrm{~K}$ do not use these chemicals; no testing is required (US-EPA, 1988a).

\section{Health Effects Assoclated with Other FORMULATIONS:}

Some formulations contain picloram mixed with the herbicides $2,4-\mathrm{D}$ or triclopyr. Information Profiles for 2,4-D or Triclopyr will describe the properties and potential effects of these herbicide ingredients.

None of the profiles on individual herbicides fully describe the potential for health or environmental effects from the formulations containing multiple herbicides. Additional information on the properties and potential effects of these formulations will be prepared before they are used in the PNW Region.

\section{Societal Perceptions:}

Public opinion about herbicide use in general ranges from a perception that herbicides are completely safe, to a perception that they are very hazardous. A full range of opinion is available in the FEIS. Beginning in 1992, the PNW Region will publish a bibliography of recent anecdotal and scientific accounts, and an analysis of re- . ported worker health effects. These information packages will be updated to reflect the results of these reviews as needed.

\section{Saféty Precautions:}

\section{Signal Word and Definition:}

Tordon® K: WARNING. Causes substantial but temporary eye injury. Harmful if inhaled or absorbed through skin.

Tordon® 22K: WARNING. Causes substantial but temporary eye injury. Harmful if inhaled or absorbed through skin.

Protective Precaútions for Workers: Do not get picloram in eyes or on clothing. Wear goggles, face shield or safety glasses when handling picloram. Avoid contact with skin. Wash thoroughly with soap and water after handling picloram. After using piclorám, remove and wash clothing before reuse. Do not drink picloram solution. Avoid breathing spray mist.

Medical Treatment Procedures (Antwotes): No specific antidote to picloram is known; treat symptoms. For exposure to the eyes, flush with plenty of water for at least 15 minutes. Get medical attention. For exposure to the skin, wash with plenty of soap and water. Get medical attention if irritation persists. In case of emergency, call your local poison control center for advice. 
Handling, Storage and Disposal: Picloram is stable under normal storage conditions for at least two years. Do not ship or store with food, animal feeds, drugs or clothing.' Dispose of by burying in a non-cropland area away from water supplies, or dispose of in a landfill approved for pesticides in accordance with applicable federal, state and local regulations.

Emergency (Spill) Hazards and Procedures: Absorb spills in inert material such as kitty litter or sawdust. For large spills, dike area to contain spill; consult manufacturer for clean-up. In case of a large spill, call CHEMTREK at 1-800-4249300 for advice.

\section{DEFINTTIONS}

acute toxicity - The amount of a substance, as a single dose, to cause poisoning in a test animal

adsorption - the process of attaching to a surface

basal treatment - applied to the stem of a plant just above the soil

broadcast application - applied over an entire area

carcinogenicity - ability to cause cancèr

chronic toxicity - Toxic effects produced in test animals exposed for long periods to a chemical

dermal - of, or related to, the skin

EC50 - the concentration which will cause a toxic effect in $50 \%$ of the subjects

FEIS - Final Environmental Impact Statement

formulation - the form in which the pesticide is supplied by the manufacturer for use

herbicide - a substance used to destroy plants or to slow down their growth

LC50 - the concentration in air or water which will kill $50 \%$ of the subjects
LD50 - the dose which will kill 50\% of the subjects

leach - to dissolve out by the action of water

$\mathrm{mg} / \mathrm{kg}$ - milligrams of the substance per kilogram of body weight

mg - milligrams of dissolved substance per liter of water

microorganisms - living things too small to be seen without a microscope

mutagenicity - ability to cause genetic changes

non-target - animals or plants other than the ones which the pesticide is intended to kill

persistence - tendency of a pesticide to remain in the environment after it is applied

ppb - parts per billion parts

ppm - parts per million parts

residual activity - the remaining amount of activity as a pesticide

teratogen - a compound having the property of causing birth defects

volatility - the tendency to become a vapor at relatively low temperature

\section{INFORMATION SOURCES:}

Pacific Northwest Region, Forest Service, U.S. Department of Agriculture. 1988. Final Environmental Impact Statement for Managing Competing and Unwanted Vegetation.

Chapter IV, Environmental Consequences: Human Health Effects Characterization and Management of Risk

Appendix C: Herbicide Use and Efficacy

Appendix D: Quantitative Risk Analysis

Appendix J: Herbicide Review with Wildlifeoriented Effects 
U.S. Environmental Protection Agency, Office of Pesticides and Toxic Substances. 1988. Guidance for the Reregistration of Pesticide Products Containing Picloram as the Active Ingredient. EPA Publication No. 540/RS-88132, 1988a.

U.S. Environmental Protection Agency, Office of Pesticides and Toxic Substances. 1988b. Pesticide Fact Sheet: Picloram. EPA Publication No. 540/FS-88-133, 1988.

U.S. Environmental Protection Agency, Office of Pesticides and Toxic Substances. 1985. Science Chapters in Support of the Registration of Picloram, Ecological Effects Profile, $S C-13 C$.

U.S. Environmental Protection Agency, Office of Drinking Water. 1988c. Picloram Health Advisory.

Forest Service, U.S. Department of Agriculture. 1984. Pesticide Background Statements. Volume 1. Herbicides. Agriculture Handbook No. 663.

Dowelanco Publications:

a. Ingredient Lists for Products Containing Picloram, 1992.

b. Product Labels: Tordon $® K$; Tordon $®$ $22 K$. Undated.

c. Material Safety Data Sheet: Tordon $® K$ and 22K. 1990.

d. Picloram Technical Information Guide. Undated.

e. Mullison, Dr. Wendell R. Undated. $A$ Toxicological and Environmental Review of Picloram.

f. Personal communication, V. Carrithers, DowElanco Technical Representative. 1992.
Dost, Frank N. 1984. Combustion of Herbicides. Unpublished Report for Bonneville Power Administration, U.S. Department of Energy.

Gentner, W.A. 1964. Herbicidal Activity of Vapors of 4-amino-3,5,6-trichloropicolinic Acid. Weeds 12: 239-240.

Newell, K.W., A.D. Ross, and R.M. Renner. 1984. Phenoxy and Picolinic Acid Herbicides and Small-intestinal Adenocarcinoma - in Sheep. Lancet: December 8, 1984: 13011305.P

Norris, Logan A. 1982. Accuracy and Precision of Analyses for 2,4-D and Picloram in Water by Contract Laboratories. Unpublished Report for: Pacific Northwest Forest and Range Experiment Station, Forest Service, U.S. Department of Agriculture.

Woodward, D.F. 1976. Toxicity of the Herbicides. Dinoseb and Picloram to Cutthroat and Lake Trout. J. Fish. Res. Board Canada 33: 1671-1676.

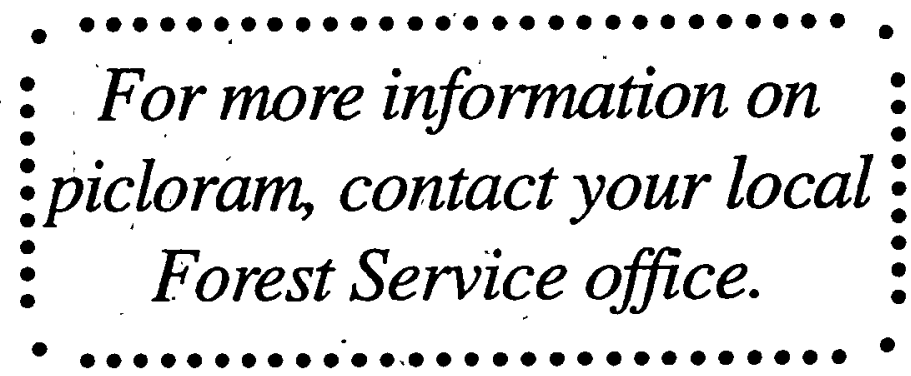

April 1992

This Picloram Information Profile is based on the "Picloram Pesticide Fact Sheet" developed by Information Ventures, Inc., under USDA Forest Service Contract Number 53-3187-104. 


\section{Toxicity and Risk Categories}

Estimates of Health Risks to the public and to WORKERS FROM FOREST SERVICE OPERATIONS

The FEIS predicts levels of human exposure (dose) for project workers and for the public, for both a typical field project and for a large accidental spill. These dose levels are compared to the highest dose level in animal tests that showed no health effect (No Observed Effects Level). The risk is ranked from "Negligible" to "High" based on the margin between the expected human dose and the highest NOEL_-noeffect" dose. A "High" risk rating means that the highest NOEL dose is not more than ten times larger than predicted human dose under the specified conditions. A "Moderate" risk rating means that the highest NOEL dose is between 10 and 100 times larger than the expected human dose.

\begin{tabular}{|c|c|c|}
\hline \multicolumn{3}{|c|}{$\begin{array}{c}\text { Estimated Health Risks } \\
\text { To The Public }\end{array}$} \\
\hline Situation & $\begin{array}{c}\text { General } \\
\text { Health }\end{array}$ & Reproduction \\
\hline $\begin{array}{c}\text { Routine } \\
\text { Application }\end{array}$ & Low & Negligible \\
\hline Large Spill & High & Moderate \\
\hline
\end{tabular}

\begin{tabular}{|c|c|c|}
\hline \multicolumn{3}{|c|}{$\begin{array}{c}\text { Estimated Health Risks } \\
\text { To Project Workers }\end{array}$} \\
\hline Situation & $\begin{array}{c}\text { General } \\
\text { Health }\end{array}$ & Reproduction \\
\hline $\begin{array}{c}\text { Aerial } \\
\text { Mixer/Loader }\end{array}$ & Negligible & Negligible \\
\hline $\begin{array}{c}\text { Backpack } \\
\text { Sprayer }\end{array}$ & Negligible & Negligible \\
\hline $\begin{array}{c}\text { Right-of-way } \\
\text { Mixer/Loader }\end{array}$ & Negligible & Negligible \\
\hline $\begin{array}{c}\text { Hack-and } \\
\text { Squirt }\end{array}$ & Negligible & Negligible \\
\hline
\end{tabular}

Ecotoxological Categories

\begin{tabular}{|c|c|}
\hline \multicolumn{2}{|c|}{ Mammalian (Acute Oral): } \\
\hline$m g / k g$ & Risk Category \\
\hline$<10$ & very highly toxic \\
\hline $10-50 \cdot$ & highly toxic \\
\hline $51-500 \cdot$ & moderately toxic \\
\hline $501-2000$ & slightly toxic \\
\hline$>2000$ & practically non toxic \\
\hline
\end{tabular}

\begin{tabular}{|c|c|}
\hline \multicolumn{2}{|c|}{ Avian (Acute Oral): } \\
\hline $\boldsymbol{m g} / \mathrm{kg}$ & Risk Category \\
\hline$<10$ & very highly toxic \\
\hline $10-50$ & highly toxic \\
\hline $51-500$ & moderately toxic \\
\hline $501-2000$ & slightly toxic \\
\hline$>2000$ & practically-non toxic \\
\hline
\end{tabular}

\begin{tabular}{|c|c|}
\hline \multicolumn{2}{|c|}{ Avian (Dietary): } \\
\hline$p p m$ & Risk Category \\
\hline$<50$ & very highly toxic \\
\hline $50-500$ & highly toxic \\
\hline $501-1000$ & moderately toxic \\
\hline $1001-5000$ & slightly toxic \\
\hline$>5000$ & practically non toxic \\
\hline
\end{tabular}

\begin{tabular}{|c|c|}
\hline \multicolumn{2}{|c|}{ Aquatic Organisms: } \\
\hline ppm & Risk Category \\
\hline$<0.1$ & very highly toxic \\
\hline $0.1-1$ & highly toxic \\
\hline$>1-10$ & moderately toxic \\
\hline$>10-100$ & slightly toxic \\
\hline$>100$ & practically non toxic \\
\hline
\end{tabular}




\section{TABLE of CATEgories of ToXICITY}

\begin{tabular}{|c|c|c|c|c|}
\hline \multicolumn{5}{|c|}{ Human Hazards } \\
\hline & & \multicolumn{3}{c|}{ Route of Administration } \\
\hline Risk Category & Signal Word & $\begin{array}{c}\text { Oral } \\
(\mathbf{m g} / \mathbf{k g})\end{array}$ & Dermal (mg/kg) & $\begin{array}{c}\text { Inhalation } \\
(\mathbf{m g} / \mathbf{k g})\end{array}$ \\
\hline I & DANGER--Poison & $0-50$ & $0-200$ & $0-0.2$ \\
\hline II & WARNING & $>50-500$ & $>200-2000$ & $>0.2-2.0$ \\
\hline III & CAUTION & $>500-5000$ & $>2000-20,000$ & $>2.0-20$ \\
\hline IV & NONE & $>5000$ & $>20,000$ & $>20$ \\
\hline
\end{tabular}

\begin{tabular}{|c|c|c|}
\cline { 2 - 4 } \multicolumn{1}{c|}{} & \multicolumn{2}{c|}{ Hazard } \\
\hline Category & Eye Irritation & Skin Irritation \\
\hline I & $\begin{array}{c}\text { Corrosive: corneal opacity not reversible within 7 } \\
\text { days }\end{array}$ & corrosive \\
\hline II & $\begin{array}{c}\text { corneal opacity reversible within 7 days; irritation } \\
\text { persisting for 7 days }\end{array}$ & $\begin{array}{c}\text { severe irritation } \\
\text { at 72 hours }\end{array}$ \\
\hline III & $\begin{array}{c}\text { no corneal opacity; irritation reversible } \\
\text { within 7 days }\end{array}$ & $\begin{array}{c}\text { moderate irritation } \\
\text { at 72 hours }\end{array}$ \\
\hline IV & no irritation & $\begin{array}{c}\text { mild or slight irritation } \\
\text { at 72 hours }\end{array}$ \\
\hline
\end{tabular}

\section{Categories of Quality of Health Effects Data}

Inadequate:

MarginalInadequate:

Adequate:
Inadequate information available for evaluating toxicity. There were too few studies of sufficient quality to yield useful or reliable information.

Some useful information exists for evaluating toxicity. There were studies of marginal quality that provided useful information, but studies were inconsistent and some contained flaws. It is likely that new studies would change estimates of health effects.

Marginal but useful information available for evaluating toxicity. There were studies of adequate quality, and results did not vary greatly, but more information would increase reliability. Although new studies may change estimates of health effects, the results are considered moderately reliable.

Adequate information is available. Studies are of sufficient quality and quantity that estimates of human health are considered reliable. New studies are unlikely to change estimates of health effects. 


\section{Dicamba}

\section{Herbicide Information Profile}

This information profile is produced by the USDA Forest Service, Pacific Northwest Region, for employees, forest workers, and for the public. It provides information on forest and land management uses, environmental and human health effects. and safety precautions for the herbicide dicamba and its formulations. A list of definitions is included in Section VIII of the information profile. For general information on herbicide use by the Forest Service, refer to the PNW Rcgion Treatment Methods Profile for Herbicides.

The principal sources of information and findings in this profile are the PNW Region FEIS (Final Environmental Impact Statement) for Managing Competing and Unwanted Vegetation: Forest Service "Herbicide Background Statement: Dicamba": and product labels and Material Safety Data Sheets. Information from other sources is referenced in the profile.

\section{BASIC INFORMATION}

COMmON Name: dicamba

Chemical Name: 3.6-dichloro-Q-anisic acid

Product Names: Banvel ${ }^{\oplus}$ and Vanquish ${ }^{\oplus}$ products for forestry and noncrop sites

Pesticide Classtfication: herbicide
Registered Use Status: "General Use"

Formulations: The dicamba products discussed in this profile are formulated from a DMA (dimethylamine) salt or a DGA (diglycolamine) salt. Dicamba formulations contain one or more substances besides dicamba itself. These substances are called inert ingredients, because they do not kill plants by themselves. The identities of inert ingredients are not usually listed on the label.

The manufacturer revealed the identity of all incrts to EPA (U.S. Environmental Protection Agency). The Forest Service has asked the manufacturer to identify all inert ingredients for public disclosure in this profile. The manufacturer has not publicly identified some inert ingredients contained in these formulations. Hazardous inert ingredients (as defined by U.S. Occupational Health and Safety Administration) have been publicly identified.

Where the manufacturer has not publicly identified inert ingredients, this profile may not fully characterize possible hazards to human health and the environment associated with a dicamba formulation. 
Manufactured by Sandoz:

\section{Banvel ${ }^{\star}$ or Banvel ${ }^{\Phi} 4 S$}

Dicambá, as the DMA salt

$48.2 \%$

DMA salts of related acids

$12.0 \%$

Inert ingredients

$39.8 \%$

\section{Banvel $^{\circledR}$ CST}

Dicamba, as the DMA salt

$13.3 \%$

DMA salts of related acids

$3.3 \%$

Inert ingredients

$83.4 \%$

Ethylene glycol

Unidentified

$30.0 \%$

$53.4 \%$

\section{Vanquish $^{\oplus}$}

Dicamba, as the DGA salt

$56.8 \%$

DGA salts of related acids

$14.2 \%$

Inert ingredients

The results of formulation testing reported in this profile apply only to these Banvel ${ }^{\infty}$ and Vanquish $^{\oplus}$ products. These products contain only dicamba as an active herbicide ingredient.

Other formulated products contain both dicamba and another herbicide. Information in this profile does not address possible effects of these formulated herbicide mixtures.

RestDUE Assay Methods: Several methods have been described for detecting dicamba in water (EPA. 1988; Arjmand et al. 1988; Hamann et al., 1987; Jimenez et al. 1989). EPA reports that the method which detects the lowest concentration of dicamba uses capillary column gas chromatography. Jimenez et al. estimate a detection limit of $0.1 \mathrm{ppb}$, based on average recovery of 84 percent of dicamba actually present in water samples.

EPA found that adequate analytical methods are available for determining residue levels of

dicamba in crop plants. The detection limit for this method is estimated to be $10 \mathrm{ppb}$, based on recoveries ranging from 70 to 120 percent of dicamba actually applied (EPA, 1993a).

Available references did not discuss residue assay methods for dicamba in soils.

\section{HERBICIDE USES}

REGISTERED FORESTRY, RANGELAND; RIGHT-OF-WAY USES: control of annual and perennial broadleaf weeds, brush, and vines in rangeland and noncropland areas. Non-cropland areas include fence rows; roadways, rights-of-way, and non-selective forest brush control (including site preparation).

\section{Operational Détalis:}

Target Plants: Dicamba is used to control broadleaf plants, brush, and vines. Dicamba does not injure grasses at recommended rates.

MODE OF ACTION: Dicamba is absorbed by leaves and roots, and moves throughout the plant. In some plants. it may accumulate in the tips of leaves. Plants respond to dicamba as if it were a growth hormone; dicamba interferes with normal plant growth processes. Some plants can break down dicamba.

METHOD OF APPLICATION: Ground or aerial broadcast, soil (band) treatment, basal bark treatment, stump (cutsurface) treatment, frill treatment, and tree injection, spot treatment.

USE RATES: 0.25 to 8 pounds acid equivalent per acre.

\section{Special Precautions:}

Always read all of the information on the product label before using any pesticide. Read the label for application restrictions.

Timing of Application: Dicamba should generally be applied during periods of active plant growth. Spot and basal bark treatments can be applied when plants are dormant, but 
should not be done when snow or water prevent application directly to the ground.

DRIFT ConTROL: Do not apply dicamba where it may move down in the soil or be washed along the soil surface to roots of desirable plants. Do not apply when air currents could carry spray to desirable plants. Leave buffer zones between area to be treated and desirable plants. Do not apply near desirable plants on days when the temperature is likely to exceed $85 \mathrm{~F}$. Do not apply from aircraft when desirable plants are growing near the area to be treated. Avoid fine sprays.

\section{EnVironmental Effects/Fate}

Soll:

Residual Soll Actrvity: Dicamba may be absorbed by roots from the soil and damage plants.

ADSORPTION: Dicamba does not strongly attach to most soil particles. It is highly mobile in water moving through soil.

Persistence and Agents of Degradation: Dicamba is moderately persistent in soil. Its half-life in soil has ranged from one to six weeks. No studies have been reported for Pacific Northwest forest or rangeland soils.

Soil microorganisms readily break down dicamba. It degrades more rapidly under conditions that favor microbial activity: warm, moist, neutral soils with higher proportions of organic matter.

Dicamba may also volatilize from soils, unchanged; the extent and significance of loss is uncertain (PBS, 1984).

\section{Metabolites/Degradation Products and} Potential ENvironmental EfFects: The main metabolite (break-down product) of dicamba in soil is 3.6-dichlorosalicylic acid. This metabolite is more strongly attracted to soil particles than dicamba, and less likely to move in soil (Comfort, et. al., 1992). Carbon dioxide is one ultimate degradation product.

\section{WATER:}

SoluBILITY: Dicamba salts used in Banvel ${ }^{\oplus}$ and Vanquish ${ }^{\oplus}$ formulations are highly soluble in water.

POTENTIAL FOR LEACHING INTO GROUND-WATER: Dicamba was detected in 2 percent of water samples from over 3000 wells across the United States. No levels of dicamba contamination approached EPA threshold of concern. No dicamba was detected in 151 well samples in Washington and Oregon. (EPA, 1992). The potential for leaching depends on the rate of its movement in soil water versus the rate of degradation by microorganisms to its metabolite, which is less mobile (Comfort, et. al., 1992).

SURFACE WATERS: Dicamba has been found in surface runoff when a rainstorm occured soon after application to agricultural fields in western Washington (Mayer and Elkins. 1990). Reviews of dicamba mobility studies concluded that contamination of surface . waters due to runoff is unlikely except when heavy rainfall occurs soon after application (Ghassemi, et. al., 1981). Dicamba was found in stream waters after aerial application to 166 acres (25 percent) of a Pacific Northwest forest watershed. Concentration rose to a maximum of $37 \mathrm{ppb}$ after 5.2 hours, then dropped to background levels ( $<1 \mathrm{pph})$ after 37.5 hours. The scientists attributed these residues to drift and direct application of dicamba to water instead of surface runoff.

AIR:

Volatilization: Dicamba in Banvel ${ }^{\oplus}$ formulations is relatively volatile. It can evaporate from plant surfaces, and may evaporate from the soil. Crop extension specialists in Colorado report damage from Banvel $^{\oplus}$ volatiliza- 
tion to surrounding sensitive crops. Banvel ${ }^{\circledR}$ was applied when air temperatures were 10 degrees hotter than the maximum temperature allowed by the label. (Westra and Schwarz, 1989)

POTENTIAL FOR By-PRoducts FROM BURNING OF TREATED VegetaTion: Vanquish ${ }^{\circledR}$ may produce amines, hydrochloric acid, organochlorine molecules, and oxides of nitrogen.

Banvel $1^{\Phi}$ may produce these same compounds, and also steam and carbon monoxide.

\section{ECOLOGICAL EFFECTS}

\section{Non-TARget Toxicity:}

Soll Microorganisms: When 50 ppm dicamba was applied to laboratory cultures of soil microorganisms, reduction in growth was shown for some species. No studies of dicamba formulations have been reported.

PLANTS: Dicamba is toxic to many broadleaf plants and to conifers. It does not injure most grasses. Dicamba DMA salt had a half-life of two weeks in one study of range forage grasses.

AQUATIC ANIMALs: Dicamba has been tested for acute toxicity to a variety of aquatic animals. The studies accepted by EPA found dicamba acid and DMA salt to be practically non-toxic to aquatic invertebrates. Slight toxicity to specific crustaceans was reported in three tests of unknown quality not used by EPA. Studies accepted by EPA found dicamba acid to be slightly toxic to coldwater fish (rainbow trout), and practically non-toxic to warmwater fish. Other studies are generally consistent with EPA findings, but variable. Banvel ${ }^{\oplus}$ formulations discussed in this profile have been tested for acute toxicity to a variety of aquatic animals. All were categorized as practically nontoxic. EPA did not require additional testing for $V_{\text {anquish }}{ }^{\oplus}$, based on the low toxicity and bioaccumulation found in Banvel $^{\circledR}$ testing. Dicamba did not bioaccumulate in tests on aquatic animals in an aquarium simu- lating an aquatic ecosystem. Dicamba and its formulations have not been tested for chronic toxic effects, or behavioral changes in aquatic animals.

TerRestrial Animals: Based on acute toxicity tests, dicamba acid is classified as practically nontoxic to duck and quail. In eight-day feeding studies, formulated dicamba acid and salts were found to be practically nontoxic to duck and quail. The LC50 for mallard eggs which had been immersed in $\mathrm{Banvel}^{\oplus}$ was reported to be more than 200 times greater than the field application rate. Eye malformations and stunted growth were observed at unspecified application rates lower than the LC 50 (Hoffman and Albers 1984).

Based on acute toxicity tests dicamba is classified as slightly toxic to mammals. Banvel ${ }^{\otimes}$ formulations were found to be less toxic to laboratory mammals than dicamba alone. No tests of formulations for acute toxicity to wildlife mammals have been reported. Dicamba and its formulations have not been tested for chronic. effects in wildlife mammals.

Both feeding and contact studies generally indicated a low toxicity of dicamba and Banvel ${ }^{\oplus}$ $4 \mathrm{~S}$ to honey bees. German cockroaches were unaffected by any dose up to $1000 \mathrm{ppm}$ in food.

In mammals, most dicamba is excreted, unchanged, in the urine. Studies of dicamba accumulation in animals dosed by various routes indicate that it does not bioaccumulate.

Livestock may graze dicamba-treated areas without restriction, unless they are actively producing milk. Meat animals must be removed from treated areas 30 days prior to slaughter.

ThreATENED ANd ENDANGered SPECIES: Dicamba may be a hazard to endangered plant species if it is used in areas where they live. EPA does not consider dicamba in current use patterns to be a hazard to endangered animal species. 


\section{Health Effects Testing}

The data are results of laboratory animal studies. These data have been evaluated by the Forest Service and are used to make inferences relative to potential human health effects.

For dicamba and formulations containing dicamba as the only active ingredient, findings are from studies conducted by the manufacturer. These studies have been presented to EPA to support product registration, but may not be available to the public. Formulation tests are noted for each category of acute toxicity. Test results are only shown when formulations showed greater toxicity than dicamba alone.

\section{Acute Toxicity:}

ACUTE ORAL ToxicITY: In tests in rats, the lowest median lethal dose was $1140 \mathrm{mg} / \mathrm{kg}$. Slightly Toxic (Category III) Another study found comparable toxicity, however the median lethal dose for female rats was less than for male rats (Gaines, T. and Linder, R. 1986).

The formulations listed in this profile have been tested and found to be less toxic than dicamba itself.

Acute Dermal Toxicrty: Toxicity of dicamba applied directly to skin was greater than $2.0(0)$ $\mathrm{mg} / \mathrm{kg}$ in rats. Slightly Toxic (Catcgory III).

All formulations have been tested and found to be no more toxic than dicamba itself.

PRIMARY IRRTtation Score: Dicamba was slightly irritating to the skin of rabbits in laboratory tests. (Toxicity Category IV).

The formulations listed in this profile have been tested. Only Banvel ${ }^{\Phi}$ was more irritating than dicamba itself. Moderate irritant (Category III)

PrIMARY EYe IRRITATION: In laboratory tests in rabbits, dicamba was extremely irritating and corrosive to eyes. (Toxicity Category I)
The formulations listed in this profile have been tested and found to be less irritating than dicamba itself.

ACUTE INHALATION; (study in rats): In tests in rats, the lowest toxic inhalation concentration was 9.6 mig/l. Slightly Toxic (Category III)

The formulations listed in this profile have been tested. Only Banvel ${ }^{\circledR}$ CST was more toxic (LC50 $=5.14 \mathrm{mg} / 1$ )than dicamba itself.

\section{Chronic Toxicity:}

These data are also based on tests in laboratory animals. EPA requires these tests only for the active ingredient dicamba. No tests of formulations for chronic toxicity have been reported. Please refer to Section X for an explanation of how NOEL (No Observable Effects Level) is calculated.

The Pacific Northwest Region FEIS risk assessment evaluated the quality of the testing that had bcen done on dicamba up to 1988. Quality consideration for individual studies included: ranges of doses and species that were tested; length of test; identification of the most sensitive effect. Additionally, the degree of quantitative agreement among all tests for an effect was considered. Please refer to Section $X$ for an explanation of qualitative ratings in this section.

\section{SySTEMIC TOXICITY:}

NOEL FOR DICAMBA: $37 \mathrm{mg} / \mathrm{kg} /$ day (rat feeding study)

Observed effects include liver weight ratio and liver cell changes. One study of mouse liver response to dicamba found a decrease in enzymes that are produced in response to foreign chemicals. Whether the decrease in enzyme production would affect body response to toxins is not known (Moody et. al., 1991)

The PNW Region FEIS rated the quality of testing as Inadequate. Since the 1988 rating, two additional studies have been accepted by EPA. 
improving the quality of available data. A study in dogs and a study in mice both found less systemic toxicity of dicamba than the previouslycited NOEL (EPA, 1987, and EPA, 1989).

\section{Carcinogenicity/Mútagenićrty:}

CARCINOGENICITY: EPA has recently accepted studies in rats and in mice. Dicamba showed no evidence of carcinogenicity in either study including the highest doses tested (respectively, 300 and $360 \mathrm{mg} / \mathrm{kg} / \mathrm{day}$ ) (EPA, 1986, and EPA, 1989).

These studies satisfy EPA data requirements for cancer testing. EPA has not determined whether dicamba can potentially cause cancer.

MUTAGENICITY: Dicamba was not mutagenic (able to cause genetic damage) in 11 out of 13 laboratory tests done for one EPA-accepted study. Two bacterial tests for dicamba damage to DNA were positive. Reviewers considered these two tests to measure toxicity to DNA but not whether mutations would form as a result. They concluded the evidence indicates that dicamba is not mutagenic (Forest Service, 1992)

EPA cites one foreign-language study which reported an increase in chromosome deformation in mouse bone marrow cells exposed to high levels $(50) \mathrm{mg} / \mathrm{kg}$ ) of dicamba. No details or data were presented in the English summary; the significance of the study is unknown (EPA, 1988b). Researchers found that dicamba caused mutations of plant pollen-producing cells at concentrations of $50 \mathrm{ppm}$ and greater (Ma, T. et. al., 1984).

The PNW Region FEIS rated the quality of testing as Marginal for these effects. Since the 1988 rating, the two cancer studics have been accepted by. EPA, improving the quality of available data. These studies found no evidence of cancer-causing potential for dicamba.

\section{REPRODUCTION/DEVELOPMENTAL:}

DEVELOPMENTAL: EPA identified a NOEL of $30 \mathrm{mg} / \mathrm{kg} /$ day for the mother, and $150 \mathrm{mg} / \mathrm{kg} /$ day for the offspring, based on studies in pregnant rabbits (EPA, 1993b). Reduced body weights and increased post-implantation losses were observed at higher dicamba dose levels. This study supercedes a previous study in rats which had a NOEL of $3 \mathrm{mg} / \mathrm{kg} /$ day.

REPRODUCTION: A new rat study found a NOEL of $40 \mathrm{mg} / \mathrm{kg} /$ day, and is currently being reviewed by EPA (Arnold, D., 1993). A three-generation reproduction study in rats did not show any adverse effects on fertility or reproduction at doses up to $25 \mathrm{mg} / \mathrm{kg}$ per day.

The PNW Region FEIS evaluated the testing as Marginal for these effects. Since the 1988 rating, one rabbit study has been accepted by EPA, improving the quality of available data. This study found a lower toxicity of dicamba to both mother and offspring than the previous study used in the FEIS risk assessment.

\section{Other Póssible Health Effects}

Allergic skin reactions to dicamba were studied in guinea pigs to assess immune system effects. Dicamba was judged to cause moderate allergic reactions in guinea pigs (EPA 1988). The PNW Region FEIS evaluated the testing as Inadequate for these effects. The study cited here is new, and would improve the quality of available data for assessing dicamba effects.

The potential for dicamba to damage the nervous system was studied in hens (EPA 1988), and in rats (EPA. 1993c). In hens, some nerve damage was noted for $316 \mathrm{mg} / \mathrm{kg} /$ day. the highest dose tested. In rats, effects were observed at all doses tested. The lowest dose tested was $300 \mathrm{mg} / \mathrm{kg} /$ day. In a recent study, one dog dosed with 86.7 $\mathrm{mg} / \mathrm{kg}$ dicamba exhibited neuromuscular spasm 
activity (Beasley et al, 1991). In a trial of an unaccepted detection method, dicamba appeared to inhibit an enzyme that helps transmit nerve impulses (acetylcholinesterase). This enzyme is inhibited by certain insecticides, and can lead to neurotoxic effects and death. This study was not designed to statistically evaluate dicamba effects, so the significance of this finding is unknown (Potter et.al., 1993). The PNW Region FEIS evaluated the testing as Inadequate for nervous system effects. All cited tests are more recent, and would improve the quality of available information for assessing dicamba effects.

\section{Human Health Effects}

\section{Forest Service Evaluation of Human Health RISKS:}

The Pacific Northwest Region evaluated a range of dicamba health effects data, including some laboratory studies cited in Section V. Both quantitative (numerical) estimates of toxicity, and the quality of data used to make numerical estimates were evaluated. New information presented in Section V would improve the quality ratings in those categories. No new studies indicated a reduced margin of safety which would warrant additional restrictions on use of dicamba beyond those specified in the FEIS.

The FEIS Quantitative Risk Assessment predicts the amount of human exposure-both to project workers and to the public-from typical forestry operations, and also from a large accidental spill. The Risk Assessment used this information to assess health risks from typical uses. These risks were compared to EPA standards of acceptable risk for human health effects. The FEIS risk assessment identified as "Moderate" or "High" any predicted risks from Forest Scrvice operations that were greater than EPA standards. Specific mitigation measures were designed to reduce human exposure from these operations; they are mandatory for every applicable project on National Forest lands. The complete set of risk ratings is displayed in Sec. X.
The quality of the existing data affects the reliability of these risk ratingș. The FEIS judged the overall quality of available data on dicamba toxicity to be "Marginal to Inadequate". There were some studies of marginal quality that provided useful information, but studies were inconsistent and some contained flaws. It is likely that new studies would change estimates of health effects. Very cautious assumptions were made in characterizing risk.

\section{Potential for Health Effects to the Public:}

Forest visitors and nearby residents could be exposed to herbicide drift, to vegetation with herbicide residues, and to accidental spraying. They also could eat food or drink water containing herbicide residues. EPA found dicamba present in 1.4 percent of 6990 urine samples that represented the general U.S. civilian population. Amount of dicamba could not be reliably estimated (Kutz et al, 1992). No studies of public exposure to forest herbicide applications were available. Public doses were estimated based on the behavior of the herbicide in the environment. "Routine Application" estimates maximum possible public exposure under normal operating conditions. The "Large Spill" situation models the highest doses that could ever be reasonably be expected to occur. Typical public exposures and risks would be much lower than either situation.

\section{Mitigating Measures to Reduce Inentified Dicamba Risks to Public:}

"Low" risk of general health effects for all routine projects. "Moderate" risk of reproductive health effects for people who receive multiple . exposures from a large (400-acre) aerial application project. "Low" risk for smaller (40-acre) aerial projects, and for all ground-based applications:

Consider potential for.public exposure when designing contact procedures, posting and signing needs in the Herbicide Application Plan. 
"Moderate" risk of general health effects, and "High" risk of reproductive effects if exposed to concentrated dicamba from a large spill:

Prevent all public contact with accidental spills (emergency spill notification system, restrict public access to spill site).

\section{Probability of a Worker Receiving a Dose Which AfFects General Health or Reproduction:}

Worker exposure and dose are estimated for typical forestry applications. Studies are available that measure actual worker doses of herbicide for some typical forestry applications. Studies of worker exposure in one noxious weed control ground application found up to ten times higher urine residues (Draper, W. and Street, J., 1982). These worker doses do not account for any reduction in exposure from following safety precautions or wearing protective clothing.

\section{Mitigating Measures to Reduce Identified Dicamba Risks to Workers}

The probability of worker exposure to a toxic concentration for general health effects was rated "Low" or "Negligible" for all application methods. The probability of worker exposure to a toxic concentration for reproductive effects was rated "Low" or "Negligible" for aerial and tank truck mixer/loaders; "Moderate" for backpack spray and hack-and-squirt applicators.

In the PNW Region FEIS, Mitigating Measure 13 requires workers applying any herbicide to wear protective clothing. Mitigating Measure 23 requires worker exposure monitoring for all herbicide application projects.

The 1992 Amendment to the ROD requires workers to review this Information Profile before agreeing to apply dicamba herbicides. The worker may request reassignment without.penalty. Additional personal protective equipment will be available at the worksite for workers who want to reduce their exposure to the herbicide.

\section{Acute Toxicity (Poisoning)}

REPORTED EFFECTS: Effects of exposures to dicamba included muscle cramps, difficult breathing, nausea, vomiting, skin rashes, loss of voice, swollen neck glands, coughing and dizziness.

\section{Long Term Human Health Effects:}

REPORTED EFFECTS: There are no reported cases of long term health effects in humans due to dicamba or its formulations.

\section{Potential fór Adverse Health Effects from INERT INGREDIENTS CONTAINED IN THE Formulated Product:}

The manufacturer has identified some inert chemicals in dicamba formulations; other inerts have not been identified to the public. All dicamba inert ingredients have been identified to EPA. EPA classified all inerts into one of four categories, called "Lists". List 1 contains chemicals of known toxic concern. List 2 contains chemicals of suspected toxic concern which are high priority for testing. List 4 contains chemicals of known nontoxic character, generally recognized as safe to humans. All other chemicals were classified on List 3: Inerts of unknown toxicity. EPA did not find enough information available on the toxic properties of List 3 chemicals to classify them on Lists 1, 2, or 4. All inert ingredients used in these Banvel ${ }^{\otimes}$ and Vanquish ${ }^{\otimes}$ formulations were classified by EPA on List 3 or List 4.

The only identified inert ingredient in these dicamba formulations is ethylene glycol (Banvel ${ }^{\circledR}$ CST). Ethylene glycol may cause kidney damage and birth defects. In addition to ingestion or skin absorption, people and animals . may be exposed to ethylene glycol in mists from spray operations, and also to its vapors if applied in hot weather. In four week studies of human volunteers, breathing ethylene glycol in excess of about 22 ppm caused "marked complaints" of health effects. Irritation of the upper resipiratory tract was most common, with headaches and low backache also reported. Another study reported drowsiness from excessive exposure but no 
irritation (ACGIH, 1992). The PNW Region

FEIS did not estimate inhalation exposure levels, based on studies of workers in which inhalation doses were two percent or less of doses from skin absorption.

\section{Health Effects Associated with Contaminants:}

Traces of 2,7-dichlorodibenzo-p-dioxin (up to 50 parts per billion) are formed during production of dicamba. A possible cancer-causing association was found in male mice, but not in female mice, or rats of either sex (Huff, et. al., 1991). The more toxic dioxin 2,3,7.8-tetrachlorodibenzo$\mathrm{p}$-dioxin has not been found at the $2 \mathrm{ppb}$ detection limit, and is not predicted to be an impurity in dicamba.

DMA salt formulations of dicamba (Banvel ${ }^{\oplus}$, Banvel ${ }^{\oplus} \mathrm{CST}$ ) may be contaminated with less than $1 \mathrm{ppm}$ of dimethylnitrosamine. EPA estimates the risk levels for nitrosamine in these dicamba formulations to be less than one in one million (EPA, 1983).

\section{Health Effects Associated with Other Formulations:}

Some formulations contain dicamba mixed with other herbicides such as 2,4-D or atrazine. This profile does not fully describe the potential for health or environmental effects from these formulations containing multiple herbicides. Additional information on properties and potential effects of these formulations will be prepared before they are used in the PNW Region.

\section{Societal Perceptions:}

Public opinion about herbicide use in general ranges from a perception that herbicides are completely safe, to a perception that they are very hazardous. A full range of opinion is available in the FEIS. Beginning in 1992, the PNW Region publishes a bibliography of recent anecdotal and scientific accounts, and analyzes reported worker health effects. This herbicide information profile will be updated to reflect the results of these reviews as needed.

\section{Safety Precautions:}

\section{Signal WoRd ANd Defintrion:}

Banvel $^{\oplus}$ : WARNING - Causes eye irritation. Harmful if swallowed.

Vanquish $^{\oplus}:$ CAUTION - Harmful if swallowed.

- Protective Precautions for Wórkers: Do not get in eyes, on skin, or on clothing. Avoid breathing spray mist. Wash thoroughly after handling.

Medical Treatment Procedures (Antidotes): There is no specific antidote for dicamba; treat symptoms. For exposure to the skin, wash with soap and water. For exposure to the eyes, flush with water for 15 minutes and get medical attention. If inhaled, remove victim to fresh air. Apply artificial respiration if victim is not breathing; get medical attention. If swallowed, give 1 to 2 glasses of water and induce vomiting. Get medical attention. In case of emergency call your local poison control center for advice.

Handling, Storage and Disposal: Dicamba is stable under normal storage conditions. Store in the original container in a well ventilated area separately from fertilizer, animal feeds and food. Do not contaminate water, food, or feeds by storage or disposal. Dispose of waste on site or at an approved waste disposal facility.

Emergency (Spill) Hazards and Procedures: Dike or contain spill. Absorb liquid with absorbent material such as sawdust. Place material in container for later disposal. Observe all local, state, and federal rules for disposal. In case of a large spill, call CHEMTREC at 1-800-424-9300 for advice. 
VIII. Definitions

acute toxicity - The amount of a substance, às a single dose, to cause poisoning in a test animal.

adsorption - the process of attaching to a surface.

basal treatment - applied to the stem of a plant just above the soil.

bioaccumulate - the uptake of a chemical by an organism from its environment.

broadcast application - applied over an entire area.

carcinogenicity - ability to cause cancer.

chronic toxicity - Toxic effects produced in test animals exposed for long periods to a chemical.

dermal - of, or related to, the skin.

EC50 - the concentration which will cause a toxic effect in $50 \%$ of the subjects.

formulation - the form in which the pesticide is süpplied by the manufacturer for use.

half-life - the time required for a chemical to be reduced by natural processes to one half its . original amount.

herbicide - a substance used to destroy plants or to slow down their growth.

LC50 - the concentration in air or water which will kill $50 \%$ of the subjects

LD50 - the dose which will kill 50\% of the subjects.

leach - to dissolve out by the action of water.

mg/kg - milligrams of the substance per kilogram of body weight. Equals ppm. .

mg/l - milligrams of dissolved substance per liter of water. Equals ppm.

microorganisms - living things too small to be seen without a microscope.

mutagenicity - ability to cause genetic changes.

non-target - animals or plants other than the ones which the pesticide is intended to kill.

persistence - tendency of a pesticide to remain in the environment after it is applied.

ppb - parts per billion parts.

ppm - parts per million. Equal to $\mathrm{mg} / \mathrm{kg}$, and $\mathrm{mg} /$.

residual activity - the remaining amount of activity as a pesticide.

sensitizer - a delayed allergic response to a substance; symptoms usually resemble an acute toxic response.

teratogen - a compound having the property of causing birth defects

volatility - the tendency to become a vapor at relatively low temperature

\section{INFORMATION SOURCES:}

\section{U.S. Governient Agency Publications}

Pacific Northwest Region, Forest Service. U.S.

Department of Agriculture. 1988. Final

Environmental Impact Statement for Manag-

ing Competing and Unwanted Vegetation.

Chapter IV, Environmental Consequences: Human Health Effects Characterization and Management of Risk

Appendix C: Herbicide Use and Efficacy

Appendix D: Quantitative Risk Analysis

Appendix H: Qualitative Risk Analysis

Appendix J: Herbicide Review with Wildlifeoriented Effects.

Forest Service, U.S. Department of Agriculture.

1984. Pesticide Background Statements.

Volume 1. Herbicides. Agriculture Handbook

No. 663 : 
Forest Service, USDA. 1992. Risk Assessment for Herbicide Use in Forest Service Regions 1,2,3,4 and 10, and on Bonneville Power Administration Sites. Chapters III and IV.

U.S. Environmental Protection Agency, Office of Drinking Water. 1988a. Dicamba Health Advisory. $16 \mathrm{pp}$.

U.S. Environmental Protection Agency, Office of Pesticide Programs. 1983a. Guidance for the Reregistration of Pesticide Products Containing Dicamba as the Active Ingredient.

U.S. Environmental Protection Agency, Office of Pesticide Programs. 1983b. Pesticide Fact Sheet Number 8: Dicamba. 6 pp.

U.S. Environmental Protection Agency, Office of Pesticides and Toxic Substances. 1987. Letter to Dr. James S. Fickle, Sandoz Corporation re: Banvel ${ }^{\circledR}$ Dicamba Technical Herbicide (One-Year Dog Study). 2 pp.

U.S. Environmental Protection Agency, Office of Pesticides and Toxic Substances. 1989. Letter to Dr. James S. Fickle, Sandoz Corporation re: Dicamba Technical (Mouse Chronic Feeding/Oncogenicity Study and 21-Day Dermal). 3 pp.

U.S. Environmental Protection Agency. Office of Prevention, Pesticides, and Toxic Substances. 1992. EPA Pesticides in Groundwater Database, National Summary. pp. NS 105-106.

U.S. Environmental Protection Agency, Office of Prevention, Pessticides, and Toxic Substances. 1993a. Dicamba Independent Method Validation. $2 \mathrm{pp}$.

U.S. Environmental Protection Agency, Office of Prevention, Pesticides, and Toxic Substances. 1993b. Letter to Dr. Jonathan Bryant. Sandoz Corporation re: Dicamba: Review of Developmental Toxicity Study in Rabbits. 4 pp.
U.S. Environmental Protection Agency, Office of Prevention, Pesticides, and Toxic Substances. 1993c. Letter to Dr. Jonathan Bryant, Sandoz Corporation re: Dicamba Acute Neurotoxicity Study in Rats Review. 4 pp.

\section{Sandoz Publications}

Product Labels: Banvel ${ }^{\circledR}$, 1991; Vanquish ${ }^{\circledR}$, 1992. Material Safety Data Sheets: Banvel ${ }^{\circledR}$, 1989; Banvel $^{\circledR}$ CST, 1993; Vanquish ${ }^{\circledR}, 1992$.

Arnold, D. 1993. Technical Dicamba: 2-Generation Reproduction Study in Rats. Sandoz Agro Inc. Inter-office Correspondence. 2 pp.

\section{Other Sources}

American Conference of Governmental Industrial Hygienists, Inc. 1991. Documentation of the Threshold Limit Values and Biological Exposure Indices. ACGIH, Inc. Cincinnati, OH. pp. 612-613.

Arjmand, M., Spittler, T.D., Mumma, R.O. 1988. Analysis of Dicamba from Water Using Solid-Phase Extraction and Ion-Pair HighPerformance Liquid Chromatography. J. Agric. Food Chem. 36. pp. 492-494.

Beasley, V., Amold, E., Lovell, R. 1991. 2.4-D Toxicosis I: A Pilot Study of 2.4Dichlorophenoxyacetic Acid-and DicambaInduced Myotonia in Experimental Dogs. Vet. Hum. Toxicol. 33 (5). pp. 435-440.

Comfort, S., Inskeep, W., and Macur, R. 1992. Degradation and Transport of Dicamba in a Clay Soil. Journal of Environmental Quality 21:653-658.

Draper, W., and Street, J. 1982. Applicator Exposure to 2,4-D. Dicamba, and a Dicamba Isomer. J. Environ. Sci. Health, B 17(4), 321339.

Gaines, T. and Linder, R. 1986. Acute Toxicity of Pesticides in Adult and Weanling Rats.

Fundamental and Applied Toxicology 7, 299308. 
Hamman, R. and Kettrup, A. 1987. Determination of Phenoxy Acid Herbicides in Water Samples. Chemosphere 16 (2/3). pp. 527536.

Hoffman, D.J., Albers, P.H. 1984. Evaluation of Potential Embryotoxicity and Teratogenicity of 42 Herbicides, Insecticides, and Petroleum Contaminants to Mallard Eggs. Archives of Environmental Contamination and Toxicology 13:15-27.

Huff, J., Cirvello, J., Haseman, J., and Bucher, J. 1991. Chemicals Associated with Site-Specific Neoplasia in 1394 Long-Term Carcinogenesis Experiments in Laboratory Rodents. Environmental Health Perspectives (in press).

Jimenez, N.C., Atallah, Y.H., and Bade, T.R. 1989. Capillary Column Gas Chromatographic Determination of Dicamba in Water. Including Mass Spectrometric Confirmation. J. Assoc. Off. Anal. Chem. 72 (5). pp. 840844.

Kutz, F., Cook, B., Carter-Pokras, O., Brody, D., Murphy, R. 1992. Selected Pesticide Resi-. dues and Metabolites in Urine from a. Survey of the U.S. General Population. Journal of Toxicology and Environmental Health, -37:277-291.

Ma, T., Harris, M., Anderson, V., Ahmed, I.. Mohammad, K., Bare, J., and Lin, G. 1984. Tradescantia Micronucleus Tests on 140 Health-related Agents.

Mayer, J., and Elkins, N. 1990. Potential for Agricultural Pesticide Runoff to a Puget Sound Estuary: Padilla Bay, Washington. Bull. Environ. Contam. Toxicol. 45:215-222.
Moody, D., Narloch, B., Shull, L., and Hammock, B. 1991. The Effect of Structurally Divergent Herbicides on Mouse Liver Xenobiotic-metabolizing Enzymes and Carnitine Acetyltransferase. Toxicology Letters 59:175-185.

Potter, W., Garry, V.,-Kelly, J., Tarone, R., Griffith, J., and Nelson, R. 1993. Radiometric Assay of Red Cell and Plasma Cholinesterase in Pesticide Appliers from Minnesota. Toxicol. Appl. Pharmacol. 119, 150-155.

Westra, P. and Schwartz, H. 1989. Potential Herbicide Volatility and Drift Problems on Dry Beans. Colorado State University Cooperative Extension "Service in Action" No. 2.803 . 


\section{Toxicity and Risk Categories}

Estimates of Health Risks to the Public and TO WORKERS From Forest SERVICE OpERations

The FEIS predicts levels of human exposure (dose) for project workers and for the public, for both a typical field project and for a large accidental spill. These dose levels are compared to the highest dose level in animal tests that showed no health effect (No Observed Effects Level). The risk is ranked from "Negligible" to "High" based on the margin between the expected human dose and the highest NOEL_"no effect" dose. A "High"'risk rating means that the highest NOEL dose is not more than ten times larger than predicted human dose under the specified conditions. A "Moderate" risk rating means that the highest NOEL dose is between 10 and 100 times larger than the expected human dose.

\begin{tabular}{|c|c|c|}
\hline \multicolumn{3}{|c|}{ Estimated Health Risks } \\
To The Public \\
\hline Situation & General Health & Reproduction \\
\hline $\begin{array}{c}\text { Routine Large } \\
\text { Aerial Application }\end{array}$ & Low & Moderate \\
\hline $\begin{array}{c}\text { Routine } \\
\text { Application- } \\
\text { Other }\end{array}$ & Negligible & Negligible \\
\hline Large Spill & Moderate & High \\
\hline
\end{tabular}

\begin{tabular}{|c|c|c|}
\hline \multicolumn{3}{|c|}{$\begin{array}{c}\text { Estimated Health Risks } \\
\text { to Project Workers }\end{array}$} \\
\hline Worker & General Health & Reproduction \\
\hline $\begin{array}{c}\text { Aerial } \\
\text { Mixer/Loader }\end{array}$ & Low & Low \\
\hline $\begin{array}{c}\text { Backpack } \\
\text { Sprayer }\end{array}$ & Low & Moderate \\
\hline $\begin{array}{c}\text { Right-of-way } \\
\text { Mixer/Loader }\end{array}$ & Negligible & Negligible \\
\hline $\begin{array}{c}\text { Hack-and- } \\
\text { Squirt }\end{array}$ & Low & Moderate \\
\hline
\end{tabular}

\section{Ecotoxological Categories}

\begin{tabular}{|c|c|}
\hline \multicolumn{2}{|c|}{ Mammalian (Acute Oral): } \\
\hline$m g / k g$ & Risk Category \\
\hline$<10$ & very highly toxic \\
\hline $10-50$ & highly toxic \\
\hline $51-500$ & moderately toxic \\
\hline $501-2000$ & slightly toxic \\
\hline$>2000$ & practically non toxic \\
\hline
\end{tabular}

\begin{tabular}{|c|c|}
\hline \multicolumn{2}{|c|}{ Avian (Acute Oral): } \\
\hline$m g / k g$ & Risk Category \\
\hline$<10$ & very highly toxic \\
\hline $10-50$ & highly toxic \\
\hline $51-500$ & moderately toxic \\
\hline $501-2000$ & slightly toxic \\
\hline$>2000$ & practically non toxic \\
\hline
\end{tabular}

\begin{tabular}{|c|c|}
\hline \multicolumn{2}{|c|}{ Avian (Dietary): } \\
\hline$m g / k g$ & Risk Category \\
\hline$<50$ & very highly toxic \\
\hline $50-500$ & highly toxic \\
\hline $501-1000$ & moderately toxic \\
\hline $1001-5000$ & slightly toxic \\
\hline$>50 \times 0$ & practically non toxic \\
\hline
\end{tabular}

\begin{tabular}{|c|c|}
\hline \multicolumn{2}{|c|}{ Aquatic: } \\
\hline$p p m$ & Risk Category \\
\hline$<0.1$ & very highly toxic \\
\hline $0.1-1$ & highly toxic \\
\hline$>1-10$ & moderately toxic \\
\hline$>10-100$ & slightly toxic \\
\hline$>100$ & practically non toxic \\
\hline
\end{tabular}




\section{Tables of Categories of ToxicIty}

\begin{tabular}{|c|c|c|c|c|}
\hline \multicolumn{5}{|c|}{ Human Hazards } \\
\hline & & \multicolumn{2}{c|}{ Route of Administration } \\
\hline Risk Category & Signal Word & $\begin{array}{c}\text { Oral } \\
(\mathbf{m g} / \mathbf{k g})\end{array}$ & Dermal (mg/kg) & $\begin{array}{c}\text { Inhalation } \\
(\mathbf{m g} / \mathrm{kg})\end{array}$ \\
\hline I & DANGER-Poison & $0-50$ & $0-200$ & $0-0.2$ \\
\hline II & WARNING & $>50-500$ & $>200-2000$ & $>0.2-2.0$ \\
\hline III & CAUTION & $>500-5000$ & $>2000-20,000$ & $>2.0-20$ \\
\hline IV & NONE & $>5000$ & $>20,000$ & $>20$ \\
\hline
\end{tabular}

\begin{tabular}{|c|c|c|}
\cline { 2 - 3 } \multicolumn{1}{c|}{} & \multicolumn{2}{c|}{ Hazard } \\
\hline Category & Eye Irritation & Skin Irritation \\
\hline I & $\begin{array}{c}\text { Corrosive: corneal opacity not reversible } \\
\text { within 7 days }\end{array}$ & corrosive \\
\hline II & $\begin{array}{c}\text { corneal opacity reversible within 7 daýs; } \\
\text { irritation persisting for 7 days }\end{array}$ & severe irritation at 72 hours \\
\hline III & $\begin{array}{c}\text { no comeal opacity; } \\
\text { irritation reversible within 7 days }\end{array}$ & moderate irritation at 72 hours \\
\hline IV & no irritation & mild or slight irritation at 72 hours \\
\hline
\end{tabular}

\section{Categories of Quality of Health Effects Data}

\begin{tabular}{|l|l|}
\hline Inadequate: & $\begin{array}{l}\text { Inadequate information available for evaluating toxicity. There were too few studies of } \\
\text { sufficient quality to yicld useful or reliable information. }\end{array}$ \\
\hline $\begin{array}{l}\text { Marginal- } \\
\text { Inadequate: }\end{array}$ & $\begin{array}{l}\text { Some useful information exists for evaluating toxicity. There were studies of marginal } \\
\text { quality that provided useful information, but studies, were inconsistent and some contained } \\
\text { flaws. It is likely that new studies would change estimates of health effects. }\end{array}$ \\
\hline Marginal: & $\begin{array}{l}\text { Marginal but useful information available for evaluating toxicity. There were studies of } \\
\text { adequate quality, and results did not vary greatly, but more information would increase } \\
\text { reliability. Although new studies may changc estimates of health effects, the results are } \\
\text { considered moderately reliable. }\end{array}$ \\
\hline Adequate: & $\begin{array}{l}\text { Adequate information is available. Studies are of sufficient quality and quantity that } \\
\text { estimates of human health are considered reliable. New studies are unlikely to change } \\
\text { estimates of health effects. }\end{array}$ \\
\hline
\end{tabular}

